Prepared in cooperation with the Missouri River Recovery Program

\title{
Science Information to Support Missouri River Scaphirhynchus albus (Pallid Sturgeon) Effects Analysis
}

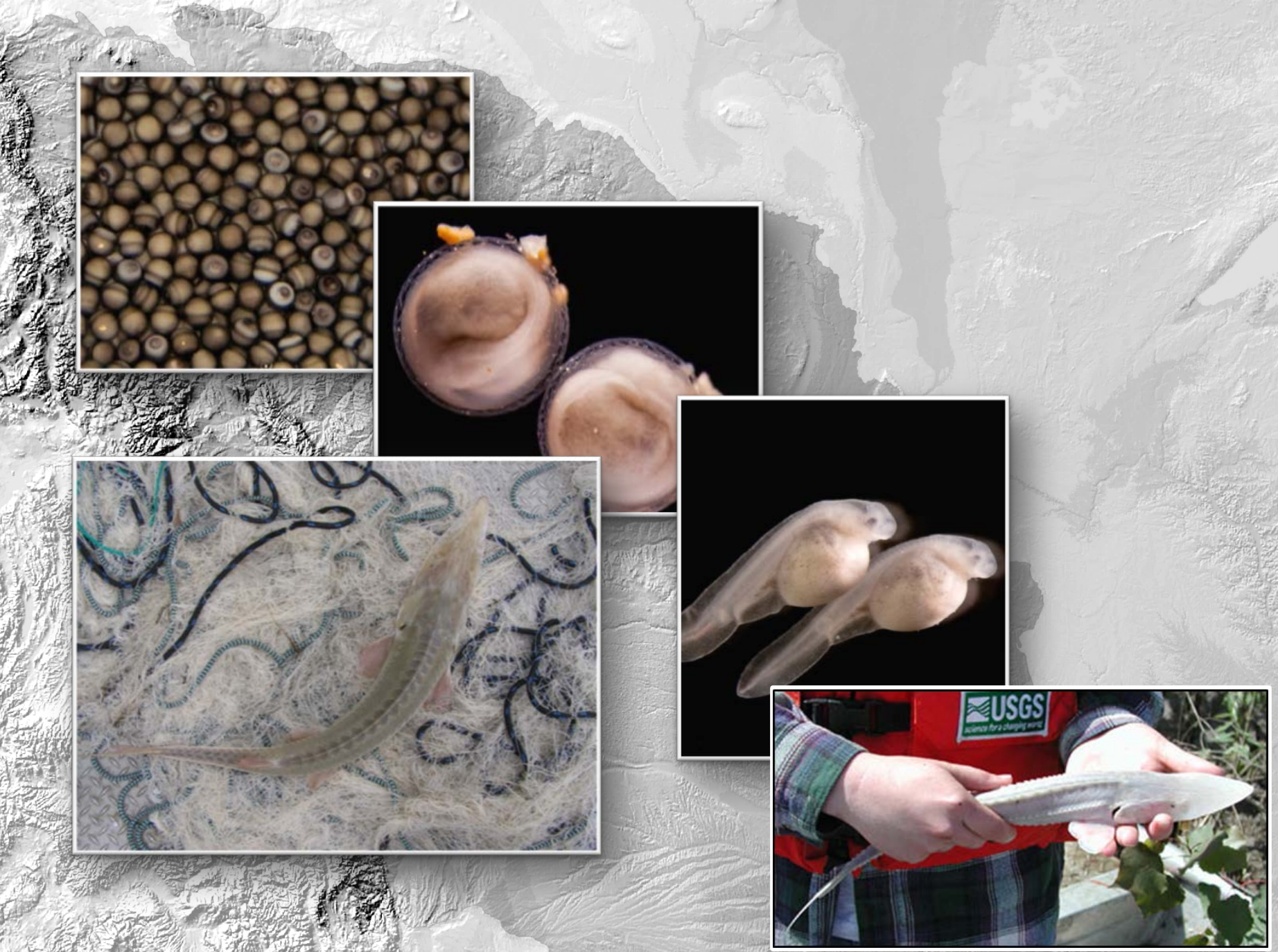

Open-File Report 2015-1226

U.S. Department of the Interior U.S. Geological Survey 
Cover photograph index:

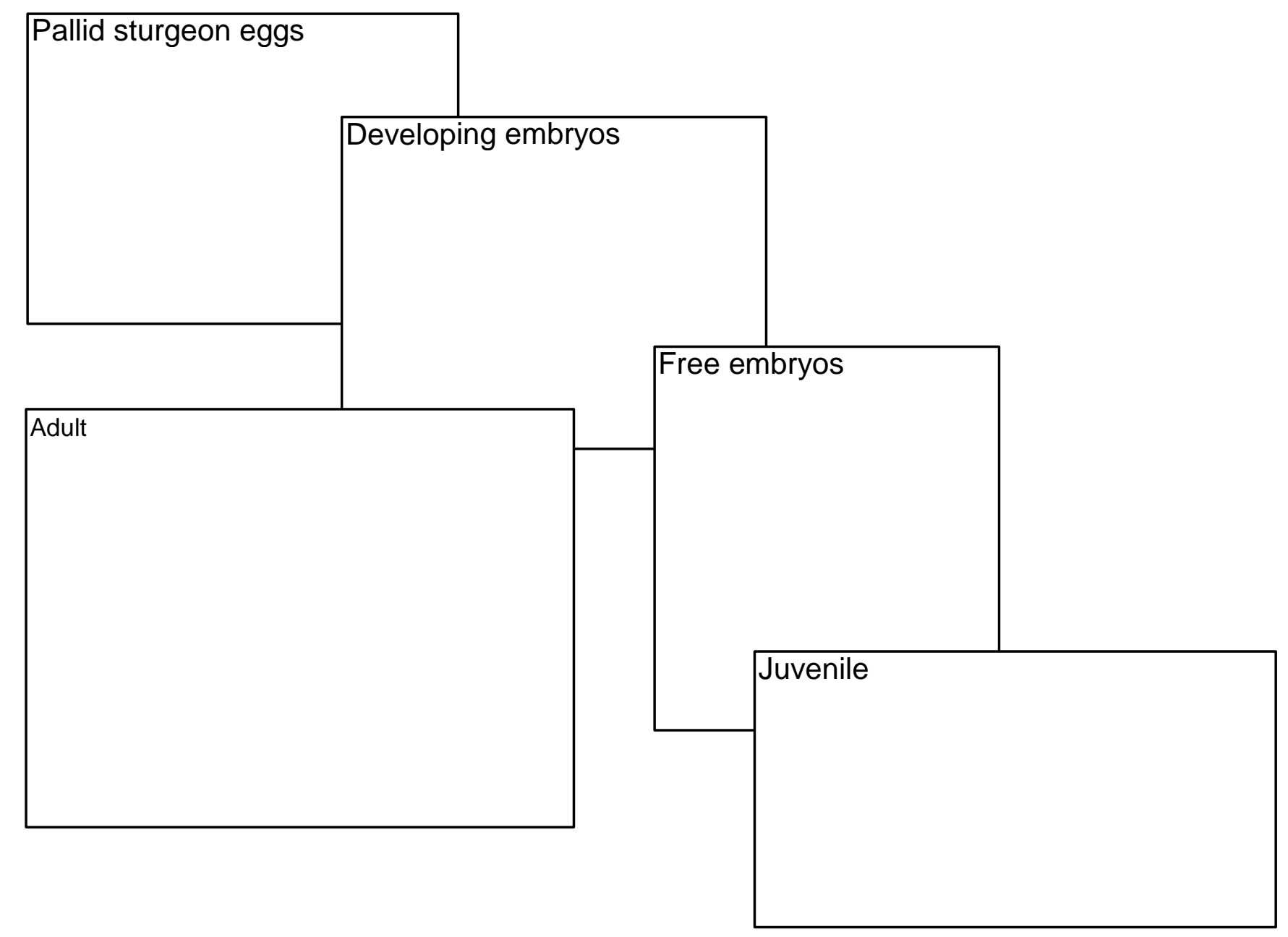

Background image: shaded relief map of the Missouri River drainage basin, U.S. Geological Survey, EROS Data Center.

Photographs by U.S. Geological Survey personnel 


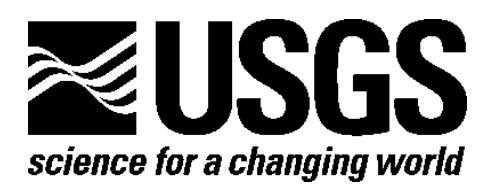

Prepared in cooperation with the Missouri River Recovery Program

\section{Science Information to Support Missouri River Scaphirhynchus albus (Pallid Sturgeon) Effects Analysis}

By Robert B. Jacobson, Michael J. Parsley, Mandy L. Annis, Michael E. Colvin, Timothy L. Welker, and Daniel A. James

Open-File Report 2015-1226

U.S. Department of the Interior

U.S. Geological Survey 


\title{
U.S. Department of the Interior SALLY JEWELL, Secretary
}

\section{U.S. Geological Survey \\ Suzette M. Kimball, Director}

\author{
U.S. Geological Survey, Reston: Virginia 2015
}

For more information on the USGS-the Federal source for science about the Earth, its natural and living resources, natural hazards, and the environment-visit http://www.usgs.gov/ or call 1-888ASK-USGS (1-888-275-8747).

For an overview of USGS information products, including maps, imagery, and publications, visit http://www.usgs.gov/pubprod

Any use of trade, product, or firm names is for descriptive purposes only and does not imply endorsement by the U.S. Government.

Although this information product, for the most part, is in the public domain, it also may contain copyrighted materials as noted in the text. Permission to reproduce copyrighted items must be secured from the copyright owner.

\footnotetext{
Suggested citation:

Jacobson, R.B., Parsley, M.J., Annis, M.L., Colvin, M.E., Welker, T.L., and James, D.A., 2015, Science information to support Missouri River Scaphirhynchus albus (pallid sturgeon) effects analysis: U.S. Geological Survey Open-File Report 2015-1226, 78 p., http://dx.doi.org/10.3133/ofr20151226.
}

ISSN 2331-1258 (online) 


\section{Contents}

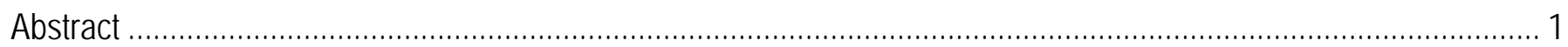

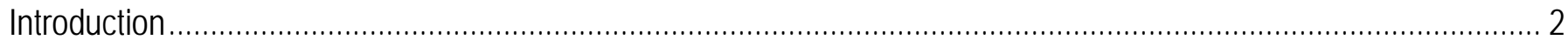

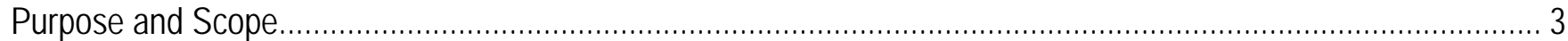

State of Knowledge - Pallid Sturgeon Literature Review .............................................................................. 3

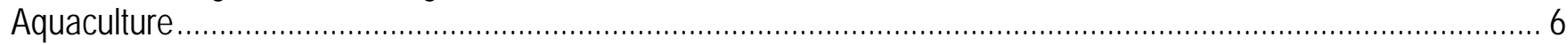

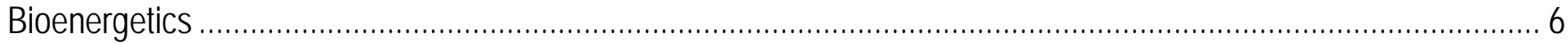

Diet.

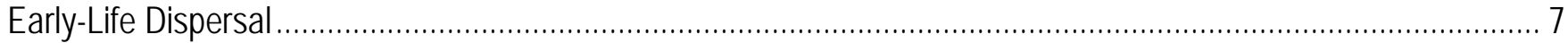

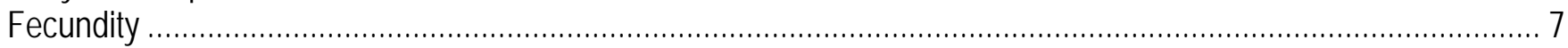

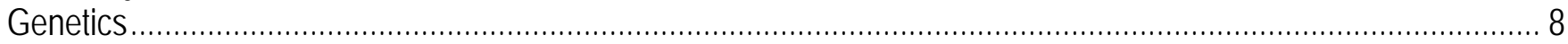

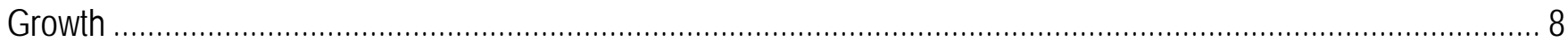

Habitat

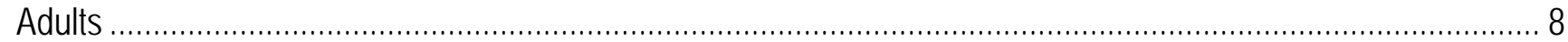

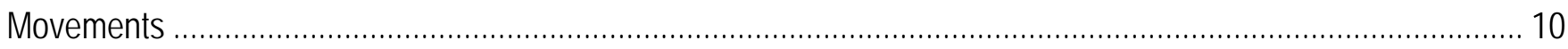

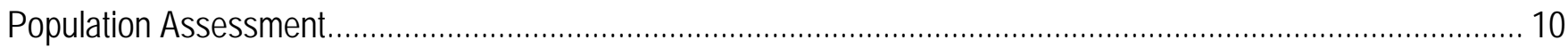

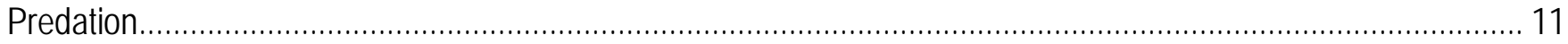

Recruitment

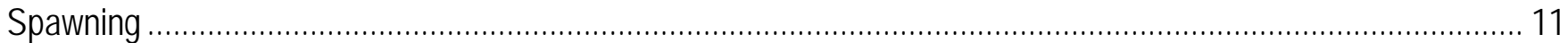

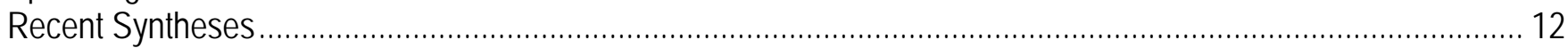

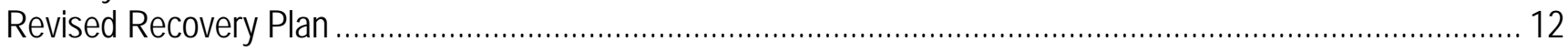

Ecological Requirements for Pallid Sturgeon Reproduction and Recruitment in the Missouri River: A Synthesis of Science, 2005-12 ............................................................................................................ 13

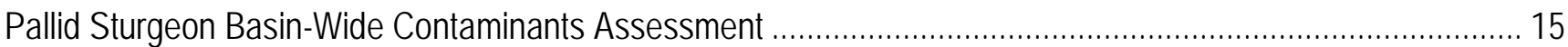

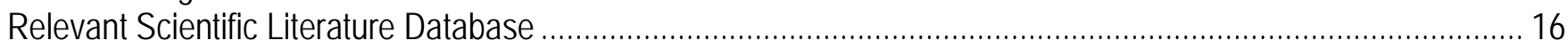

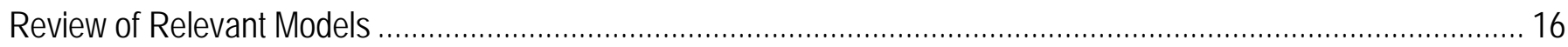

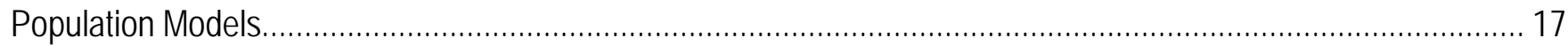

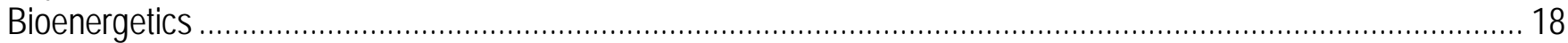

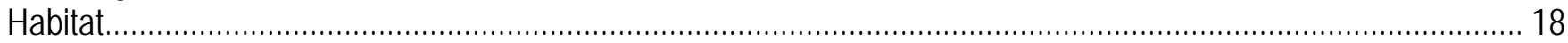

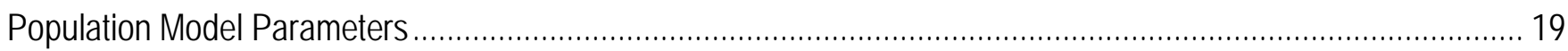

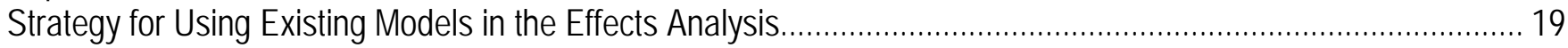

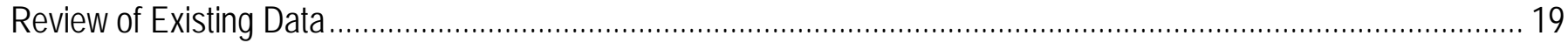

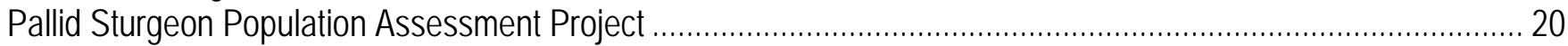

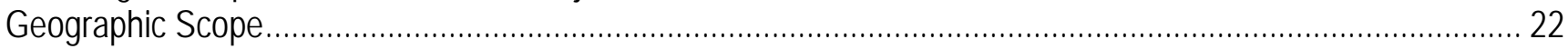

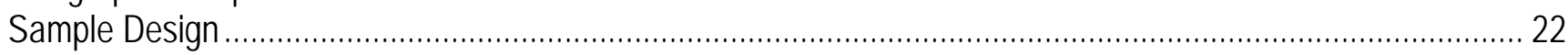

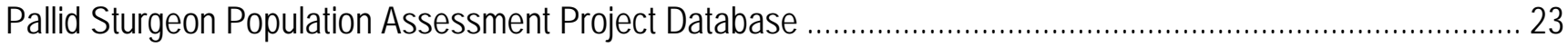

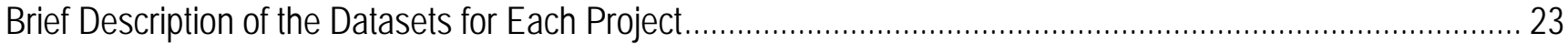

Project 1-Pallid Sturgeon Population Assessment Project .................................................................. 23

Project 2-Habitat and Assessment Monitoring Project.................................................................... 23

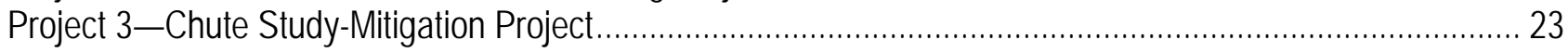

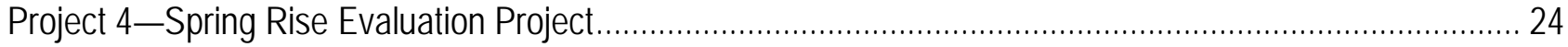

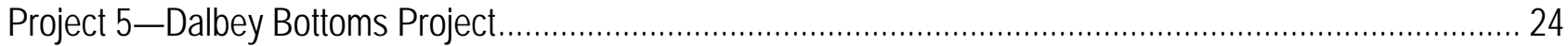

Project 6_Pallid Sturgeon Catchability Project ................................................................................ 24

Evaluation and Contribution to Effects Analysis .................................................................................. 24

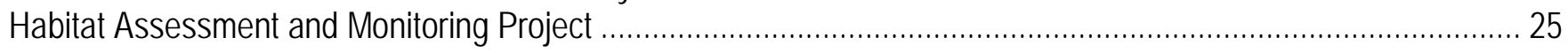




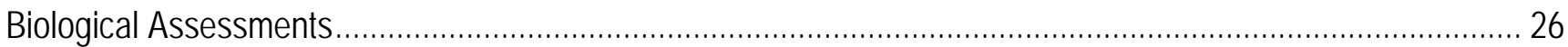

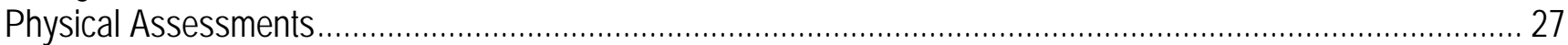

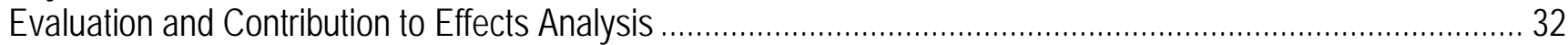

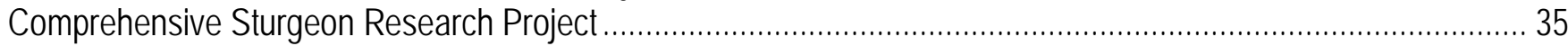

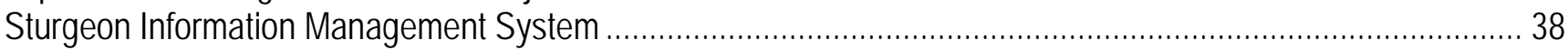

Missouri River Hydroacoustic Habitat Dynamics System (MRHHDS) ………............................................ 42

Missouri River Hydroacoustic Habitat Dynamics System Holdings 2005-13 .............................................. 45

Evaluation and Contribution to Effects Analysis ................................................................................ 47

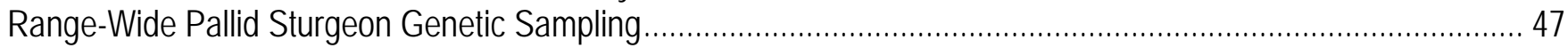

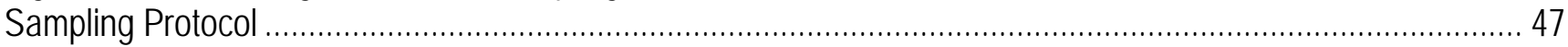

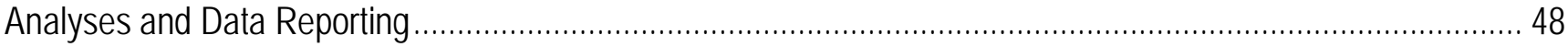

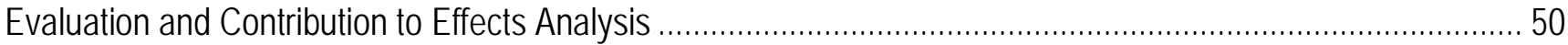

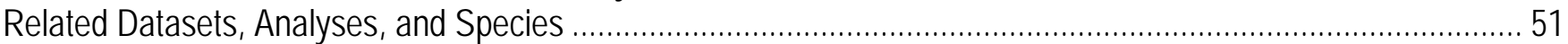

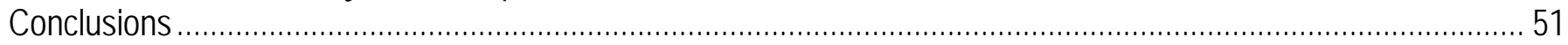

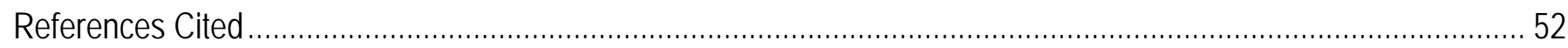

Appendix A. The Effects of Missouri River Basin Contaminants on Scaphirhynchus Sturgeon-A Summary of

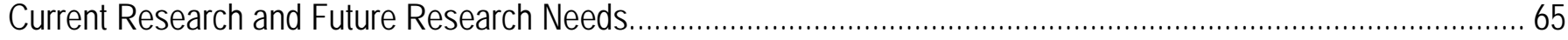

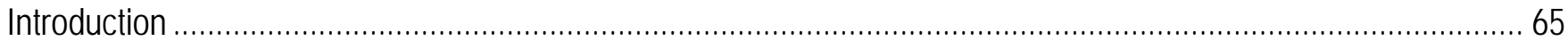

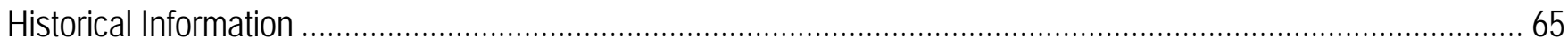

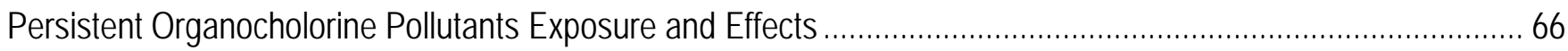

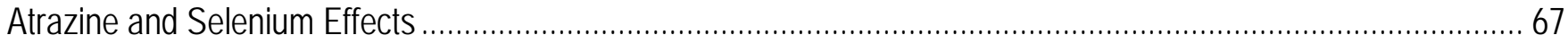

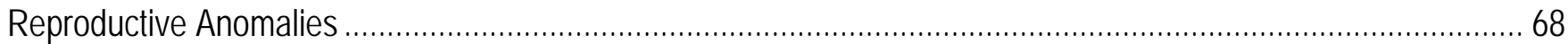

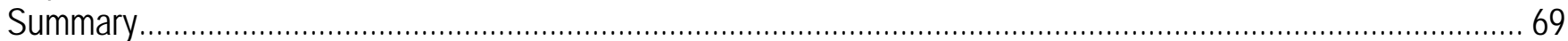

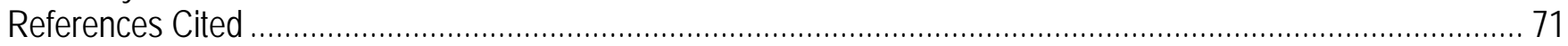

Appendix B. Database Fields and Descriptions for the Pallid Sturgeon Population Assessment Project.................... 75

\section{Figures}

Figure 1. Maps showing A, historical and B, current (2015) range of Scaphirhynchus albus (pallid sturgeon). 4

Figure 2. Graphs showing summaries of peer-reviewed literature on Scaphirhynchus albus (pallid sturgeon), 1992 through May 2014

Figure 3. Map showing sampled segments of the Missouri River for the Pallid Sturgeon Population Assessment Project, 2014.

Figure 4. Diagram showing the three-tiered hierarchical habitat classification system utilized by the Pallid Sturgeon Population Assessment Project. ...................................................................................... 22

Figure 5. Map showing river miles for the Missouri River main stem. ........................................................... 28

Figure 6. Map showing the four segments researched by the Comprehensive Sturgeon Research Project....... 36

Figure 7. Diagram showing overview of Sturgeon Information Management System used to collect, manage, integrate, and explore data for the Comprehensive Sturgeon Research Project. 


\section{Tables}

Table 1. Scaphirhynchus albus (pallid sturgeon) and Scaphirhynchus platorynchus (shovelnose sturgeon) population models identified

Table 2. River bends sampled in the Missouri River and selected tributaries for the Pallid Sturgeon Population Assessment Project, 2003-14.

Table 3. Graph of the number of subsamples for each project housed in the Pallid Sturgeon Population Assessment Database

Table 4. List of datasets for physical-habitat surveys that have been conducted as part of the Habitat Assessment and Monitoring Program in the main channel of the Kansas City District Missouri River

Table 5. List of datasets for physical habitat surveys that have been conducted as part of the Habitat Assessment and Monitoring Program in chute habitats of the Kansas City District Missouri River.

Table 6. List of datasets for two-dimensional modeling surveys that have been conducted as part of the Habitat Assessment and Monitoring Program in the Kansas City District Missouri River

Table 7. List of datasets for physical habitat surveys that have been conducted as part of the Habitat Assessment and Monitoring Program in the Omaha district Missouri River

Table 8. Description of primary datasets collected and maintained by the Sturgeon Information Management System for the Comprehensive Sturgeon Research Project

Table 9. Summary of the number of pallid sturgeon implanted with telemetry devices, number tracked, locations recorded, reimplanted with telemetry devices, and reproductive evaluations, in the Lower Missouri River; 20052013.

Table 10. Summary of the number of shovelnose sturgeon implanted with telemetry devices, tracked, intensively tracked, telemetry locations recorded, and number recaptured per year in the Lower Missouri River; 20052008.

Table 11. Summary of the number of pallid sturgeon telemetry locations recorded, and number of unique telemetry codes recorded per year in the Upper Missouri River; 2011-2013.

Table 12. Map product types and areas mapped by year and data category for Missouri River and tributary reaches..

Table 13. Non-reach map hydroacoustic data collections for the Missouri River and tributaries

Table 14. Reach-scale hydroacoustic maps by geographic Missouri and Yellowstone River segment ............... 44

Table 15. Summary of pallid sturgeon genetic sample processing, as of September 2014 …............................. 48

Table B.1 Datasheets for Missouri River (habitat), fish, and supplemental information...................................... 75 


\section{Conversion Factors}

Inch/Pound to International System of Units

\begin{tabular}{lcl}
\hline \multicolumn{1}{c}{ Multiply } & By & \multicolumn{1}{c}{ To obtain } \\
\hline foot $(\mathrm{ft})$ & Length & \\
mile $(\mathrm{mi})$ & 0.3048 & meter $(\mathrm{m})$ \\
\hline & 1.609 & kilometer $(\mathrm{km})$ \\
\hline foot per second $(\mathrm{ft} / \mathrm{s})$ & Flow rate & \\
cubic foot per second $\left(\mathrm{ft}^{3} / \mathrm{s}\right)$ & 0.3048 & meter per second $(\mathrm{m} / \mathrm{s})$ \\
\hline
\end{tabular}

International System of Units to Inch/Pound

\begin{tabular}{lcl}
\hline & Multiply & By obtain \\
\hline meter $(\mathrm{m})$ & Length & \\
kilometer $(\mathrm{km})$ & 3.281 & foot $(\mathrm{ft})$ \\
& 0.6214 & mile $(\mathrm{mi})$ \\
\hline meter per second $(\mathrm{m} / \mathrm{s})$ & Flow rate & \\
cubic meter per second $\left(\mathrm{m}^{3} / \mathrm{s}\right)$ & 3.281 & foot per second $(\mathrm{ft} / \mathrm{s})$ \\
\hline & 35.31 & cubic foot per second $\left(\mathrm{ft}^{3} / \mathrm{s}\right)$ \\
\hline gram $(\mathrm{g})$ & Mass & \\
\hline
\end{tabular}

To communicate effectively with stakeholders, managers, and other scientists working on the Lower Missouri River, this report uses a mix of U.S. customary units and International System of Units (SI) units of measure. Distances along the Missouri River are given in river miles upstream from the junction with the Mississippi River at St. Louis, Missouri, as measured by the U.S. Army Corps of Engineers in 1960. Discharges are provided in the customary units of cubic feet per second. Reach-scale hydraulic variables-depth and velocity —are in SI units of meters and meters per second.

Temperature in degrees Celsius $\left({ }^{\circ} \mathrm{C}\right)$ may be converted to degrees Fahrenheit $\left({ }^{\circ} \mathrm{F}\right)$ as follows:

${ }^{\circ} \mathrm{F}=\left(1.8 \times{ }^{\circ} \mathrm{C}\right)+32$

\section{Datum}

Vertical coordinate information is referenced to the North American Vertical Datum of 1988 (NAVD 88).

Horizontal coordinate information is referenced to the World Geodetic System of 1984 (WGS 84). 


\title{
Science Information to Support Missouri River Scaphirhynchus albus (Pallid Sturgeon) Effects Analysis
}

By Robert B. Jacobson ${ }^{1}$, Michael J. Parsley², Mandy L. Annis ${ }^{1}$, Michael E. Colvin ${ }^{3}$, Timothy L. Welker ${ }^{4}$, and Daniel A. James ${ }^{5}$

\begin{abstract}
The Missouri River Pallid Sturgeon Effects Analysis (EA) was commissioned by the U.S. Army Corps of Engineers to develop a foundation of understanding of how pallid sturgeon (Scaphirhynchus albus) population dynamics are linked to management actions in the Missouri River. The EA consists of several steps: (1) development of comprehensive, conceptual ecological models illustrating pallid sturgeon population dynamics and links to management actions and other drivers; (2) compilation and assessment of available scientific literature, databases, and models; (3) development of predictive, quantitative models to explore the system dynamics and population responses to management actions; and (4) analysis and assessment of effects of system operations and actions on species' habitats and populations. This report addresses the second objective, compilation and assessment of relevant information.

Scientific information on pallid sturgeon and its environment has grown substantially during the last decade. Presently available (2015) information indicates that stocked sturgeon are surviving and growing, and that wild and hatchery sturgeon are spawning in the wild. However, natural recruitment to age-1 and older has not been detected since systematic sampling began in 2005. Population models indicate the sensitivity of population growth to certain demographic variables, in particular early-life stage survival and perhaps adult fecundity. This report documents the existing population models for the pallid sturgeon, and the substantial quantities of information developed through the Pallid Sturgeon Population Assessment Program (PSPAP), the Habitat Assessment and Monitoring Program (HAMP), the Comprehensive Sturgeon Research Project (CSRP), range-wide genetics databases, and related research studies. The reference database compiled for the EA consists of over 190 peer-reviewed documents specifically related to pallid sturgeon and over 12,000 references on the Missouri River system and related species.

Notwithstanding the large quantity of information available, the EA faces challenges in synthesizing the information into useful, quantitative models. In particular, critical demographic parameters for population models remain uncertain and the functional relationships between the two main categories of physical management action-changes in flow regime and reengineering channel form - and pallid sturgeon survival responses are obscure. In addition, there is an overarching uncertainty about how physical management actions interact with propagation management actions in

\footnotetext{
${ }^{1}$ U.S. Geological Survey

${ }^{2}$ U.S. Geological Survey (retired)

${ }^{3}$ Oregon State University and Mississippi State University

${ }^{4}$ U.S. Army Corps of Engineers

${ }^{5}$ U.S. Fish and Wildlife Service
} 
view of evolving understanding of genetic structuring of the pallid sturgeon population. Synthesis efforts are also challenged by the fragmentation of information sources among projects and agencies; one objective of this report is to facilitate future assessments by providing documentation of what information is available and where.

\section{Introduction}

The U.S. Army Corps of Engineers (USACE) and the U.S. Fish and Wildlife Service (USFWS) initiated an Effects Analysis (EA) for the Missouri River Recovery Program (MRRP) in October 2013. The EA was encouraged by the Missouri River Recovery Implementation Committee (MRRIC) and the MRRIC Independent Science Advisory Panel (ISAP) as a means to review recovery progress, provide quantitative models relating endangered species’ responses to management actions, provide a foundation for structured decisionmaking, and to create a framework for continued monitoring and assessment through adaptive management. As formulated under the Endangered Species Act of 1973 (16 U.S.C. ch. $35 \S 1531$ ) (ESA), an effects analysis evaluates proposed actions taken by a Federal agency on a listed species or critical habitat (Murphy and Weiland, 2011). The guidance document for the Missouri River EA states:

The Effects Analysis proposed here will inform current AM (adaptive management) efforts and several key portions of the Management Plan and its future implementation within an adaptive management framework including, but not limited to: refining CEMs (conceptual ecological models) to guide quantitative models, providing tools to inform setting quantitative targets for species objectives, compiling and assessing existing data and modeling resources, analyzing and assessing pertinent scientific and operational information to identify the effects of system operations and actions on species populations and their habitats, and developing quantitative models that can be used for forecasting the effect of different alternatives on listed species performance.

The EA serves as a punctuation in MRRP progress, allowing for evaluation of program effectiveness and recalibration of some program activities, particularly those related to science efforts to support adaptive management. In general, an effects analysis consists of several distinct steps (Murphy and Weiland, 2011); the EA guidance document describes the four that are the responsibility of this EA:

1. Development of comprehensive CEMs that document beliefs of how species’ population dynamics are linked to the river system and how it is managed;

2. Compilation of available scientific literature, databases, and models and assessment of how well existing information may be used to support the effects analysis;

3. Development of predictive, quantitative versions of the conceptual models to explore the relationships and responses of system, actions and species;

4. Analysis and assessment of effects of system operations and actions on species' populations and their habitats.

The first of these-development of CEMs_-has been completed. The present document is intended to satisfy step 2 by providing a compilation and assessment of available information, databases, and models with relevance to understanding population dynamics of Scaphirhynchus albus (pallid sturgeon) in the Missouri River Basin.

The pallid sturgeon EA is structured to provide information to address the fundamental species objective developed by the U.S. Fish and Wildlife Service: "Avoid jeopardizing the continued existence of the pallid sturgeon from U.S. Army Corps of Engineers actions on the Missouri River.” (Casey 
Kruse, U.S. Fish and Wildlife Service, written commun., 2013). The fundamental species objectives are accompanied by sub-objectives that are measurable and relevant:

- $\quad$ Sub-objective 1-Increase pallid sturgeon recruitment to age-1,

- $\quad$ Sub-objective 2-Maintain or increase numbers of pallid sturgeon as an interim measure until sufficient and sustained natural recruitment occurs.

The emphasis on recruitment reflects the fact that in the Missouri River no genetically determined, successful recruitment of wild pallid sturgeon to age-1 has been detected over the last 20 years (U.S. Fish and Wildlife Service, 2014).

\section{Purpose and Scope}

This report is intended to describe and provide an initial assessment of information available to serve as a foundation for the EA. This report is one of a series of documents emanating from the EA that document the process of reasoning from CEMs to working hypotheses, to a quantitative modeling structure for the effects of Missouri River management actions on pallid sturgeon population dynamics. The report is organized in sections that review the general state of the science for Missouri River pallid sturgeon. We compiled the existing scientific literature, reviewed models that address key life-history processes and population dynamics, and examined historic and contemporary existing datasets for use in the EA. The EA will require integration of biological information with hydrological and abiotic data, and while this report focuses primarily on information pertaining to pallid sturgeon biology, ecology, and life history, we also considered the availability and adequacy of existing hydrological, hydraulic, water quality, and physical data deemed necessary for use.

The geographic scope of the EA includes parts of the Missouri River, tributaries, and Mississippi River that contribute to population dynamics of Missouri River pallid sturgeon (fig. 1.) Presently, the reservoirs and inter-reservoir reaches are omitted from the analysis due to the perception that they have low potential for contributing to recovery of the species. The Upper Missouri River between Lake Sakakawea and Fort Peck Dam and the Lower Yellowstone River from the confluence with the Upper Missouri River to near Forsyth, Montana, are also included (fig. 1). For simplicity, we refer to the Upper Missouri River and the lower reaches of the Yellowstone River as the upper river. We refer to the Lower Missouri River, tributaries used by the pallid sturgeon, and part of the Mississippi River downstream from the Missouri River confluence as the lower river.

The scope of information to apply to the EA is not limited by geography or species as understanding of biology of other sturgeon species and other rivers can contribute to understanding of the pallid sturgeon. The degree to which information is extrapolated from other species and other rivers is taken into account in assessing data quality.

\section{State of Knowledge - Pallid Sturgeon Literature Review}

Research, monitoring, and assessment of pallid sturgeon have increased markedly since about 2000, as indicated by the number of peer-reviewed scientific publications found in a standard reference search (fig. 2). We compiled an EndNote ${ }^{\circledR}$ database with 192 peer-reviewed references representing a range of topics pertinent to pallid sturgeon. The Endnote ${ }^{\circledR}$ database includes more than 260 additional published and unpublished reports on pallid sturgeon and approximately 2,500 additional peer-reviewed articles pertaining to other sturgeon species. The content of the published and unpublished reports varies and some contain information that will be useful to the EA. The use of information from other sturgeon species and the nonpeer-reviewed reports will be considered and incorporated when appropriate. 


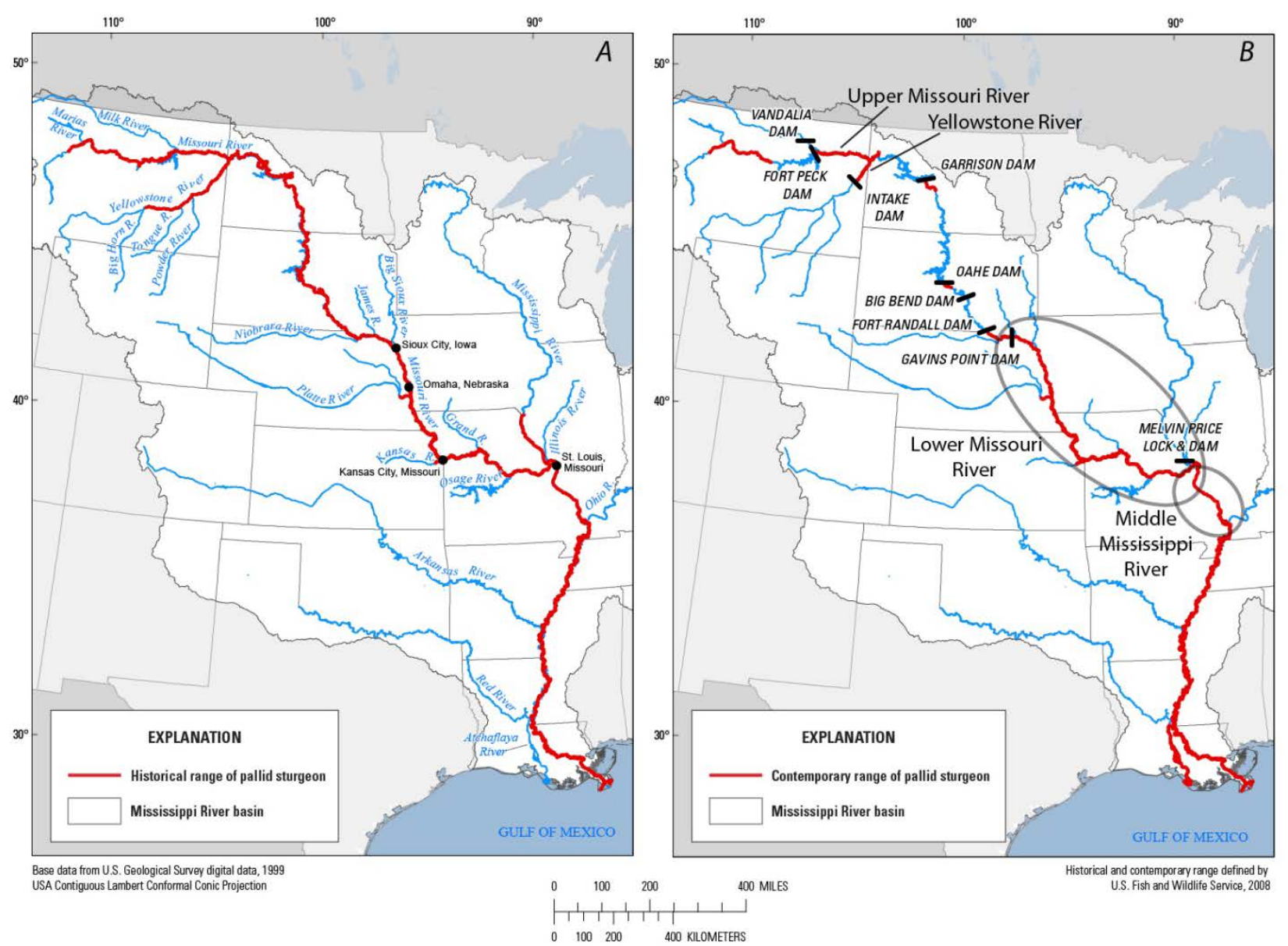

Figure 1. Maps showing A, historical and B, current (2015) range of Scaphirhynchus albus (pallid sturgeon).

The increase of scientific effort on pallid sturgeon lagged more than a decade behind the ESA listing in 1990. The increase generally coincided with the 2000 and 2003 "Missouri River Biological Opinion" and the 2004 "Missouri River Master Water Control Manual," which together called for increasing emphasis on building the scientific foundation for managing the Missouri River to promote recovery of the species (U.S. Fish and Wildlife Service, 2000, 2003; U.S. Army Corps of Engineers, 2004, 2006). Focused science efforts include the Pallid Sturgeon Population Assessment Project (PSPAP), the Habitat Assessment and Monitoring Project (HAMP), the Comprehensive Sturgeon Research Project (CSRP), and early-life stage research carried out at South Dakota State University. Direction and prioritization of pallid sturgeon science has come from multiple sources including comprehensive workshops in 2004 and 2008 (Quist and others, 2004; Bergman and others, 2008), specific project reviews (Sustainable Ecosystems Institute, 2004, 2005, 2007, 2008), results of the "spring rise” plenary group process (Jacobson and Galat, 2008), and deliberations of the Missouri River Recovery Implementation Committee (MRRIC) Independent Science Advisory Panel (ISAP) (Doyle and others, 2011).

The following sections provide reviews of published literature in the context of usefulness to the EA. We emphasize literature for which there is evidence of peer review-including journal articles, academic theses and dissertations, and some agency reports—but we also have evaluated agency reports that have not been peer reviewed or for which the peer review status is unclear. A great deal of fundamental information on pallid sturgeon reproductive ecology is contained in agency data reports and unpublished files and it would be inefficient to omit them from consideration. Topics are arranged in alphabetical order. 

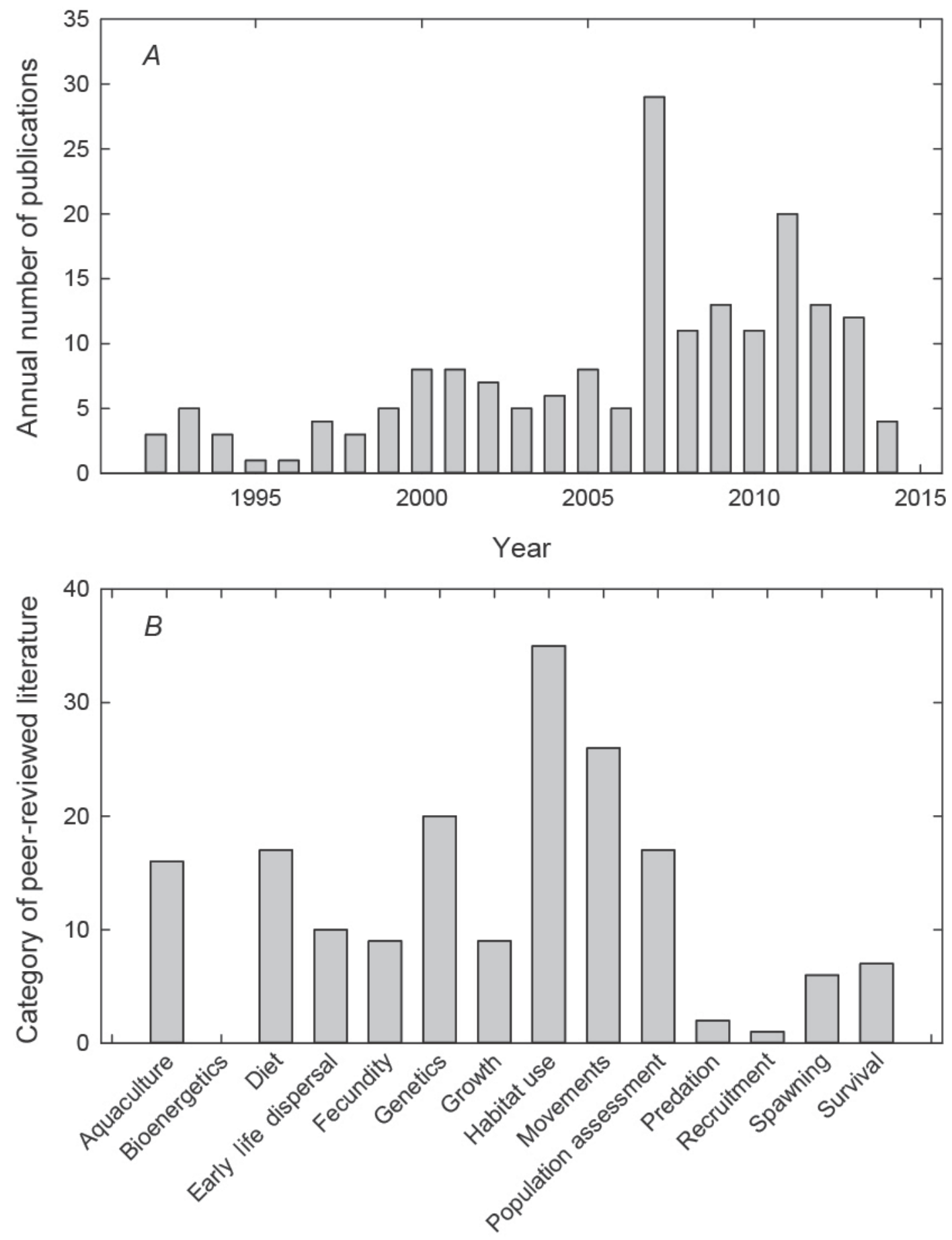

Published literature

Figure 2. Graphs showing summaries of peer-reviewed literature on Scaphirhynchus albus (pallid sturgeon), 1992 through May 2014. A, Annual number of peer-reviewed, published literature (number of articles included scientific journals, U.S. Geological Survey Scientific Investigations Reports, academic theses, and books. $B$, Number of peer-reviewed articles on pallid sturgeon by topics relevant to the Effects Analysis (EA). 


\section{Aquaculture}

Few published studies were found that addressed artificial propagation or culture of pallid sturgeon. Much of the information learned through the culture of pallid sturgeon that may be of value for informing EA models may exist as records housed at the hatcheries and research facilities involved with propagation. These facilities may possess data regarding egg fertilization or hatch rates, survival from egg to free embryo, or the influence of water quality on developing eggs or young sturgeon. Original research that may provide useful insight on the importance of culture-related stressors (that is, acute ammonia exposure, low dissolved oxygen, and crowding) on juvenile pallid sturgeon was conducted by Nelson and Small (2014); their results indicate a low stress response to ammonia, a substantial response to low dissolved oxygen, and persistent response to crowding. These results are broadly similar to an earlier study (Barton and others, 2000) that concluded that pallid sturgeon juveniles do not respond strongly to handling stress during aquaculture operations.

\section{Bioenergetics}

One published bioenergetics model was found for pallid sturgeon (Wildhaber and others, 2015a); this model applies climate change scenarios and parameterizations of water temperature and flow based on previous modeling by Chipps and others (2008). Ongoing laboratory work at South Dakota State University also is addressing the energetic requirements and expenditures of various stages of pallid sturgeon. Although not peer reviewed, a final report (Chipps and others, 2008) to the South Dakota Department of Game, Fish and Parks describes a bioenergetics model for juvenile (less than $(<)$ $300 \mathrm{~mm}$ fork length [FL]) pallid sturgeon. The model is applicable for water temperatures between 13 degrees Celsius $\left({ }^{\circ} \mathrm{C}\right)$ and $28{ }^{\circ} \mathrm{C}$. Information useful to populate bioenergetics models, such as swimming speeds, water temperatures, and water velocities encountered during feeding and migration may be available from modeling and measurement datasets held by U.S. Geological Survey (USGS), USACE, and other sources. Data on pallid sturgeon energetic needs and expenditures at water temperatures less than $13{ }^{\circ} \mathrm{C}$ are needed to adequately model winter conditions because pallid sturgeon encounter temperatures less than $13{ }^{\circ} \mathrm{C}$ for at least 4-6 months of each year.

\section{Diet}

Twelve research studies were found that have quantified the dietary habits of pallid sturgeon. Most studies focused on juvenile to adult stages; however, several examined early-life history (that is, age-0) food habits and feeding requirements of Scaphirhynchus sturgeon The genus Scaphirhynchus includes the pallid sturgeon and closely related Scaphirhynchus platorynchus (shovelnose sturgeon). The most valuable of these studies to inform or evaluate models developed through the EA may be those where diets of three size classes of age-0 Mississippi River Scaphirhynchus sturgeon were quantified and compared across seasons and habitat types. Diets from a variety of habitat types were assessed for energy return and energy condition (Sechler, 2010; Sechler and others, 2012, 2013). Braaten and others (2012) examined food habits and growth of 51 age- 0 pallid sturgeon that were originally released into the Missouri River below Fort Peck Dam as free embryos. Research by Braaten and others (2012) provides the only empirical age-0 food habits for pallid sturgeon from the Missouri River. Kappenman and others (2011), through laboratory research, provide data for mortality correlated to starvation of age-0 pallid sturgeon that may be useful for defining the starvation "point-of-no-return" for a variety of bioenergetic, habitat, or dispersal models.

Juvenile (greater than (>) age-1) dietary studies have focused on comparison of pallid and shovelnose sturgeon diets (Wanner, 2006; Hoover and others, 2007; Wanner and others, 2007) or when 
pallid sturgeon undergo an ontogenetic shift in diet from invertebrates to fish (Gerrity, 2005; Gerrity and others, 2006; Grohs, 2008; Grohs and others, 2009; French and others, 2013a). Grohs (2008) and Grohs and others (2009) evaluated the spatial and temporal patterns in macroinvertebrate abundance and described their habitats. Selectivity of macroinvertebrates in juvenile pallid sturgeon diets was enumerated from this research for the reaches of the Missouri River above and below Gavins Point Dam. These data may be useful for evaluating models of habitat suitability for age-0 pallid sturgeon.

\section{Early-Life Dispersal}

Six research studies have been completed that evaluate drift dynamics of free-embryo pallid sturgeon and dispersal behavior of stocked juvenile pallid sturgeon. Post-stocking dispersal and condition of age-1 pallid sturgeon under different acclimation treatments and site-specific conditions were assessed in the Upper Missouri River (Oldenburg, 2008; Oldenburg and others, 2011). This research may be useful in models related to stocking- and population-augmentation management hypotheses. All models developed to evaluate the drift of free-embryo pallid sturgeon (Kynard and others, 2007; Braaten and others, 2008; Braaten and others, 2010; Braaten and others, 2012; Erwin and Jacobson, 2014) include features that may prove useful in evaluating or parameterizing new models of drift or dispersal (drift time, lateral drift distribution, drift distance, behavior, and influence of temperature and current velocity). The models of Kynard and others (2007) were derived through a laboratory study and were the only research that assessed the influence of retention habitat (that is, eddies) on drift distance and behavior. Braaten and others (2010) included an assessment of lateral drift across the river channel by sampling a variety of macrohabitat types. The most recent empirical study of drift by Braaten and others (2012) may provide the most relevant information because it was developed for the Upper Missouri River downstream of Fort Peck Dam and there are several drift and dispersal management hypotheses for this river reach. The drift models developed by Braaten and others (2012) provide a cumulative drift-distance distribution for a range of water temperatures and velocities. Hydraulic modeling of free embryo drift as an advection/dispersion process (Erwin and Jacobson, 2014) has been used to assess sensitivity of drift distance to physical conditions in the Lower Missouri River. This methodology demonstrates a useful approach to evaluating how drift of free embryos varies with flow and temperature management.

\section{Fecundity}

Four peer-reviewed publications containing original data describing fecundity of pallid sturgeon were found; each publication builds on previous work. Albers and others (2013) report a mean relative fecundity estimated by using ultrasound was 10.7 plus or minus ( \pm ) 4.9 eggs per one gram of total fish weight, but fecundity increased with fish length. The authors also suggest that a positive relation exists between fecundity, fork length, and distance from the Missouri River mouth, but additional fecundity data are needed because trends can be confounded by other factors including temperature, habitat, prey abundance, flow regime, and river size. The use of ultrasound as a tool to estimate fecundity was described by Bryan and others (2007). The publication addresses correction factors needed to improve accuracy of non-invasive estimates of fecundity. Preceding papers used traditional techniques to determine fecundity of pallid sturgeon. One paper (Keenlyne and others, 1992) determined fecundity of a single fish from the Upper Missouri River Basin and another paper (George and others, 2012) determined fecundity of two individuals from the Lower Mississippi Basin. 


\section{Genetics}

None of the current (2015) 14 published pallid sturgeon papers on genomics provide data directly relevant to EA modeling of flow and form management actions; these papers may be relevant to propagation actions. Currently (2015) available papers investigate and develop genomic techniques to distinguish Scaphirhynchus species and their intermediates (hybrids), aiding in hatchery propagation. These papers establish the importance that genomics has in propagating fit and genetically diverse populations to supplement limited wild populations. Current (2015) research further suggests the importance of centralizing and increasing accessibility to existing basin-wide genomic databases and funding tissue archives to increase the effectiveness of supplemental stocking. Seminal work by Jager (2005) on the genetic and demographic implications of stocking Acipenser transmontanus (white sturgeon) described a modeling approach that used individual white sturgeon to determine the effect of genomics on hatchery propagation with implications to subsequent stocking and population dynamics. Similar modeling might be useful to explore implications of population augmentation efforts in pallid sturgeon genetic structure in the Missouri and Mississippi River systems. Such modeling has not been conducted to date.

\section{Growth}

Growth of Scaphirhynchus species has been well studied in the Mississippi and Missouri Rivers. Several studies report standard growth models relating age to weight or length (that is, von Bertalanffy growth functions) (Morrow and others, 1998; Gerrity, 2005; Killgore and others, 2007; Shuman and others, 2011). Growth was reported monthly (MacConnell and others, 2007) for an experimental holding of pallid sturgeon or daily for free embryos and larvae released in the Upper Missouri River (Braaten and others, 2012). It should be noted that growth rates were not functionally related to abiotic or biotic factors in these studies, which limits usefulness in current EA modeling efforts.

\section{Habitat}

A dozen publications were found that provide original data and interpretations regarding habitats used by juvenile and adult life stages of pallid sturgeon However, these reports provide limited information for the current EA modeling because information is lacking on how habitat quality and quantity may affect growth, survival, and population dynamics of pallid sturgeon. The publications are discussed in the following sections by life stage.

Adults

Telemetry studies of adult pallid sturgeon habitat occupancy of mesohabitats indicate that adults select channel borders, downstream island tips, submerged sandbars between wing dikes, and banks (Hurley, 1999; Koch and others, 2012; Herrala and others, 2014). Seemingly contradictory results among studies are possibly related to the subjective nature of mesohabitat classifications; such classifications are useful for organizing the understanding of mesohabitats but may obscure important relations among continuously varying, three-dimensional abiotic variables. Microhabitat data (point measurements of depth, velocity, and substrate) consistently show that adult pallid sturgeon occupy moderate column-averaged velocities (0-1.5 meters/second [m/s]) (Bramblett and White, 2001; Snook and others, 2002; Swigle, 2003), although interpretation of velocity data is often confounded by differences in methods used to obtain water velocity, particularly, whether fish focal velocity (typically inferred to be "bottom" velocity for pallid sturgeon), midcolumn, or average column velocity are recorded. The nature of sand bedforms and their effects on boundary-layer turbulence and flow 
separation, likely create specific velocity distributions and turbulence at the scale of fish occupancy. These details are not measured by conventional velocity meters (Gaeuman and Jacobson, 2007; Jamieson and others, 2009; Jamieson and others, 2011; McElroy and others, 2012). Depths occupied by pallid sturgeon are highly variable as a result of availability of depth and by interaction with turbidity. Mean depth occupied by pallid sturgeon on the relatively shallow Lower Platte River was $0.9 \mathrm{~m}$ (Swigle, 2003) but ranged 0.6-14.5 m on the Lower Yellowstone River (Bramblett and White, 2001). Adult shovelnose sturgeon depth selection on the Lower Missouri River varied by river segment, with avoidance of depths less than $2 \mathrm{~m}$ in less-turbid water, indicating the interacting role of depth and turbidity in providing habitat (Reuter and others, 2009). As a benthic fish, pallid sturgeon have a strong preference to channel substrate and bedforms. On the Yellowstone River (fig. 1), pallid sturgeon selected sand substrates and sand dune mesohabitats while avoiding gravel-cobble substrate, whereas shovelnose sturgeon selected gravel-cobble (Bramblett and White, 2001); this result indicates that these sympatric species may be spatially separated where a range of substrates is present.

Relevance of adult habitat selection to demographic processes can be inferred more clearly if a fish's life stage is known. Adult pallid sturgeon habitat-selection studies under the CSRP have focused on migration and spawning habitats for males and females known to be reproductive. On the channelized Lower Missouri River, upstream migrating reproductive pallid sturgeon use relatively low velocity $(0.25-1.0 \mathrm{~m} / \mathrm{s})$ and moderate depths $(0.5-4.0 \mathrm{~m})$ on inside bends, then efficiently ferry across the channel at high-velocity crossovers to continue up the next inside bend (McElroy and others, 2012). In this fashion, the migrating fish avoid high velocities and depths associated with the constructed navigation channel (DeLonay and others, 2015), which is thought to minimize the expenditure of energy. In contrast, in the unchannelized Yellowstone River, upstream migrating pallid sturgeon use depths and velocities in proportion to their availability, indicating that in an unchannelized river, there is no energetic advantage to be gained by avoiding deeper depths and higher velocities. These data support the hypothesis that existing channel hydraulics in modified and unmodified segments are not a substantive impediment to upstream migration and associated energy expenditure for the pallid sturgeon. When spawning, Yellowstone River pallid sturgeon have been documented to use patches of gravel among migrating sand dunes. In the Lower Missouri River (fig. 1), spawning has been documented at multiple locations in zones of velocity convergence, dominantly in outside bends against coarse revetment (DeLonay and others, 2009; DeLonay and others, 2015). The differences between spawning-patch hydraulics on the least-altered Yellowstone River and those on the Lower Missouri River may indicate functional characteristics that are lacking on the Lower Missouri River for survival of gametes and embryos.

Early-life stages.-Studies have begun to define where age-0 (free embryos, exogenously feeding larvae, and juvenile stages) of Scaphirhynchus species are found. Occupancy has implications for understanding which habitats are supportive of growth and survival, but by itself occupancy is not sufficient to determine population demographic parameters. Field, laboratory, and hydraulic studies indicate that during the 11-17 days required between hatch and first feeding, free embryos have the potential to drift downstream from incubation sites hundreds of miles; information on hydraulics and development rate have been used to calculate likely dispersal distances (Kynard and others, 2002; Braaten and others, 2008; DeLonay and others, 2009; Braaten and others, 2012; Erwin and Jacobson, 2014; DeLonay and others, 2015). However, it is possible that pallid sturgeon free embryos delay drift by developing within interstices of spawning substrate for some unknown number of days, which could result in substantially decreased dispersal distance - a possibility inferred from recent work on other sturgeon species (McAdam, 2011, 2012; Boucher and others, 2014; Crossman and Hildebrand, 2014; DeLonay and others, 2015). In the Upper Missouri and Yellowstone Rivers, drift information indicated 
that reservoir drawdowns may be effective in increasing survival rates (Gerrity and others, 2008), whereas in the lower river, drift information may be useful to determine locations where free embryos are likely to "settle" from the drift under varying channel reconfigurations.

Occupancy data developed from the HAMP and PSPAP provide some understanding of habitats in which age-0 Scaphirhynchus sturgeon settle and survive on the Lower Missouri River (Ridenour and others, 2011b; Gemeinhardt and others, 2015; Gosch and others, 2015). Generally these data indicate typical ranges of depth and velocity occupied by age-0 Scaphirhynchus sturgeon but they do not support hypothesized relations to shallow-water habitats measured as 0-1.5 meter depths. Ongoing studies of stomach contents may provide insights into whether these habitats provide sufficient food resources to support growth (Todd Gemeinhardt, USACE, written commun., 2014). Similar studies on age-0 Scaphirhynchus sturgeon in the Middle Mississippi River indicate that where caught, age-0 sturgeon rarely had empty stomachs. Their diets were dominated by Ephemeroptera and Chironomidae (Sechler and others, 2012), indicating that a habitat-based food-production index may be informative to link habitat to growth of early-life stages of pallid sturgeon.

\section{Movements}

Ten pallid sturgeon publications describing movements of pallid sturgeon were found, which may aid the pallid sturgeon EA. Various movement summaries were provided for embryo, larvae, juvenile, and adult sturgeon. Drift distance (measured and modeled) and drift velocity were reported for larval fish from both laboratory and field experiments (Kynard and others, 2007; Braaten and others, 2012). For juvenile and adult life stages, movement descriptions were typically assessed using acoustic or radio-telemetry techniques. Six papers had data summaries that reported range of movement (in kilometers), total movement (in kilometers), or movement rate (in kilometers per hour, kilometers per day) by year, season, or diel period. Description of movement patterns during spawning periods in four papers allowed for determination of spawning areas and spawning time periods (Bramblett and White, 2001; DeLonay and others, 2007; DeLonay and others, 2009; DeLonay and others, 2015). General habitat descriptions where pallid sturgeon were found were often described during movement studies using metrics such as substrate, channel description, temperature, depth, turbidity, or water velocity.

\section{Population Assessment}

Eight reports, which provide estimates of population size and (or) dynamic rates, were found to be potentially relevant and useful for the pallid sturgeon EA. Several conference abstracts referenced mark-recapture data that may also potentially be useful but would require re-analysis to suit the requirements of the EA (Kennedy and others, 2005; Killgore and others, 2005; Reed and Dean, 2005). Several studies report population abundances or densities that may be used to initialize population models (Gardner, 2005; DeHaan and others, 2008; Braaten and others, 2009; Wildhaber and others, 2011b; Steffensen and others, 2012). Studies reporting estimates of annual survival were fewer; these studies provided estimates for adults based off of catch curves (Colombo and others, 2007; Phelps and others, 2010), mark-recapture estimates (Steffensen and others, 2012; Winders and Steffensen, 2014; Wildhaber and others, 2015b), or population reconstructions (Braaten and others, 2009).

Recycling of dynamic rates from other studies or species is a common occurrence. Bajer and Wildhaber (2007) used juvenile survival of Acipenser oxyrinchus desotoi (gulf sturgeon) in a population viability model of shovelnose sturgeon and annual mortality for fish greater than ( $>$ ) age-2 from estimates for Lower Missouri River shovelnose sturgeon. Similarly, Colombo and others (2007) used these same estimates to parameterize a yield per recruit model for shovelnose sturgeon. Studies of Scaphirhynchus population dynamics rarely linked dynamics rates to abiotic or biotic factors, except for 
studies conducted by Phelps and others (2010), where water temperature and river stage were associated with age-0 survival.

\section{Predation}

Predation on early-life stages of fishes can influence recruitment to subsequent life stages. Predation on pallid sturgeon eggs, free embryos, larvae, and juveniles in rivers is suspected, but has not been reported in peer-reviewed literature. Adult pallid sturgeon may be vulnerable to predation by birds and mammals, such as otters, but no records of predation on adult pallid sturgeon were found. Laboratory studies have shown that Micropterus dolomieu (smallmouth bass), Sander vitreus (walleye), Pylodictis olivaris (flathead catfish), and Ictalurus punctatus (channel catfish) will consume age-0 pallid sturgeon (French, 2010; French and others, 2010; French and others, 2013b), but relative vulnerability of age- 0 pallid sturgeon $>40 \mathrm{~mm}$ FL is believed to be low (French and others, 2013b). All predators tested in the laboratory showed negative to neutral selection for juvenile pallid sturgeon when alternative prey were present. Consumption of juvenile pallid sturgeon in the laboratory was lowered by the presence of alternative prey, but predation was not eliminated.

Predation on age-0 pallid sturgeon in the laboratory was not influenced by turbidity. It is important to note that the laboratory studies to date (2015) did not assess vulnerability of embryos or newly hatched free embryos. All trials have used age- 0 pallid sturgeon that had fully developed scutes, which may be effective at deterring predation once fish achieve this life stage. It is unlikely that other data or datasets exist from which rates of predation or vulnerability of pallid sturgeon to predation can be assessed.

\section{Recruitment}

A single study was identified that addressed factors influencing pallid sturgeon recruitment to age-0. The report by DeLonay and others (2009) provides an in-depth review of pallid sturgeon reproduction and recruitment. The report documents the hypothetical role of flow regime on pallid sturgeon recruitment as well as a suite of other factors; however, no empirical data relating the recruitment of early-life history stages to the population was presented.

\section{Spawning}

Several publications from the CSRP have documented spawning and spawning-related movements. Spawning (release of eggs) of pallid sturgeon in the wild was first documented in 2007 based on tracking reproductive females to apices of their spawning migrations and documenting complete loss of eggs in recaptured fish (DeLonay and others, 2009). Similar methods continue to be used to track and document spawning and failure to spawn (DeLonay and others, 2015). Synthesis of coordinated data collected on blood hormones has provided a useful model for physiological reproductive cycles related to spawning in pallid and shovelnose sturgeon (DeLonay and others, 2007; Papoulias and others, 2007; DeLonay and others, 2009; Papoulias and others, 2011). Spawning migrations and habitats have been quantified in detail in the Lower Missouri River, providing understanding of habitats selected by reproductive pallid sturgeon in a highly altered river system (DeLonay and others, 2009; DeLonay and others, 2010; DeLonay and others, 2012; McElroy and others, 2012; DeLonay and others, 2015). Coordinated studies in the Yellowstone River have begun to quantify spawning habitats in what is presumed to be an undisturbed physical environment (DeLonay and others, 2015) that potentially allows scientists to evaluate how spawning-habitat quality relates to 
survival of gametes and embryos. Herzog and others (2005) suggested confirmation of Scaphirhynchus spawning in the Mississippi River through egg collection during active sampling.

An analysis of shovelnose sturgeon spawning patterns in the Lower Missouri River indicated statistically identifiable clusters of spawning migrations, and further identified some patterns that were more likely to be indicative of successful spawning compared to other patterns (Wildhaber and others, 2011c). This study did not specifically identify the cause for the different patterns, but indicated that patterns closer to Gavins Point Dam were less likely to be associated with successful spawning, possibly because of hydrologic influences.

The hypothesis that discharge pulses in the spring (spring rise) are necessary or sufficient to cue pallid sturgeon spawning behavior has been central to science efforts on the Missouri River because of the emphasis on naturalizing the flow regime in the 2000 and 2003 "Missouri River Biological Opinion" (U.S. Fish and Wildlife Service, 2000a, 2003) reports. Analyses by CSRP have identified temperature thresholds for spawning, but data are ambiguous on behavioral responses to discharge pulses (DeLonay and others, 2009; DeLonay and others, 2015). Reproductive migrations of pallid sturgeon on the Lower Missouri River show little evidence of correlation with natural and manipulated discharge pulses. On the other hand, reproductive migrations of pallid sturgeon on the Upper Missouri River indicate that fish may select between Upper Missouri and Yellowstone River migrations based on which river has the higher discharge or associated hydrologic cues (discharge characteristics, temperature, turbidity, or a combination of the three cues). A review of the effectiveness of purposeful spring rise releases from Gavins Point Dam concluded that no evidence is available that pulses had an effect on spawning behaviors (Doyle and others, 2011). An analysis of the pulses relative to natural spring pulses indicated that the peak magnitude of socially acceptable pulses was less than 20 percent of natural pulses (Jacobson and Galat, 2008). In aggregate, these reports indicate that data are available to define pulses that are not sufficient to cue pallid sturgeon spawning behavior and pulses that may be, but available information is not adequate to define pulses that are necessary for spawning cues, nor what functional relations might look like between pulse discharge characteristics and strength of the spawning behavior response.

\section{Recent Syntheses}

Several recent documents have synthesized information related to pallid sturgeon population decline. Links to uniform resource locators (URLs) for these documents are presented in the following along with summaries of their content.

\section{Revised Recovery Plan}

Early in 2014, the U.S. Fish and Wildlife Service released an updated recovery plan for the pallid sturgeon (U.S. Fish and Wildlife Service, 2014). The URL for this document is:

http://ecos.fws.gov/docs/recovery_plan/Pallid\%20Sturgeon\%20Recovery\%20Plan\%20First\%20Revisio n\%20signed\%20version\%20012914_3.pdf. The recovery plan synthesizes species history, present status of the population, threats leading to listing, recovery actions, and recovery strategy. A new factor identified in this revision of the recovery plan is the potential to recognize distinct population segments (DPS) for the pallid sturgeon based on criteria relating to separation and significance of population segments to the species. 
Threats identified in the recovery plan are listed below:

- Channelization, bank stabilization, impoundment, and altered flow regimes - Factors that simplify channel morphology, fragment river continuity, decrease connectivity with flood plains, and decrease life-stage cues;

- Water quality-Altered temperature, dissolved oxygen, and turbidity regimes are a concern as well as increased contaminants such as agricultural chemicals, metals, hydrocarbons, and polychlorinated biphenyls. Endocrine disrupting chemicals that may result in intersex are a special concern because of agricultural and urban wastewater effects.

- Entrainment-Potential for loss of pallid sturgeon due to entrainment in intake structures, towboat propellers, dredge operations, irrigation diversions, and flood-control diversions.

- Climate change-Potential for climate change to exacerbate existing sources of stress, especially through changes in reservoir management.

- Over-utilization for commercial, recreational, scientific, or educational purposes.

- Disease or predation.

- Inadequacy of existing regulatory mechanisms to regulate water quality, water quantity, and harvest or bycatch.

- Effects of new energy development.

- Hybridization with shovelnose sturgeon.

- Invasive species-Competition for food or space.

The recovery plan lays out specific criteria for recovery based on assumed effective population size and criteria in the Endangered Species Act of 1973 (16 U.S.C. ch. 35 § 1531): achievement of a self-sustaining diverse population of 5,000 adults within each of four management units. These criteria provide metrics that can be used as targets for modeling under the EA. The recovery plan also provides a long list of possible conservation and restoration actions, but without criteria for prioritization. Many of the actions involve improvement of the science information base for making recovery decisions.

Ecological Requirements for Pallid Sturgeon Reproduction and Recruitment in the Missouri River: A Synthesis of Science, 2005-12

This report (DeLonay and others, 2015) was produced by the U.S. Geological Survey Comprehensive Sturgeon Research Project as a synthesis of 8 years of research on reproductive ecology of the pallid sturgeon. The report frames research results in terms of relations to potential management actions and integrates the research results with PSPAP, HAMP, and other research studies results.

The CSRP synthesis report addresses the key, pallid sturgeon-related reasonable and prudent alternative (RPA) elements in the 2003 "Missouri River Biological Opinion" (U.S. Fish and Wildlife Service, 2003). The 2003 "Missouri River Biological Opinion" was based on the dominant hypotheses for population decline that existed at that time. Emphasis was on the role of the flow regime, specifically spring flow pulses (spring rises) to condition spawning substrate and cue reproductive aggregations and migrations, and the interaction of low flows with channel form to provide additional slow, shallow-water area to serve as rearing habitat for age-0 to juvenile pallid sturgeon. The 2003 "Missouri River Biological Opinion" also supported the role of flow pulses to provide connections with low-lying lands to stimulate primary and secondary productivity. CSRP studies on spawning habitat dynamics have shown that habitat patches selected for spawning by fish in the Lower Missouri River are 
dominantly on outside, revetted bends in the deepest, fastest, and most turbulent water. Studies in more natural habitat on the Yellowstone River have documented spawning in the middle of the channel over discrete patches of gravel within a sand-dominated channel; this channel arrangement may be more effective in attracting aggregations of reproductive fish compared to the nearly continuous revetment on the Lower Missouri River. Tracking of reproductive pallid sturgeon 2005-12 on the Lower Missouri River has produced no clear relations between spring rises or other suspected cues and spawning behaviors. The exception is water temperatures that consistently exert a threshold effect for spawning $16-18{ }^{\circ} \mathrm{C}$. In addition, the role of water temperature is documented by pauses and reversals in upstream migrations. The temperature changes have been associated with cold-weather frontal systems. In contrast to Lower Missouri River conditions, pallid sturgeon tracking at the Upper MissouriYellowstone confluence documents that in most years, most telemetered pallid sturgeon migrate out of the Missouri and into the Yellowstone Rivers in June-July in association with the spring pulse from the Yellowstone River, or on the falling limb of the pulse. This pattern was disrupted in 2011 when a highflow pulse with warm temperatures and high turbidity was contributed by the Milk River (fig. 1), followed by record releases from Fort Peck Dam; that year, 36-39 percent of the telemetered population migrated up the Upper Missouri River. This result supports the hypothesis that sufficiently large flow pulses, or pulses with particular relations to temperature, timing, and turbidity, may trigger migration and aggregation. It is not clear that pulses sufficient to elicit spawning activities are within reservoirmanagement authorizations or could be coordinated with sufficient water temperature. Notably, a pallid sturgeon free embryo was captured on the Upper Missouri River in 2011 and another single, genetically confirmed embryo was captured on the Yellowstone River in 2012. Four pallid sturgeon free embryos were captured on the Yellowstone River in 2013 (P.J. Braaten, USGS, written commun., 2014).

Research on free-embryo drift has shown the potential for hundreds of km of downstream dispersal. Lack of distance to accommodate 11-17 days of drift on the Upper Missouri and Yellowstone Rivers is thought to be responsible for recruitment failure in the Upper Missouri and Yellowstone rivers (Braaten and others, 2012; Guy and others, 2015). Long drift distances in the Lower Missouri River may be responsible for shifting Lower Missouri River subpopulations farther into the Middle Mississippi River (fig. 1), but do not necessarily indicate loss to the population. Physical understanding of drift processes indicates the dominant role of mean velocity in downstream transport of free embryos; mean velocities could be slowed through decreased discharges or increased channel hydraulic radius (width and topographic diversity). In addition, the probability that free-embryos are transported into and retained in channel marginal habitats is theoretically amenable to channel re-engineering that would increase cross-channel secondary currents in bends or channel expansions.

Longitudinal differences in female pallid sturgeon fecundity lend support to the hypothesis that recruitment failure may be due, in part, to fish having insufficient nutrition to produce the numbers of gametes needed for the population to grow, perhaps because of simultaneous declines in prey-fish populations and their habitats. Establishing a chain of causality from habitat decline, to prey-fish populations, to sturgeon diets, to sturgeon fecundity, and to pallid sturgeon population growth presents a considerable scientific challenge.

In addition to the dominant hypotheses relating pallid sturgeon populations to changes in flow regime and channel morphology, other factors have been identified that might be sources of stress and contribute to recruitment failure. Among these are competition for food and space, and predation of eggs, free embryos, or larvae. Concerns about water quality and contaminants, in particular, have been persistent because of the known increases in exposure to chemical stressors. Ambient water-quality monitoring on the Lower Missouri River has demonstrated summer episodes when dissolved oxygen concentrations are below 5 milligrams per liter, which is a threshold that may be stressful especially to 
age-0 and juvenile sturgeon (Blevins, 2011). Documented cases of intersex in shovelnose and pallid sturgeon indicate that agricultural and municipal sources of endocrine disrupting chemicals may also have a role in pallid sturgeon recruitment failure (Koch and others, 2006).

\section{Pallid Sturgeon Basin-Wide Contaminants Assessment}

The Pallid Sturgeon Basin-wide Contaminants Assessment is a landscape-level identification of potentially harmful contaminants, their distribution within pallid sturgeon habitat, and their effects on pallid sturgeon. The overall goals of this multi-agency collaborative project have been to identify those contaminants of concern (COCs) that pose a potential exposure risk in each pallid sturgeon management unit and describe potential adverse effects in pallid sturgeon from exposure to toxic concentrations of these contaminants. In addition, the assessment includes identification of data gaps, management recommendations, and research hypotheses for the purpose of aiding in pallid sturgeon recovery. The report is intended to be accompanied by a geo-referenced geospatial database that will display userselected chemical contaminant information. This geographic information system (GIS) data layer accesses geo-referenced contaminant data from existing databases for use in identifying potential "toxic hotspots" where pallid sturgeon habitat and contaminants may be collocated. The assessment document and GIS map are scheduled for publication in 2016. Draft copies may be requested from Molly Webb, USFWS, Bozeman, Montana.

Extant analytical chemistry data from samples of river water, sediment, and sturgeon tissue (as whole body, fillet, or organs) resulting from past studies, assessments, or monitoring activities throughout the species' range were used to establish a list of contaminants. The list includes: trace elements, pesticides, organic industrial contaminants, hormones, nutrients and other potential waterquality contaminants. Generally, environmental samples collected from January 1, 2001, through December 31, 2008, were used except when there were insufficient data within this time frame. Two principle databases were searched to compile the water chemistry data: the U.S. Environmental Protection Agency's (EPA) STORET (U.S. Environmental Protection Agency, 2011) and the U.S. Geological Survey’s (USGS) National Water Information System (NWIS) (U.S. Geological Survey, 2011a). The NWIS database and the sediment chemistry database from the USGS's Upper Mississippi River Sediment Quality Database provided sediment chemistry data (U.S. Geological Survey, 2011b). Other sources of water and sediment chemistry data included tribal, government, and university data published in reports or the scientific literature. Three fish-tissue residue databases were queried: the National Contaminants Biomonitoring Program database (U.S. Geological Survey, 2011a) and the 1995 Biomonitoring of Environmental Status and Trends database (U.S. Geological Survey, 1995), and the USFWS Environmental Contaminants Data Management System (ECDMS) (U.S. Fish and Wildlife Service, 2011). However, only the USFWS database contained sturgeon tissue-chemistry data. Other sources of fish tissue-residue data included government and university data published in reports or the scientific literature. Original data for the contaminant assessment are provided in appendices to the assessment. The assessment will be useful in the EA because it puts potential contaminants in a framework that can be used to assess exposure to pallid sturgeon and to establish if effects concentrations have been reached. As indicated in the report, specific assessments of pallid sturgeon exposure and responses to contaminants have not been a research emphasis despite prominence in recovery plans (Dryer and Sandvol, 1993; Jordan, 2013), and, therefore, substantial information gaps exist. To begin addressing this data gap, the EA team has summarized the limited research that is currently (2015) available that investigates the effects of contaminants on Scaphirhynchus spp. in the Missouri River Basin with emphasis on future research needs (appendix A of this report). 


\section{Relevant Scientific Literature Database}

Scientific information relevant to understanding pallid sturgeon population dynamics has increased rapidly since 2003 (fig. 2). In addition to information that relates specifically to the pallid sturgeon, there have been comparable increases in information related to Missouri River physical and chemical processes, riverine ecology, flood plain ecology, and other native and nonnative species. For the purposes of the EA process, the EA team has created an Endnote ${ }^{\mathrm{TM}}$ (Thomson Reuters New York, New York) database with links to literature cited in our reports. This database is meant to be an archival record of information sources and will be sharable among agencies and scientists working on pallid sturgeon recovery, subject to applicable copyright laws.

The Endnote ${ }^{\mathrm{TM}}$ database and library assembled for the pallid sturgeon EA is limited to sources cited in our documents; however, the EA also takes advantage of a larger database and library maintained by USGS-CERC, which contains more than 12,000 records related to river processes, native, and endangered species. Presently (2015), the pallid sturgeon EA Endnote ${ }^{\circledR}$ database contains more than 300 records of references that we have used in our documents.

\section{Review of Relevant Models}

The purpose of the EA effort is to conceptualize and quantify the effects of system operations and habitat restoration actions on the pallid sturgeon. The EA will use existing data and models where applicable, develop new models as needed, and will be based upon the best scientific information available within the background of hydrologic and fluvial processes on the Missouri River. The EA is expected to provide insight and understanding of how management actions are likely to affect the listed species over the next 30-50 years within each of two geographic regions, the Upper and Lower Missouri River.

A population model that can be linked to the outputs (that is, survival) of the CEMs is required to make predictions for hypotheses emerging from the recalibration and refinement process. Population models can be structured by age or stage. In an age-structured model, population dynamics occur on an annual time step and individuals transition to the next age given an annual survival rate. Stagestructured models organize a population into biologically relevant stages that may be organized by size, age, or combination of size and age. Stages can represent various life histories in the population of interest and occur over varying time periods. For example a stage can last few days or several years. A commonly used stage structure organizes a population into juvenile and adults stages. In this case, an organism can reside in the juvenile stage for a few days or several years. A stage-based approach to modeling populations is intended to capture additional biological realism and is congruent with the conceptual life cycle model for pallid sturgeon described by Wildhaber and others (2011a), which provides the template for the CEMs developed (Jacobson and others, 2015). While abundance at each stage is modeled using this population model, additional models will be needed to predict the influence of habitat, water quality, and aquatic productivity on growth of individuals within those stages to elucidate effects of ecological factors and management on stage survival. Stage survival rates must be relatively high to produce a strong year-class (Walters and Collie, 1988; Parsley and others, 2002). Increased stage mortality, either occurring at a single life stage or cumulative over several stages, will cause a reduction in population abundance and can lead to recruitment failure (Parsley and others, 2002).

The process of transitioning from one stage to another in a stage-structured population model is related to growth. For example, the transition from juvenile to the adult stage for pallid sturgeon reflects increases in length resulting from growth. The growth process for fish is governed by abiotic (for 
example, temperature) and biotic factors (for example, prey availability), which can be formally developed in bioenergetics models. Additionally, transitions from one stage to another can be influenced by habitat. For example, habitats with high energetic demands may reduce growth rates as energy is diverted from growth and allocated to maintenance. Accounting for growth with a bioenergetics model that estimates the potential effects of habitat will be a critical component to model adequately the sizedependent transitions between stages in a stage structured pallid sturgeon population model.

This review sought to identify existing pallid sturgeon models and models under development that could reasonably be applied to the EA and to identify gaps in data needs or model parameters that may require model adaptation or further development to fill areas where existing models cannot reasonably be used. The goal is to determine if previously developed models will be capable of integration, and if they can be applied at the temporal and spatial scales of interest.

The following section ("Population Models") summarizes existing population, bioenergetics, and habitat-use models identified for pallid sturgeon. Models for other sturgeons were also identified; as such these models may provide necessary parameters in future modeling efforts; however, efforts to evaluate and summarize these models were limited. It should be recognized that evaluation of models and identification of existing parameters will continue to be an ongoing process as model needs are identified during the EA.

\section{Population Models}

Pallid sturgeon.-Four population models pertaining to pallid sturgeon were identified by querying existing literature and sturgeon experts (table 1). Only the models by Steffensen and others (2013a) and Wildhaber and others (2015b) have been peer-reviewed and published. All identified models imposed an age structure to model pallid sturgeon population dynamics. With the exception of the modeling efforts of Reynolds and Tyre (2011b), all identified models were population viability models that predicted the pseudo-extinction probability of the simulated population. The advantages of these models are that they are easily understood; however, outputs such as extinction probability cannot be monitored, and therefore, cannot be used to inform the effectiveness of management. The model developed by Reynolds and Tyre (2011b) predicted the effect of changes in processes or conditions on survival in terms of parameter elasticity (sensitivity of the parameter to change accounting for parameter magnitude). The model indicates that fecundity (numbers of adult females spawning in a given year), annual survival of adults, which is highly correlated with fecundity, and growth of age-0 fish are key drivers of population growth. Additional summaries and comments for the five models identified are listed in table 1. It should be noted that although these models were developed for pallid sturgeon, some parameters were obtained from related sturgeons. For example, Reynolds and Tyre (2011) used a parameter for fecundity that was developed for white sturgeon and a parameter for age- 0 survival from an Acipenser oxyrinchus oxyrinchus (Atlantic sturgeon) population model. While it is common to borrow parameters from models for related species for population modeling, the paucity of information available to parameterize models for any sturgeon species limits the ability to assess validity of borrowing parameters.

Related sturgeons. - Three published population models for shovelnose sturgeon were identified (table 1). All models focus primarily on evaluating the effects of harvest on populations or population viability. Published models included the population viability model of Bajer and Wildhaber (2007) and equilibrium yield models to understand the effect of shovelnose sturgeon harvest by Koch and others (2009) in the Mississippi River and Quist and others (2002) for the Missouri River. 
Table 1. Scaphirhynchus albus (pallid sturgeon) and Scaphirhynchus platorynchus (shovelnose sturgeon) population models identified

[No bioenergetics or habitat models were identified for pallid or shovelnose sturgeon. FAST refers to the Fishing Activity Simulation Tool. FAMS refers to the Fishery Analysis and Modeling Simulator]

\begin{tabular}{|c|c|c|c|c|}
\hline Structure & Status of model & $\begin{array}{l}\text { Language/ } \\
\text { software }\end{array}$ & Output & Source/contact \\
\hline \multicolumn{5}{|c|}{$\begin{array}{c}\text { Pallid Sturgeon } \\
\end{array}$} \\
\hline Age & $\begin{array}{l}\text { Published, peer- } \\
\text { reviewed }\end{array}$ & Microsoft Excel....... & Population viability..... & (Wildhaber and others, 2015b). \\
\hline Age & $\begin{array}{l}\text { Non-peer reviewed } \\
\text { report }\end{array}$ & 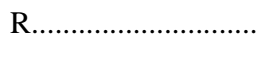 & $\begin{array}{l}\text { Elasticity values for } \\
\text { annual transitions }\end{array}$ & (Reynolds and Tyre, 2011a). \\
\hline Age & $\begin{array}{l}\text { Published, peer- } \\
\text { reviewed }\end{array}$ & Microsoft Excel....... & Population viability..... & (Steffensen and others, 2013b). \\
\hline Age & $\begin{array}{l}\text { Unpublished, draft } \\
\text { not for release }\end{array}$ & $\mathrm{C}$ & Population viability..... & $\begin{array}{l}\text { H. Jager, Environmental Sciences } \\
\text { Division, Oak Ridge National } \\
\text { Laboratory. }\end{array}$ \\
\hline \multicolumn{5}{|c|}{ Shovelnose Sturgeon } \\
\hline Age & $\begin{array}{l}\text { Published, peer- } \\
\text { reviewed }\end{array}$ & Microsoft Excel....... & Population viability..... & (Bajer and Wildhaber, 2007). \\
\hline Age & $\begin{array}{l}\text { Published, peer- } \\
\text { reviewed }\end{array}$ & FAST/FAMS........... & Equilibrium yield......... & (Koch and others, 2009). \\
\hline Age & $\begin{array}{l}\text { Published, peer- } \\
\text { reviewed }\end{array}$ & FAST ........................... & Equilibrium yield......... & (Quist and others, 2002). \\
\hline
\end{tabular}

\section{Bioenergetics}

One published bioenergetics model was found for pallid sturgeon (Wildhaber and others, 2015a). This model relates fish growth to climate change scenarios using relatively simple parameterizations of water temperature and velocity. The model indicates that pallid sturgeon dietary switch from invertebrates to prey fish is necessary to explain observed growth rates. An additional potential source was found in a peer-reviewed publication by Bevelhimer (2002) that developed a bioenergetics model for white sturgeon. Promising research is currently (2015) underway to parameterize pallid sturgeon bioenergetics models by researchers at South Dakota State University, which will likely provide useful information and parameters for modeling pallid sturgeon growth.

\section{Habitat}

Habitat models include those that establish statistical measures of habitat selection and those that use selection criteria in hydrodynamic modeling to simulate habitat availability. There has been increasing research into pallid sturgeon habitat selection (occupancy compared to availability) that may potentially provide suitable probabilistic relationships required for quantification of the effects of flow regime and channel reconfiguration on habitat availability. For example, studies of pallid sturgeon habitat selection by Herrala and others (2014) provided estimates of usage for varying habitat types by radio-telemetered pallid sturgeons in the Lower Mississippi River. Similarly, habitats used by pallid sturgeon in the Missouri River have been assessed by Koch and others (2012), Gerrity and others (2008), Jordan and others (2006), and Gerrity (2005). Additional work has been done for combinations of pallid and shovelnose sturgeon in the Missouri and Mississippi Rivers (Constant and others, 1997; Reuter and others, 2009). Coordinated telemetry and habitat mapping studies have been successful in quantifying habitat selection for reproductive pallid sturgeon on the Lower Missouri and Yellowstone Rivers (DeLonay and others, 2009; DeLonay and others, 2010; DeLonay and others, 2012; McElroy and others, 2012; DeLonay and others, 2014; DeLonay and others, 2015). Habitat selection studies for larval and juvenile pallid sturgeon result in less-definitive, but useful, measures of habitat selection (Ridenour and others, 2011b; DeLonay and others, 2015; Gemeinhardt and others, 2015; Gosch and others, 2015). 
Several hydrodynamic models have been developed in parallel with the habitat selection efforts. These models vary with respect to model codes, resolution, degree of calibration and (or) validation, spatial location and scale, and, most importantly, habitat criteria (Bowen and others, 2003; Jacobson and Galat, 2006; Johnson and others, 2006; Jacobson and others, 2009; Papanicolaou and others, 2011). Many of the models have included the definition of pallid sturgeon shallow-water rearing habitat (0-5 feet deep, 0-2 feet per second) in their assessments, but output of these models can typically be reclassified in a wide range of combinations of hydraulic variables, spatial variation, and biological criteria. The hydrodynamic modeling of four reaches of the Lower Missouri River by Jacobson and others (2009) explored a wide range of potential habitat criteria including measures of flow deformation and patch dynamics. This approach demonstrates the potential utility of using hydrodynamic models to simulate pallid sturgeon habitat, contingent on existence of robust, biologically relevant definitions of habitat. Hydraulically simple advection/dispersion models of particle transport also have been used to simulate effects of discharge, channel morphology, and temperature on transport and fate of passively drifting free embryos (Erwin and Jacobson, 2014).

Thus, the existing literature is beginning to provide quantitative, statistical criteria for habitat selection, typically in relation to availability. In addition, a number of hydrodynamic models exist and are amenable for use in simulating habitat availability resulting from combinations of flow and channel reconfiguration. However, the explicit linkages from habitat quantity or quality to growth and survival are not presently available and may have to be inferred until research can establish those links.

\section{Population Model Parameters}

Pallid sturgeon specific-demographic rates and characteristics are currently being compiled with the objective of parameterizing quantitative models of the CEMs from sources such as Steffensen and others (2013c). There will undoubtedly be demographic rates required for population modeling that are not available in peer-reviewed literature or in existing data, which represent informational gaps. Therefore, these demographic rates will need to be borrowed from related sturgeons or elicited from expert opinion.

\section{Strategy for Using Existing Models in the Effects Analysis}

No single tool exists that can be used for the EA. The conceptual life cycle model for pallid sturgeon described by Wildhaber and others (2011a) and the subsequent CEMs developed from that template (Jacobson and others, 2015) require a stage-based modeling approach. Although a number of age-based models using an annual time step have been developed previously, a stage-based population model will need to be developed that can accept survival inputs from quantitative versions of the CEMs. The stage-based model will likely incorporate a daily time step given the short duration of the early-life history stages represented in the CEMs. It should be noted that a short duration time step does not preclude using the demographic rates from previous models. These demographics rates can be used in a stage-based model; however, they will need to be modified to account for the time step used in the model. Overall, the process to develop CEMs and link them to a population model will be an iterative process; therefore, additional parameters and models that may potentially be useful in the process will be identified (or not) as the need arises.

\section{Review of Existing Data}

Databases identified in the course of this assessment include research, monitoring, genetic, and population-augmentation databases associated with pallid sturgeon restoration efforts. The databases 
vary in their complexity and in where they are located. In the following sections we describe these databases, the extent of their holdings, the sampling or statistical design, and an evaluation of their utility to the EA.

\section{Pallid Sturgeon Population Assessment Project}

The PSPAP is the primary fish monitoring element for the 2000 amended Biological Opinion (BiOp) for the Missouri River (U.S. Fish and Wildlife Service, 2000, 2003) and the Missouri River Recovery Program (MRRP). Data collected through the PSPAP are used to evaluate the ongoing pallid sturgeon propagation and population-augmentation management action (Reasonable and Prudent Alternative Element IV; RPA) and provide long-term assessments of fish metrics including population trends, survival, movement, distribution, and habitat use by pallid sturgeon and other target fishes (table 2). The USACE, as the action agency, is responsible for ensuring that these long-term assessment activities occur to meet $\mathrm{BiOp}$ required monitoring and evaluation. The Project is implemented through partnerships with state and Federal agencies already active on the Missouri River. The PSPAP also collects pallid sturgeon broodstock each spring for meeting the stocking levels identified by management biologists.

Table 2. River segments and bends sampled each year in the Missouri River and selected tributaries for the Pallid Sturgeon Population Assessment Project. Note that former segment 12 (Kansas River to Glasgow, Missouri was combined with segment 13 and eliminated (Welker and Drobish, 2012b).

\begin{tabular}{lc}
\hline \multicolumn{1}{c}{ Segment Number and Description (figs. 1 and 3) } & Randomly Selected River Bends \\
\hline 1 Fort Peck Dam to Milk River, Montana & 12 \\
2 Milk River to Wolf Point, Montana (Hwy 13 bridge) & 21 \\
3 Wolf Point to Yellowstone River, North Dakota (confluence) & 12 \\
4 Confluence to Headwaters, North Dakota (Lake Sakakawea) & 10 \\
5 Fort Randall Dam to Niobrara River, Nebraska (confluence) & combined with segment 5 \\
6 Confluence to Headwaters (Lewis and Clark Lake) & 12 \\
7 Gavins Point Dam to Lower Ponca Bend & 15 \\
8 Lower Ponca Bend to Platte River, Nebraska (confluence) & 20 \\
9 Platte River to the Kansas River, Kansas (confluence) & 10 \\
10 Kansas River to the Grand River, Missouri (confluence) & 3 \\
11 Kansas River from the highway 7 bridge to the confluence with & 11 \\
the Missouri River, Missouri & 14 \\
13 Grand River to Osage River, Missouri (confluence) & \\
\hline
\end{tabular}

The PSPAP objectives, sample design, and protocols have been developed and guided by the Project Delivery Team (PDT) that is composed of seven agency offices from the U.S. Fish and Wildlife Service (USFWS); Montana Fish, Wildlife and Parks (MtFWP); South Dakota Game, Fish, and Parks (SDGFP); Nebraska Game and Parks Commission (NGPC); and Missouri Department of Conservation (MDC). Independent review (Sustainable Ecosystems Institute, 2004) and assessments (Bryan and others, 2010; Schapaugh and Tyre, 2011; Wildhaber and others, 2011b) have also guided PSPAP development and direction. The PSPAP area encompasses the Missouri River from Fort Peck Dam, Mont. downstream to the confluence of the Missouri and Mississippi Rivers near St. Louis, Mo. and the lower reach of the Kansas River (fig. 1). Thirteen priority river segments are sampled through the PSPAP (fig. 3). 


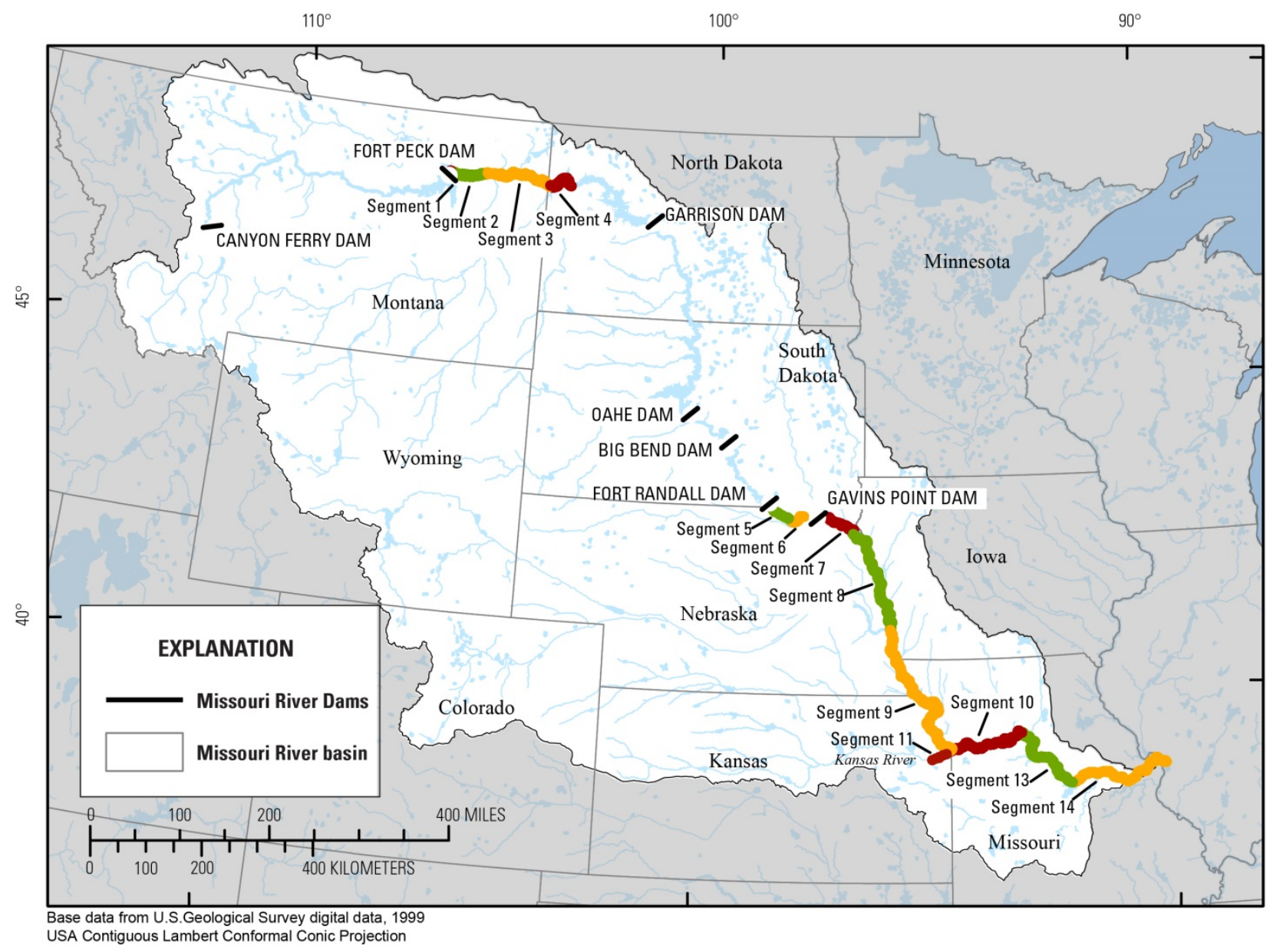

Figure 3. Map showing sampled segments of the Missouri River for the Pallid Sturgeon Population Assessment Project, 2014.

In addition to pallid sturgeon, a representative group of native Missouri River fishes is also monitored to detect improvements in the system as reflected by changes in the warm water benthic fish community. Project monitoring targets the following species: Scaphirhynchus albus (pallid sturgeon), Notropis stramineus (sand shiner), Macrhybopsis meeki (sicklefin chub), Sander canadensis (sauger), Scaphirhynchus platorynchus (shovelnose sturgeon), Hybognathus placitus (plains minnow), Hybognathus argyritis (western silvery minnow), Macrhybopsis hyostoma- formerly speckled chub Macrhybopsis aestivalis (shoal chub), Macrhybopsis gelida (sturgeon chub) and Cycleptus elongatus (blue sucker).

Objectives for the PSPAP were developed to meet requirements in the 2003 Biological Opinion:

1. Evaluate trends in pallid sturgeon population abundance, distribution, and habitat use throughout the Missouri River system.

2. Evaluate survival, growth, and habitat use of stocked pallid sturgeon in the Missouri River system.

3. Document and evaluate pallid sturgeon reproduction and recruitment in the Missouri River system.

4. Evaluate current and long-term trends in native Missouri River fish species abundance, distribution, and habitat usage, with emphasis on warm water benthic fish community. 


\section{Geographic Scope}

The PSPAP area encompasses the Missouri River at Fort Peck Dam, Mont. downstream to the confluence of the Missouri and Mississippi Rivers near St. Louis, Mo. and the lower reach of the Kansas River (fig. 3). The BiOp divides the PSPAP area into river and reservoir segments and assigns high, moderate, or low priority management action to these segments for the pallid sturgeon. The focus of the PSPAP is the high-priority management-action segments. The segments identified as moderate or low priority for pallid sturgeon are categorized as reservoirs or transitional zones between rivers and reservoirs (U.S. Fish and Wildlife Service, 2000).

\section{Sample Design}

Fish and habitat data collections within the 13 river segments began in 2003 with full implementation of standardized sampling in all high-priority segments in 2006 (Welker and Drobish, 2012b). The PSPAP uses a three-tiered hierarchical habitat classification system (fig. 4) that allows for both general and specific categorization for sampling to serve the needs for biological- and physicaldata collection efforts. A river bend (bend) serves as the basic sampling unit (replicate) within each river segment. A bend comprises three continuous macrohabitats, an outside bend (main channel), an inside bend (main channel), and a channel crossover (main channel). Within a segment, a minimum of 25.2 percent of all bends are sampled in a year. The number of bends required within each segment is outlined in table 2. Within a bend, 10 potential discrete macrohabitats could occur beyond the three continuous macrohabitats (that is, large and small tributary mouths, confluences, large and small secondary connected channels, nonconnected secondary channels, deranged, braided, dendritic, and dam tailwater) (fig. 4). All available macrohabitats are subsampled within a randomly selected bend.

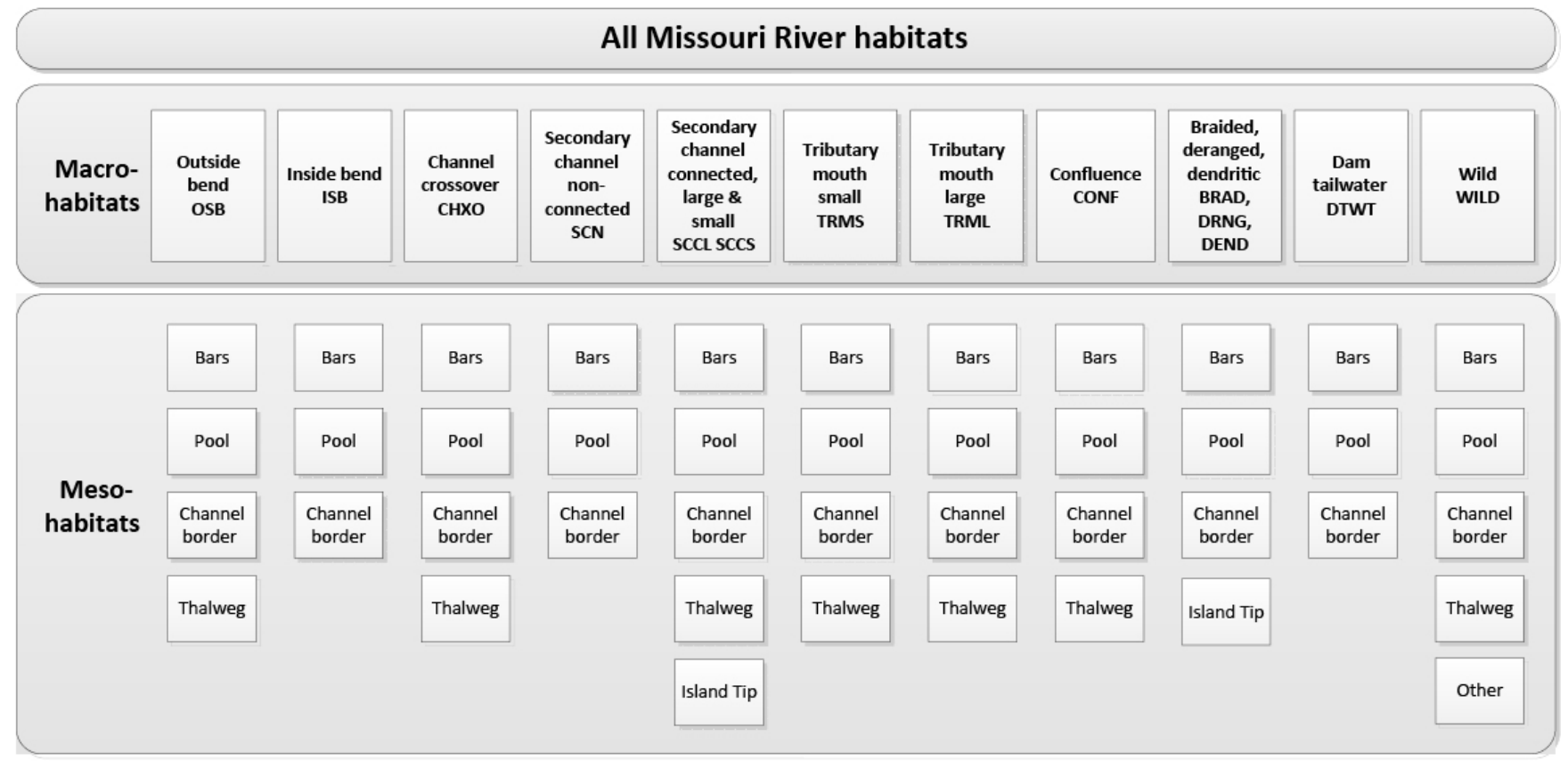

Figure 4. Diagram showing the three-tiered hierarchical habitat classification system utilized by the Pallid Sturgeon Population Assessment Project. 
Every sampling year includes two sampling seasons, which begin in autumn with a sturgeon focused season (sturgeon season, ST) and followed by a fish community focused (fish community season, FC) season. Sturgeon season conditionally begins when water temperature decreases to $12.8{ }^{\circ} \mathrm{C}$ at which point it is believed that gill nets and trot lines can be utilized during sampling with minimal stress to the pallid sturgeon. The ST ends on June 30. FC begins July 1 and ends October 31.

A variety of fish and habitat metrics are measured through the PSPAP. For each pallid sturgeon, capture data that are collected include: length and weight, morphological (meristics), genetic, marking (Passive Integrated Transponder (PIT) tags, elastomer tags, or scute removal), habitat at capture location (depth, velocity, turbidity, and temperature), and location. Some of these data are also collected for the other target fish species.

\section{Pallid Sturgeon Population Assessment Project Database}

The Pallid Sturgeon Population Assessment Project Database (PSPAP-D) is an Oracle ${ }^{\circledR}$ relational database that organizes tabular fish and habitat data collected through several projects. Contact for the database is the PSPAP-D Manager, Kyle Winders, Missouri Department of Conservation, Chillicothe, Mo. The process for requesting data is outlined in Appendix C of the PSPAP Guiding Document (Welker and Drobish, 2012b); the process requires an application and agreement by a majority of the PSPAP team.

The PSPAP-D houses data for five additional projects: Project 2-Habitat and Assessment Monitoring Project; Project 3 - Chute Study-Mitigation Project; Project 4-Spring Rise Evaluation Project; Project 5-Dalbey Bottoms Project; and Project 6-Pallid Sturgeon Catchability Project. Table 3 documents the number of habitat, fish, and pallid sturgeon subsamples for each project. Data collection procedures for Projects 2 and 3 followed Drobish (2008).

\section{Brief Description of the Datasets for Each Project}

Project 1-Pallid Sturgeon Population Assessment Project

As previously described, numerous fish and habitat metrics are measured in the segments and habitats sampled through the PSPAP. Although not an in-depth description of the data collected through the PSPAP, brief descriptions of the database fields for the PSPAP are provided in appendix B. The data collected and the sampling protocols used for the PSPAP are described in detail in Welker and Drobish (Welker and Drobish, 2012a, b).

Project 2-Habitat and Assessment Monitoring Project

See description in next section. The PSPAP database houses HAMP biological data 2005-12. Project 3-Chute Study-Mitigation Project

Four resource agencies (Iowa Department of Natural Resources (IDNR), NGPC, MDC, and USFWS at Columbia, Mo.) monitored fish communities of selected off-channel aquatic habitat sites that were constructed through mitigation for the Missouri River Bank Stabilization and Navigation Project. The NGPC also collected physical-habitat information from secondary channels that were selected for biological monitoring in the channelized section of Missouri River above Kansas City. Sixteen sites were monitored during 2005-09 to meet the following objectives:

1. Collect a selected group of biological indicators (catch per unit effort (CPUE), length frequency, condition based on relative weight, species richness, species diversity, and community similarity) for different life stages (defined by length in the published literature) on a select 
group of species or species groups (native, species of concern, sport, prey, and invasive) using standard collection methods to assess the biological performance of off-channel sites.

2. Describe habitat use (including depth, velocity, and substrate) by life stage of selected fish species or species groups.

3. Collect extensive physical-habitat information to be able to describe monthly and seasonal habitat conditions of each site and to compare among sites.

Project 4-Spring Rise Evaluation Project

Project 4 was designed to evaluate the timing of shovelnose and pallid sturgeon spawning as measured through egg and blood-related meristics.

Project 5-Dalbey Bottoms Project

Trotlines and trawls (push trawl and stern trawl) were deployed in various habitats at the proposed construction site for the Dalbey Bottoms chute near Dalbey, Kansas (fig. 5). Sampling occurred in the main channel of the Missouri River at the proposed site to evaluate the preconstruction and postconstruction effect on the fish community and to assess the ecological effects of a constructed chute on pallid sturgeon and other native Missouri River fishes. As of the date of this report (2015), postconstruction sampling and assessment have not occurred.

Project 6-Pallid Sturgeon Catchability Project

Ultrasonic tags were placed into two size categories (Shuman and others, 2006) of juvenile pallid sturgeon, stock-quality (330-629 mm) and quality-preferred (630-839 mm), to assess detectability, catchability, and post-handling mortality in the unchannelized Missouri River. Fish collecting gears used by the PSPAP were deployed at locations of tagged pallid sturgeon to assess the following objectives:

1. Determine the capture/detection probability of pallid sturgeon in active and passive gears currently used in the PSPAP,

2. Determine the conditional capture probability (catchability) of pallid sturgeon in active gears currently used in the PSPAP, and

3. Estimate post-handling survival of age-1plus hatchery propagated pallid sturgeon captured with currently used PSPAP standardized gear.

\section{Evaluation and Contribution to Effects Analysis}

The PSPAP collects population-level data (size, growth, survival, and distribution) that may be used to parameterize stage-based population models for pallid sturgeon under present conditions. The data from the PSPAP have already been used to quantify certain population metrics such as size (Steffensen and others, 2012), growth (Shuman and others, 2011), and survival (Hadley and Rotella, 2009; Rotella, 2012; Steffensen and others, 2013a; Wildhaber and others, 2015b) in both the Upper and Lower Missouri Rivers. The EA will depend heavily on PSPAP data and reports to improve understanding of habitat selection, for initial parameterization of a population-level model for pallid sturgeon, and to prioritize life stages for modeling management effects on survival. 
Table 3. The number of subsamples for each project housed in the Pallid Sturgeon Population Assessment Database

\begin{tabular}{|c|c|c|c|c|c|}
\hline Project & Name & $\begin{array}{c}\text { Habitat } \\
\text { Subsamples }\end{array}$ & $\begin{array}{c}\text { Fish } \\
\text { Subsamples }\end{array}$ & $\begin{array}{c}\text { Pallid Sturgeon } \\
\text { Subsamples }\end{array}$ & Sample Years \\
\hline 1 & $\begin{array}{l}\text { Pallid Sturgeon } \\
\text { Population } \\
\text { Assessment }\end{array}$ & 98,907 & 973,090 & 9,225 & 2003-Ongoing. \\
\hline 2 & $\begin{array}{l}\text { Chute Study- } \\
\text { Mitigation } \\
\text { Project }\end{array}$ & 19,957 & 310,458 & 232 & 2005-09. \\
\hline 3 & $\begin{array}{l}\text { Habitat } \\
\text { Assessment } \\
\text { and } \\
\text { Monitoring } \\
\text { Project }\end{array}$ & 17,990 & 151,461 & 26 & 2005-12. \\
\hline 4 & $\begin{array}{l}\text { Spring Rise } \\
\text { Evaluation } \\
\text { Project }\end{array}$ & 4,781 & 19,789 & 75 & 2006-09. \\
\hline 5 & $\begin{array}{l}\text { Dalbey Bottoms } \\
\text { Project }\end{array}$ & 189 & 2,796 & 21 & 2009. \\
\hline 6 & $\begin{array}{l}\text { Pallid Sturgeon } \\
\text { Catchability } \\
\text { Project }\end{array}$ & 93 & 106 & 19 & 2013-Ongoing. \\
\hline
\end{tabular}

\section{Habitat Assessment and Monitoring Project}

The primary goal of the HAMP is to assess physical and biological responses to habitat modification in the channelized portion of the Lower Missouri River, downstream of Ponca, Nebr. (fig. 5), for targeted fish species. Examples include the endangered pallid sturgeon (Scaphirhynchus albus), sicklefin chub (Macrhybopsis meeki), sturgeon chub (Macrhybopsis gelida), speckled chub (Macrhybopsis aestivalis), plains minnow (Hybognathus placitus), western silvery minnow (Hybognathus argyritis), blue sucker (Cycleptus elongatus), and sauger (Sander canadensis). The HAMP was initiated in 2004-06 by an interagency collaboration of representatives from the IDNR, MDC, NGPC, SDGFP, University of Missouri, USACE, USFWS, and USGS to evaluate habitat modifications designed to increase shallow, slow water habitat within the main channel of the Missouri River.

Specific objectives of the HAMP are summarized below:

1. To monitor and evaluate temporal trends in physical habitat diversity in physically modified habitat relative to unmodified habitats documented in control locations;

2. To monitor and evaluate temporal trends of target fish species population characteristics (measured as relative abundance, presence/absence, or condition) in physically modified habitat relative to unmodified habitat;

3. To evaluate data for effectiveness and design that would help guide future channel reconfiguration efforts.

From 2006-09, a before-after-control-impact (BACI) study design was used to evaluate the effects of habitat alteration (including dike notching, bank notching, side-channel chutes) on fish communities (Schapaugh and others, 2010). Following this evaluation, shorter-duration studies have examined power to detect trends in fish populations (Bryan and others, 2010), fish communities and associated habitat (Schloesser and others, 2012), fish abundance related to shallow-water habitat (SWH) 
availability (Ridenour and others, 2009; Ridenour and others, 2011b), habitat related to prey production (Sampson and Hall, 2011), flood plain and water-quality sampling (Morris and others, 2013; Gosch and others, 2014), chute habitat and use evaluation (Gosch and others, 2015), and SWH usage (Gemeinhardt and others, 2015).

An independent science review team examined the HAMP in 2004 and concluded that, although the project goals were feasible, it was unclear whether the statistical design was sufficient to detect trends and responses to habitat modifications (Sustainable Ecosystems Institute, 2005). Numerous annual reports from various agencies were written that summarize specific numbers of gears used and fish species caught by year (see references cited list). An evaluation by Schapaugh and others (2010) used biological data from the annual reports to analyze information value from the HAMP BACI design (discussed in the section, "Biological Assessments”).

The HAMP conceptually includes field-based monitoring and evaluation of physical habitat features and biological data. The study plan is designed for evaluation of habitat modification effectiveness determined by comparison of data from modified and unmodified habitat in the Lower Missouri River. The project area includes 44 river bends from river mile (RM) 750 near Ponca, Nebr. downstream to the confluence of the Missouri and Mississippi Rivers near St. Louis, Mo. (figs. 2, 3, and 5; table 2).

\section{Biological Assessments}

From 2004-09, pallid sturgeon and other target species were monitored to evaluate changes in relative abundance between habitat-modified and unmodified river bends. A BACI study design was used to evaluate the potential effects of habitat alteration (dominantly dike notching) on fish communities. The report from the assessment (Schapaugh and others, 2010) cited the HAMP as an excellent design to achieve active adaptive management; however, the report also documented that assumptions underlying the BACI designs were not being met under real-world conditions, and, therefore, the ability to detect effects of SWH was limited. In particular, the authors reported that the actions of dike notching and channel widening did not result in detectable changes in the fish community. The authors suggested that specific hypotheses about mechanisms of change associated with changes in habitat and fish production need to be addressed. Several hypotheses that may explain the results of this study were presented:

1. SWH is not limiting, therefore, increasing SWH has no effect on target species.

2. Biological responses to habitat changes may take a long time to be observable, more time than was allowed in these before/after intervals.

3. Physical conditions of modified habitats may take a long time to fully develop for their intended purpose, thereby imparting an additional lag time to biological responses.

4. Inherent system variability may limit the ability to detect changes.

5. Expected benefits of habitat modification may not be realized at the expected location, but rather at downstream locations.

6. The amount of habitat modification effort may be insufficient to detect a response.

Similarly, Schloesser and others (2012) evaluated fish communities at modified and unmodified habitats in the Lower Missouri River. Few differences in species richness or diversity were observed between modified and natural habitats. The authors reported that dike notching did not result in increased abundance or occupancy of most Missouri River fishes. 
Bryan and others (2010) conducted an analysis to evaluate the statistical power of the HAMP using a normal-linear mixed model with variance based on the first year of sampling. The use of multiple sampling gears to differentiate habitat treatment differences for a variety of fish species is a strength of the HAMP. The authors suggested that preliminary data and results were appropriate to the HAMP BACI study design. Because physical habitat and biological responses to habitat modification could take a long time to be observed, Ridenour and others (2011a) attempted to evaluate fish communities between "end-state” habitats (that is, river reaches approximately 20 years after habitat modification) and "non-endpoint" sites (that is, control river reaches that lack, or have minimal, habitat modification). Species composition was similar between both habitats but mean relative abundance of fish was larger at end-state sites.

In addition to fish community comparisons among habitat types, benthic invertebrates were evaluated in selected cases. Sampson and Hall (2011) examined invertebrate spatial and temporal variability among habitat types, identified efficient sampling methods, identified sampling pitfalls, and estimated sampling costs for invertebrate assessments. Invertebrate communities in backwater habitats tended to have higher densities and were composed of taxa typically characteristic for lentic environments. In flow-through side-channel habitats, invertebrate abundance was less dense and was composed of taxa typically characteristic for lotic environments.

Extensive flooding in 2011 along the Missouri River provided an opportunity to evaluate flood plain inundation and the effect on fish reproduction, fish recruitment, and prey response using HAMP data (T. Gemeinhardt, USACE, written commun., 2014). Multiple sites were sampled every two weeks when sites were inundated. Sampling focused on larval and young-of-year fish, zooplankton, and benthic invertebrates. Analysis of the invertebrate data has been completed (Gosch and others, 2014); however, analyses of other data are in progress at the time of this report (2015).

From 2012 to present, HAMP efforts have been modified to de-emphasize the previous BACI design and to focus on specific hypotheses relating SWH and life-stage processes of larval and youngof-year pallid sturgeon (T. Gemeinhardt, USACE, written commun., 2014). Recently, chute habitats have been compared to main stem habitats to evaluate differences in depth and water velocity (Gosch and others, 2015). Seven chutes were selected and sampled twice per month from May to September with a variety of gears. A total of 165 age- 0 sturgeon (undifferentiated shovelnose and pallid) was caught in both years. Preliminary observations suggest that restored chutes may provide important habitat to age-0 sturgeon. Further, sturgeon were sampled from deeper ( $>1.5$ meters [m]) and faster ( $>0.5$ meters per second $[\mathrm{m} / \mathrm{s}]$ ) water than sites where sturgeon were not caught, which is similar to results reported by Ridenour and others (Ridenour and others, 2011b).

HAMP biological data 2006-12 are incorporated in the PSPAP database (see the section, "Habitat Assessment and Monitoring Project”). Data collected since 2012 are housed with the HAMP manager (Todd Gemeinhardt, USACE, Kansas City District, Kansas City, Mo.).

\section{Physical Assessments}

Numerous physical-habitat surveys have been conducted as part of the HAMP by the Kansas City (Kansas City, Mo.) and Omaha Districts (Omaha, Nebr.) of the USACE; the Kansas City District covers the Lower Missouri River from RM 0 to 500 (fig. 5) and the Omaha District covers RM 500-811 (fig. 5). At least 138 reach-scale surveys (and associated datasets) were conducted by several groups including the USACE, Eisenbraun Inc., or USGS (tables 4-7). These individual surveys vary widely in location, scale, resolution, and location. Within the districts, three main types of habitat were surveyed, including main channels, chutes, and backwaters. Sampling years span from 2002 to 2013. Surveys were conducted with single-beam bathymetry, single beam plus Trimble Virtual Reference Station 
(VRS ${ }^{\mathrm{TM}}$ ) System location, multibeam bathymetry, sediment-sample collection, acoustic Doppler current profiles (ADCP), and land surveys. In addition, some two-dimensional hydrodynamic modeling was conducted in the Kansas City District to inventory habitat area.

Both districts have carried out periodic physical-habitat assessments. The main channel of the Missouri River in the Kansas City District has been sporadically surveyed from 2005 to 2013 (table 4). Typically, single-beam bathymetry was used. Chute habitats in the Kansas City District (number of sites was about 15 sites) were surveyed periodically from 2006 to 2013 using single-beam bathymetry, single beam plus VRS, land surveys, and multibeam bathymetry (table 5). Two-dimensional modeling was done for seven sites in the Kansas City District from 2002 to 2006 with data compiled from single-beam bathymetry, multi-beam bathymetry, and ADCP methods (table 6). In the Omaha district, 46 locations have been surveyed that include backwater, chute (off channel), and river bend (channel) habitats. Single beam bathymetry, multi-beam bathymetry, sediment sampling, and ADCP surveys were conducted from 2005 to 2013. Physical survey data are housed with the Hydrology and Hydraulic Branches of the Omaha and Kansas City Districts.

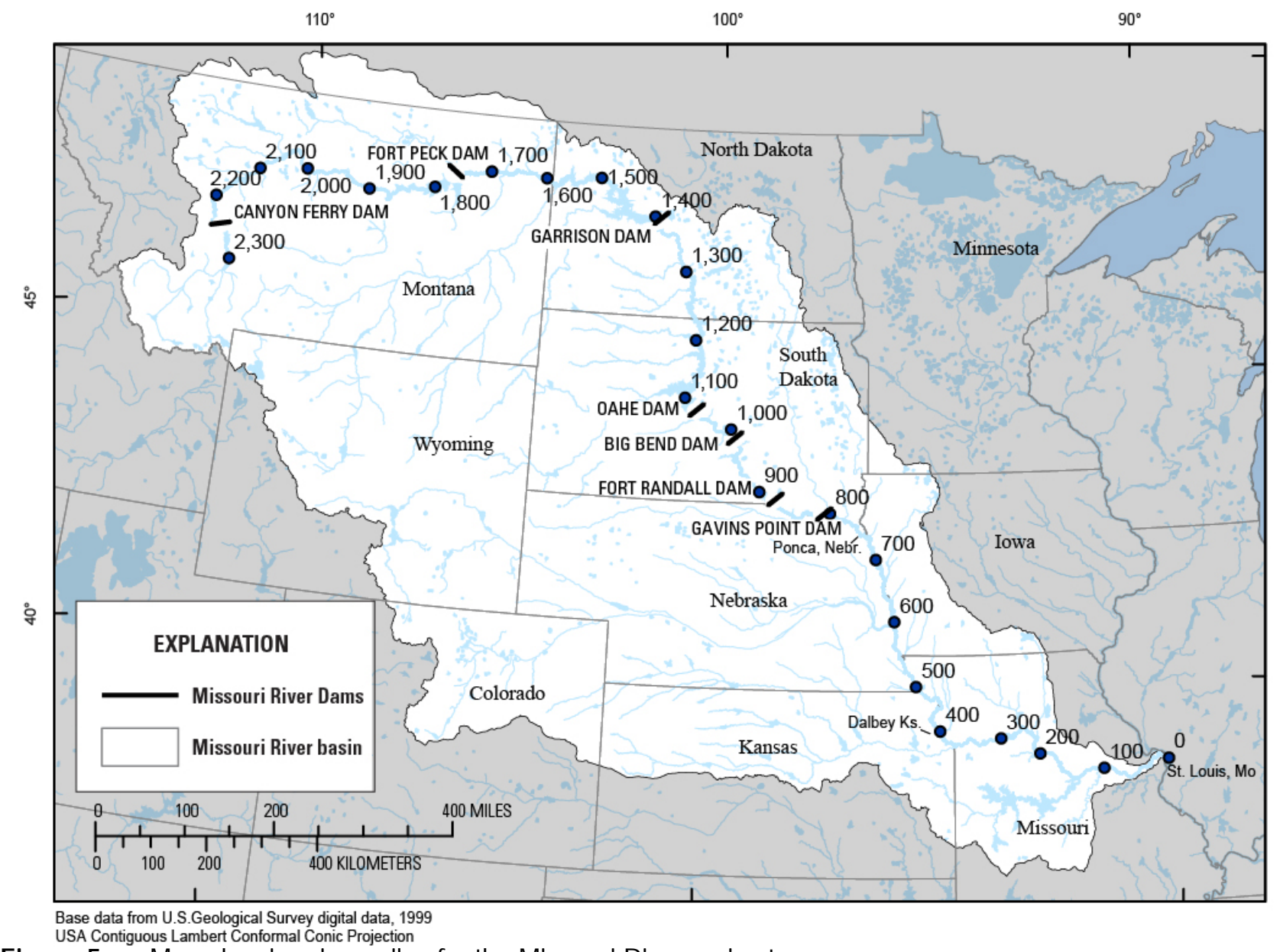

Figure 5. Map showing river miles for the Missouri River main stem. 
Table 4. List of datasets for physical-habitat surveys that have been conducted as part of the Habitat Assessment and Monitoring Program in the main channel of the Kansas City District Missouri River [USACE-NWK refers to the U.S. Army Corps of Engineers, Kansas City District. Source of data is T. Gemeinhardt, U.S. Army Corps of Engineers, written commun., 2014]

\begin{tabular}{|c|c|c|c|c|}
\hline Dataset name & Year & Season/Month/Date & Collection Method & Agency/Contractor \\
\hline Searcy & 2005 & - & HYPACK-single beam & USACE-NWK. \\
\hline Baltimore & 2006 & August & HYPACK-single beam & USACE-NWK. \\
\hline Boyer & 2006 & - & HYPACK-single beam & USACE-NWK. \\
\hline Camden & 2006 & - & HYPACK-single beam & USACE-NWK. \\
\hline Creve Coeur & 2006 & - & HYPACK-single beam & USACE-NWK. \\
\hline Dallas & 2006 & September & HYPACK-single beam & USACE-NWK. \\
\hline Doziers Bend & 2006 & September & HYPACK-single beam & USACE-NWK. \\
\hline Fishing River & 2006 & - & HYPACK-single beam & USACE-NWK. \\
\hline Malta & 2006 & - & HYPACK-single beam & USACE-NWK. \\
\hline Marion & 2006 & - & HYPACK-single beam & USACE-NWK. \\
\hline Nemaha & 2006 & September & HYPACK-single beam & USACE-NWK. \\
\hline Pickney & 2006 & September & HYPACK-single beam & USACE-NWK. \\
\hline Rocheport & 2006 & - & HYPACK-single beam & USACE-NWK. \\
\hline Sni & 2006 & August & HYPACK-single beam & USACE-NWK. \\
\hline Tarkio & 2006 & - & HYPACK-single beam & USACE-NWK. \\
\hline Washington & 2006 & - & - & - \\
\hline $\begin{array}{l}2007 \text { HAMP Bend } \\
\text { Hydrosurvey }\end{array}$ & 2007 & summer/fall & HYPACK-single beam & Eisenbraun Contract. \\
\hline 2007 Hydrosurvey & 2007 & summer/fall & HYPACK-single beam & Eisenbraun Contract. \\
\hline 2008 Hydrosurvey & 2008 & summer/fall & HYPACK-single beam & Eisenbraun Contract. \\
\hline 2009 Hydrosurvey & 2009 & summer/fall & HYPACK-single beam & Eisenbraun Contract. \\
\hline $\begin{array}{l}2011 \text { (June) Flood Hydrosurvey } \\
\text { St. Joe to Waverly }\end{array}$ & 2011 & June & HYPACK-single beam & USACE-NWK. \\
\hline \multirow[t]{11}{*}{$\begin{array}{l}2011 \text { Flood Hydrosurvey KC } \\
\text { Reach }\end{array}$} & 2011 & June 09 & HYPACK-single beam & USACE-NWK. \\
\hline & 2011 & August & HYPACK-single beam & USACE-NWK. \\
\hline & 2011 & November & HYPACK-single beam & USACE-NWK. \\
\hline & 2011 & June 13 & HYPACK-single beam & USACE-NWK. \\
\hline & 2011 & June 28 & HYPACK-single beam & USACE-NWK. \\
\hline & 2011 & July 07 & HYPACK-single beam & USACE-NWK. \\
\hline & 2011 & July 14 & HYPACK-single beam & USACE-NWK. \\
\hline & 2011 & Aug. 09 & HYPACK-single beam & USACE-NWK. \\
\hline & 2011 & Aug. 31 & HYPACK-single beam & USACE-NWK. \\
\hline & 2011 & Sept. 22 & HYPACK-single beam & USACE-NWK. \\
\hline & 2011 & Nov. 09 & HYPACK-single beam & USACE-NWK. \\
\hline 2012 Hydrosurvey & 2012 & summer/fall & HYPACK-single beam & Eisenbraun Contract. \\
\hline 2013 Hydrosurvey & 2013 & summer/fall & HYPACK-single beam & Eisenbraun Contract. \\
\hline
\end{tabular}


Table 5. List of datasets for physical habitat surveys that have been conducted as part of the Habitat Assessment and Monitoring Program in chute habitats of the Kansas City District Missouri River

[VRS refers to the Virtual Reference System. USACE-NWK refers to the U.S. Army Corps of Engineers, Kansas City District. Source of data is T. Gemeinhardt, U.S. Army Corps of Engineers, written commun., 2014]

\begin{tabular}{|c|c|c|c|c|c|}
\hline Location & Dataset name & Year & $\begin{array}{l}\text { Season or } \\
\text { Month }\end{array}$ & Survey type & Agency/Contractor \\
\hline $\begin{array}{l}\text { Byran } \\
\text { Island }\end{array}$ & $\begin{array}{l}2010 \text { Flood Bryan } \\
\text { Hydrosurvey }\end{array}$ & 2010 & summer & $\begin{array}{l}\text { HYPACK-single } \\
\text { beam }\end{array}$ & USACE-NWK. \\
\hline $\begin{array}{l}\text { Byran } \\
\text { Island }\end{array}$ & 2013 Bryan Hydrosurvey & 2013 & summer/fall & $\begin{array}{l}\text { HYPACK-single } \\
\text { beam }\end{array}$ & $\begin{array}{l}\text { Eisenbraun } \\
\text { Contract. }\end{array}$ \\
\hline Cranberry & $\begin{array}{l}2010 \text { Flood Cranberry } \\
\text { Hydrosurvey }\end{array}$ & 2010 & summer & $\begin{array}{l}\text { HYPACK-single } \\
\text { beam }\end{array}$ & USACE-NWK. \\
\hline Cranberry & $\begin{array}{l}2010 \text { Flood Small Baltimore } \\
\text { Hydrosurvey }\end{array}$ & 2010 & summer & $\begin{array}{l}\text { HYPACK-single } \\
\text { beam }\end{array}$ & USACE-NWK. \\
\hline Cranberry & 2013 Cranberry & 2013 & summer/fall & $\begin{array}{l}\text { HYPACK-single } \\
\text { beam }\end{array}$ & $\begin{array}{l}\text { Eisenbraun } \\
\text { Contract. }\end{array}$ \\
\hline Cranberry & 2013 Small Baltimore & 2013 & summer/fall & $\begin{array}{l}\text { HYPACK-single } \\
\text { beam }\end{array}$ & $\begin{array}{l}\text { Eisenbraun } \\
\text { Contract. }\end{array}$ \\
\hline Dalbey & 2013 Dalbey Bottoms & 2013 & June & $\begin{array}{l}\text { HYPACK-single } \\
\text { beam }\end{array}$ & USACE-NWK. \\
\hline $\begin{array}{l}\text { Franklin } \\
\text { Island }\end{array}$ & $\begin{array}{l}2010 \text { Flood Franklin } \\
\text { Hydrosurvey }\end{array}$ & 2010 & summer & $\begin{array}{l}\text { HYPACK-single } \\
\text { beam }\end{array}$ & USACE-NWK. \\
\hline $\begin{array}{r}\text { Franklin } \\
\text { Island }\end{array}$ & 2013 Franklin Island & 2013 & summer/fall & $\begin{array}{l}\text { HYPACK-single } \\
\text { beam }\end{array}$ & $\begin{array}{l}\text { Eisenbraun } \\
\text { Contract. }\end{array}$ \\
\hline Hodge & $\begin{array}{l}2010 \text { Flood Hodge } \\
\text { Hydrosurvey }\end{array}$ & 2010 & summer & $\begin{array}{l}\text { HYPACK-single } \\
\text { beam }\end{array}$ & USACE-NWK. \\
\hline Hodge & 2013 Hodge & 2013 & summer/fall & $\begin{array}{l}\text { HYPACK-single } \\
\text { beam }\end{array}$ & $\begin{array}{l}\text { Eisenbraun } \\
\text { Contract. }\end{array}$ \\
\hline Howell & 2013 Howell Hydrosurvey & 2013 & summer/fall & $\begin{array}{l}\text { HYPACK-single } \\
\text { beam }\end{array}$ & $\begin{array}{l}\text { Eisenbraun } \\
\text { Contract. }\end{array}$ \\
\hline $\begin{array}{l}\text { Jameson } \\
\text { Island }\end{array}$ & $\begin{array}{l}2006 \text { February Jameson } \\
\text { Survey }\end{array}$ & 2006 & February & land survey & USACE-NWK. \\
\hline $\begin{array}{l}\text { Jameson } \\
\text { Island }\end{array}$ & $\begin{array}{l}2007 \text { September Jameson } \\
\text { Survey }\end{array}$ & 2007 & September & land survey & USACE-NWK. \\
\hline $\begin{array}{r}\text { Jameson } \\
\text { Island }\end{array}$ & $\begin{array}{l}2009 \text { January Jameson } \\
\text { Survey }\end{array}$ & 2009 & January & land survey & USACE-NWK. \\
\hline $\begin{array}{r}\text { Jameson } \\
\text { Island }\end{array}$ & $\begin{array}{l}2010 \text { Flood Jameson } \\
\text { Hydrosurvey }\end{array}$ & 2010 & summer & $\begin{array}{l}\text { HYPACK-single } \\
\text { beam }\end{array}$ & USACE-NWK. \\
\hline $\begin{array}{l}\text { Jameson } \\
\text { Island }\end{array}$ & $\begin{array}{l}2011 \text { June Jameson Island } \\
\text { Hydrosurvey }\end{array}$ & 2011 & June & $\begin{array}{l}\text { HYPACK-single } \\
\text { beam }\end{array}$ & USACE-NWK. \\
\hline $\begin{array}{l}\text { Jameson } \\
\text { Island }\end{array}$ & $\begin{array}{l}2012 \text { Feb Jameson Island } \\
\text { Survey }\end{array}$ & 2012 & February & $\begin{array}{l}\text { HYPACK-single } \\
\text { beam+VRS }\end{array}$ & USACE-NWK. \\
\hline $\begin{array}{l}\text { Jameson } \\
\text { Island }\end{array}$ & $\begin{array}{l}2012 \text { July Jameson Island } \\
\text { Survey }\end{array}$ & 2012 & July & $\begin{array}{l}\text { HYPACK-single } \\
\text { beam+VRS }\end{array}$ & USACE-NWK. \\
\hline $\begin{array}{r}\text { Jameson } \\
\text { Island }\end{array}$ & $\begin{array}{l}2013 \text { Jameson Island } \\
\text { Hydrosurvey }\end{array}$ & 2013 & summer/fall & $\begin{array}{l}\text { HYPACK-single } \\
\text { beam }\end{array}$ & $\begin{array}{l}\text { Eisenbraun } \\
\text { Contract. }\end{array}$ \\
\hline $\begin{array}{l}\text { Jameson } \\
\text { Island }\end{array}$ & 2013 July Jameson Island & 2013 & July & $\begin{array}{l}\text { HYPACK-single } \\
\text { beam }\end{array}$ & USACE-NWK. \\
\hline $\begin{array}{l}\text { Johnson } \\
\text { Island }\end{array}$ & $\begin{array}{l}2010 \text { Flood Johnson } \\
\text { Hydrosurvey }\end{array}$ & 2010 & summer & $\begin{array}{l}\text { HYPACK-single } \\
\text { beam }\end{array}$ & USACE-NWK. \\
\hline $\begin{array}{r}\text { Johnson } \\
\text { Island }\end{array}$ & $\begin{array}{l}2012 \text { October Johnson } \\
\text { Hydrosurvey }\end{array}$ & 2012 & October & $\begin{array}{l}\text { HYPACK-single } \\
\text { beam }\end{array}$ & USACE-NWK. \\
\hline $\begin{array}{r}\text { Johnson } \\
\text { Island }\end{array}$ & 2013 Johnson Hydrosurvey & 2013 & summer/fall & $\begin{array}{l}\text { HYPACK-single } \\
\text { beam }\end{array}$ & $\begin{array}{l}\text { Eisenbraun } \\
\text { Contract. }\end{array}$ \\
\hline
\end{tabular}


Table 5. List of datasets for physical habitat surveys that have been conducted as part of the Habitat Assessment and Monitoring Program in chute habitats of the Kansas City District Missouri River-Continued

\begin{tabular}{|c|c|c|c|c|c|}
\hline Location & Dataset name & Year & $\begin{array}{c}\text { Season or } \\
\text { Month }\end{array}$ & Survey type & Agency/Contractor \\
\hline $\begin{array}{l}\text { Johnson } \\
\text { Island }\end{array}$ & $\begin{array}{l}2013 \text { July Johnson } \\
\text { Hydrosurvey }\end{array}$ & 2013 & July & $\begin{array}{c}\text { HYPACK-single } \\
\text { beam }\end{array}$ & USACE-NWK. \\
\hline Lisbon & $\begin{array}{l}2010 \text { Flood Lisbon } \\
\text { Hydrosurvey }\end{array}$ & 2010 & summer & $\begin{array}{l}\text { HYPACK-single } \\
\text { beam }\end{array}$ & USACE-NWK. \\
\hline Lisbon & 2013 Lisbon Chute & 2013 & summer/fall & $\begin{array}{l}\text { HYPACK-single } \\
\text { beam }\end{array}$ & Eisenbraun Contract. \\
\hline Littles Island & $\begin{array}{l}2010 \text { Flood Littles } \\
\text { Hydrosurvey }\end{array}$ & 2010 & summer & $\begin{array}{l}\text { HYPACK-single } \\
\text { beam }\end{array}$ & USACE-NWK. \\
\hline Littles Island & 2013 Littles Hydrosurvey & 2013 & $\begin{array}{l}\text { summer/ } \\
\text { fall }\end{array}$ & $\begin{array}{l}\text { HYPACK-single } \\
\text { beam }\end{array}$ & Eisenbraun Contract. \\
\hline Lunch Island & $\begin{array}{l}2010 \text { Flood Lunch } \\
\text { Hydrosurvey }\end{array}$ & 2010 & summer & $\begin{array}{l}\text { HYPACK-single } \\
\text { beam }\end{array}$ & USACE-NWK. \\
\hline Lunch Island & 2013 Lunch Island & 2013 & $\begin{array}{l}\text { summer/ } \\
\text { fall }\end{array}$ & $\begin{array}{l}\text { HYPACK-single } \\
\text { beam }\end{array}$ & Eisenbraun Contract. \\
\hline $\begin{array}{l}\text { Overton } \\
\text { North }\end{array}$ & $\begin{array}{l}2008 \text { Overton North } \\
\text { Multibeam Survey }\end{array}$ & 2008 & October & multibeam survey & USACE-NWK. \\
\hline $\begin{array}{l}\text { Overton } \\
\text { North }\end{array}$ & $\begin{array}{l}2010 \text { Flood Overton } \\
\text { North Hydrosurvey }\end{array}$ & 2010 & summer & $\begin{array}{c}\text { HYPACK-single } \\
\text { beam }\end{array}$ & USACE-NWK. \\
\hline $\begin{array}{l}\text { Overton } \\
\text { North }\end{array}$ & $\begin{array}{l}2012 \text { Overton North } \\
\text { Survey }\end{array}$ & 2012 & July & $\begin{array}{l}\text { HYPACK-single } \\
\text { beam+VRS }\end{array}$ & USACE-NWK. \\
\hline $\begin{array}{l}\text { Overton } \\
\text { North }\end{array}$ & $\begin{array}{l}2013 \text { Overton North } \\
\text { Hydrosurvey }\end{array}$ & 2013 & $\begin{array}{l}\text { summer/ } \\
\text { fall }\end{array}$ & $\begin{array}{l}\text { HYPACK-single } \\
\text { beam }\end{array}$ & Eisenbraun Contract. \\
\hline $\begin{array}{l}\text { Pelican } \\
\text { Island }\end{array}$ & $\begin{array}{l}2010 \text { Flood Pelican } \\
\text { Hydrosurvey }\end{array}$ & 2010 & summer & $\begin{array}{l}\text { HYPACK-single } \\
\text { beam }\end{array}$ & USACE-NWK. \\
\hline $\begin{array}{l}\text { Pelican } \\
\text { Island }\end{array}$ & $\begin{array}{l}2013 \text { Aug Pelican } \\
\text { Hydrosurvey }\end{array}$ & 2013 & August & $\begin{array}{l}\text { HYPACK-single } \\
\text { beam }\end{array}$ & USACE-NWK. \\
\hline $\begin{array}{l}\text { Pelican } \\
\text { Island }\end{array}$ & $\begin{array}{l}2013 \text { May Pelican } \\
\text { Hydrosurvey }\end{array}$ & 2013 & May & $\begin{array}{l}\text { HYPACK-single } \\
\text { beam }\end{array}$ & USACE-NWK. \\
\hline $\begin{array}{l}\text { Pelican } \\
\text { Island }\end{array}$ & $\begin{array}{l}2013 \text { Pelican } \\
\text { Hydrosurvey }\end{array}$ & 2013 & $\begin{array}{l}\text { summer/ } \\
\text { fall }\end{array}$ & $\begin{array}{l}\text { HYPACK-single } \\
\text { beam }\end{array}$ & Eisenbraun Contract. \\
\hline $\begin{array}{l}\text { Tadpole } \\
\text { Island }\end{array}$ & $\begin{array}{l}2008 \text { Tadpole Island } \\
\text { Multibeam Survey }\end{array}$ & 2008 & October & multibeam survey & USACE-NWK. \\
\hline $\begin{array}{l}\text { Tadpole } \\
\text { Island }\end{array}$ & $\begin{array}{l}2012 \text { Tadpole Island } \\
\text { Control Structure }\end{array}$ & 2012 & September & $\begin{array}{l}\text { HYPACK-single } \\
\text { beam }\end{array}$ & USACE-NWK. \\
\hline $\begin{array}{l}\text { Tadpole } \\
\text { Island }\end{array}$ & $\begin{array}{l}2012 \text { Tadpole Island Feb } \\
\text { Complete Survey }\end{array}$ & 2012 & February & $\begin{array}{l}\text { HYPACK-single } \\
\text { beam+VRS }\end{array}$ & USACE-NWK. \\
\hline $\begin{array}{l}\text { Tadpole } \\
\text { Island }\end{array}$ & $\begin{array}{l}2013 \text { Tadpole Island } \\
\text { Hydrosurvey }\end{array}$ & 2013 & $\begin{array}{l}\text { summer/ } \\
\text { fall }\end{array}$ & $\begin{array}{l}\text { HYPACK-single } \\
\text { beam }\end{array}$ & Eisenbraun Contract. \\
\hline Worthwine & $\begin{array}{l}2010 \text { Flood Worthwine } \\
\text { Hydrosurvey }\end{array}$ & 2010 & summer & $\begin{array}{l}\text { HYPACK-single } \\
\text { beam }\end{array}$ & USACE-NWK. \\
\hline Worthwine & $\begin{array}{l}2011 \text { Flood Worthwine } \\
\text { Hydrosurvey }\end{array}$ & 2011 & August & $\begin{array}{l}\text { HYPACK-single } \\
\text { beam }\end{array}$ & USACE-NWK. \\
\hline Worthwine & 2012 Worthwine Survey & 2012 & February & $\begin{array}{l}\text { HYPACK-single } \\
\text { beam+VRS }\end{array}$ & USACE-NWK. \\
\hline Worthwine & $\begin{array}{c}2013 \text { Worthwine } \\
\text { Hydrosurvey }\end{array}$ & 2013 & $\begin{array}{l}\text { summer/ } \\
\text { fall }\end{array}$ & $\begin{array}{l}\text { HYPACK-single } \\
\text { beam }\end{array}$ & Eisenbraun Contract. \\
\hline
\end{tabular}


Table 6. List of datasets for two-dimensional modeling surveys that have been conducted as part of the Habitat Assessment and Monitoring Program in the Kansas City District Missouri River

[ADCP refers to acoustic Doppler current profiler. USGS refers to the U.S. Geological Survey. USACE-NWK refers to the U.S. Army Corps of Engineers, Kansas City District. Source of data is T. Gemeinhardt, U.S. Army Corps of Engineers, written commun., 2014]

\begin{tabular}{|c|c|c|c|c|c|}
\hline Location & Dataset name & Year & Season/Month/Date & Survey type & Agency/Contractor \\
\hline Chamois Bend & Chamois ADCP & 2002 & June 10-12 & $\begin{array}{l}\text { Rio Grande } \\
\text { ADCP }\end{array}$ & USGS. \\
\hline Chamois Bend & Chamois hydrosurvey & 2002 & June $10-12$ & $\begin{array}{l}\text { HYPACK-single } \\
\text { beam }\end{array}$ & USGS. \\
\hline Jameson Bend & $\begin{array}{l}\text { Jameson Bend } \\
\text { hydrosurvey }\end{array}$ & - & - & $\begin{array}{l}\text { HYPACK-single } \\
\text { beam }\end{array}$ & USACE-NWK. \\
\hline Marion Bend & $\begin{array}{l}\text { Marion Bottoms } \\
\text { ADCP }\end{array}$ & 2005 & July & $\begin{array}{l}\text { Rio Grande } \\
\text { ADCP }\end{array}$ & USACE-NWK. \\
\hline Marion Bend & $\begin{array}{l}\text { Marion Bottoms } \\
\text { hydrosurvey }\end{array}$ & 2005 & July & $\begin{array}{l}\text { HYPACK-single } \\
\text { beam }\end{array}$ & USACE-NWK. \\
\hline Rocheport Bend & $\begin{array}{l}\text { Rocheport Bend } \\
\text { ADCP }\end{array}$ & 2005 & Aug. 23 & $\begin{array}{l}\text { Rio Grande } \\
\text { ADCP }\end{array}$ & USGS. \\
\hline Rocheport Bend & $\begin{array}{l}\text { Rocheport_Bend_data } \\
\text { hydrosurvey }\end{array}$ & 2005 & Aug. 17-19 & $\begin{array}{l}\text { HYPACK-single } \\
\text { beam }\end{array}$ & USACE-NWK. \\
\hline $\begin{array}{l}\text { Slaughterhouse } \\
\text { Bend }\end{array}$ & $\begin{array}{l}\text { Slaughterhouse Bend } \\
\text { hydrosurvey }\end{array}$ & 2006 & - & $\begin{array}{l}\text { HYPACK-single } \\
\text { beam }\end{array}$ & USACE-NWK. \\
\hline $\begin{array}{l}\text { Washington } \\
\text { Bend }\end{array}$ & $\begin{array}{l}\text { Washington Bend } \\
\text { hydrosurvey }\end{array}$ & 2006 & - & $\begin{array}{l}\text { HYPACK-single } \\
\text { beam }\end{array}$ & USACE-NWK. \\
\hline Wilhoite Bend & $\begin{array}{l}\text { Wilhoite Bend } \\
\text { hydrosurvey }\end{array}$ & 2006 & - & $\begin{array}{c}\text { HYPACK-single } \\
\text { beam }\end{array}$ & USACE-NWK. \\
\hline Wilhoite Bend & $\begin{array}{l}\text { Wilhoite Bend } \\
\text { Multibeam survey }\end{array}$ & 2006 & - & multibeam & USACE-NWK. \\
\hline
\end{tabular}

\section{Evaluation and Contribution to Effects Analysis}

The assessment by Schapaugh and others (2010) documented that HAMP data from the BACI design are not sufficient to detect biological differences between control and restoration sites. Many reasons for the lack of detected differences were proposed, including the possibility that SWH construction has had no influence on the ecosystem. This conclusion seems unlikely because of the evident changes in physical habitat at many restoration sites; however, as of this report (2015), no effort to assess statistical differences in physical habitat between control and affected sites have been documented, and there have not been any published integrations of the biological and physical BACI datasets within HAMP. Lack of assessment of physical-habitat differences has limited the ability to assess types of physical change, magnitudes, and rates, and has also limited the ability to infer cause and effect between physical and biological attributes.

Nonetheless, some process-oriented HAMP studies have provided useful physical context for understanding shallow-water ecological processes (Dzialowski and others, 2012; Morris and others, 2013; Gosch and others, 2014; Gemeinhardt and others, 2015; Gosch and others, 2015). The previous assessment of HAMP data evaluated the linkage from management action to biotic response (Schapaugh and others, 2010), but did not evaluate the subsidiary links from management to habitat quantity and quality and from habitat to biotic response. This omission presents an opportunity for the EA to evaluate these linkages for possible new understanding. Synthesis of HAMP biological and physical data with CSRP data (described in the section, "Comprehensive Sturgeon Research Project”) may also provide new insights. 
Table 7. List of datasets for physical habitat surveys that have been conducted as part of the Habitat Assessment and Monitoring Program in the Omaha district Missouri River

[B, single beam bathymetry; M, multibeam; S, sediment samples, A, acoustic Doppler current profiler (ADCP) data. Source of data is T. Gemeinhardt, U.S. Army Corps of Engineers, written commun., 2014]

\begin{tabular}{|c|c|c|c|c|c|c|c|c|c|c|c|c|}
\hline \multirow[b]{2}{*}{ Location } & \multirow[b]{2}{*}{ Type } & \multicolumn{2}{|c|}{ River mile } & \multirow[b]{2}{*}{2005} & \multicolumn{8}{|c|}{ HAMP Survey Data Year } \\
\hline & & DS & US & & 2006 & 2007 & 2008 & 2009 & 2010 & 2011 & 2012 & 2013 \\
\hline Upper Glovers Point Bend & River Bend (channel) & 712 & 714.3 & - & B & BAS & BMS & BMS & \multirow{23}{*}{ 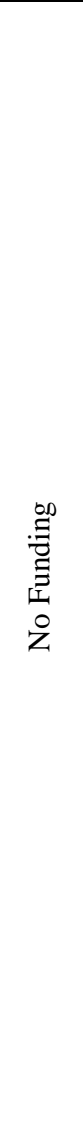 } & - & - & BMA \\
\hline Lower Decatur Bend & River Bend (channel) & 686 & 687.4 & - & BA & BS & $\mathrm{BM}$ & - & & - & - & BMA \\
\hline Upper Louisville Bend & River Bend (channel) & 683.4 & 686 & - & BA & BAS & $\mathrm{BM}$ & - & & - & - & BMA \\
\hline Upper Little Sioux Bend & River Bend (channel) & 674.8 & 676.3 & - & B & BAS & $\mathrm{BM}$ & - & & - & - & BMA \\
\hline Lower Little Sioux Bend & River Bend (channel) & 670.5 & 672.8 & B & $\mathrm{BA}$ & BAS & $\mathrm{BM}$ & $\mathrm{BM}$ & & - & - & BMA \\
\hline Peterson Cut-off & River Bend (channel) & 657.8 & 659.2 & B & B & BAS & $\mathrm{BM}$ & $\mathrm{BM}$ & & - & - & BA \\
\hline Tysons Bend & River Bend (channel) & 651.6 & 655 & B & B & BAS & B & - & & - & - & BA \\
\hline Desoto Cut-off & River Bend (channel) & 641.8 & 644.8 & B & BA & BS & $\mathrm{BM}$ & $\mathrm{BM}$ & & - & - & BA \\
\hline Lower Calhoun Bend & River Bend (channel) & 637.3 & 638.5 & - & BA & BA & B & B & & - & - & BA \\
\hline Boyer Bend & River Bend (channel) & 634.1 & 636 & BA & B & BA & BA & B & & - & - & BA \\
\hline Tobacco Bend & River Bend (channel) & 586.3 & 589.4 & - & BMAS & BA & MA & - & & - & - & BMA \\
\hline Pin Hook & River Bend (channel) & 576.8 & 579.2 & - & BMAS & BA & MA & - & & - & - & BMA \\
\hline Van Horns & River Bend (channel) & 574.8 & 576.8 & - & BMAS & BA & MA & - & & - & - & - \\
\hline Upper Civil Bend & River Bend (channel) & 572.8 & 574.8 & - & BMAS & BA & MA & - & & - & - & BMA \\
\hline Lower Civil Bend & River Bend (channel) & 571.5 & 572.8 & - & BMAS & BA & MA & - & & - & - & BMA \\
\hline Lower Copeland & River Bend (channel) & 562.9 & 565.1 & - & BMAS & BAS & MA & - & & - & - & BMA \\
\hline Nebraska & River Bend (channel) & 560.4 & 562.9 & - & BMAS & BA & MA & MA & & - & - & BMA \\
\hline Otoe & River Bend (channel) & 555.5 & 556.7 & - & BAS & BS & MA & MA & & - & - & BMA \\
\hline Upper Hamburg Bend & River Bend (channel) & 552.9 & 555.9 & - & BAS & BAS & MA & - & & - & - & BMA \\
\hline Glovers Point Chute & Chute (off-channel) & 711.2 & 713.4 & - & - & - & - & - & & BA & - & - \\
\hline Middle Decatur Chute & Chute (off-channel) & 687.4 & 688.2 & - & - & - & - & - & & BA & - & B \\
\hline Lower Decatur Chute & Chute (off-channel) & 684.9 & 687.3 & - & - & - & - & - & & B & - & - \\
\hline Fawn Island Chute & Chute (off-channel) & 673.3 & 674.1 & - & - & - & - & - & & BA & B & B \\
\hline
\end{tabular}


Table 7. List of datasets for physical habitat surveys that have been conducted as part of the Habitat Assessment and Monitoring Program in the Omaha district Missouri River-Continued

\begin{tabular}{|c|c|c|c|c|c|c|c|c|c|c|c|c|}
\hline \multirow[b]{2}{*}{ Location } & \multirow[b]{2}{*}{ Type } & \multicolumn{2}{|c|}{ River mile } & \multirow[b]{2}{*}{2005} & \multicolumn{8}{|c|}{ HAMP Survey Data Year } \\
\hline & & DS & US & & 2006 & 2007 & 2008 & 2009 & 2010 & 2011 & 2012 & 2013 \\
\hline Sandy Point Chute & Chute (off-channel) & 655 & 657.8 & - & - & - & - & - & \multirow{23}{*}{ 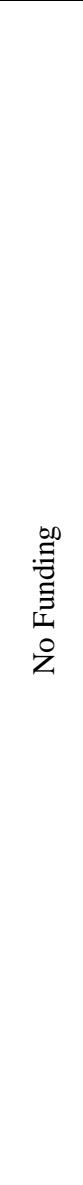 } & - & - & $\mathrm{BA}$ \\
\hline California Bend, IA, Chute & Chute (off-channel) & 649.5 & 650.1 & - & - & - & - & - & & BA & $\mathrm{B}$ & B \\
\hline California Bend, NE, Chute & Chute (off-channel) & 648.5 & 650.1 & - & - & - & - & - & & BA & - & - \\
\hline Lower Calhoun Chute & Chute (off-channel) & 637.1 & 637.6 & - & - & - & - & - & & B & - & - \\
\hline Boyer Chute & Chute (off-channel) & 633.7 & 637.8 & - & - & - & - & - & & BA & BA & BA \\
\hline Council Bend Chute & Chute (off-channel) & 616.8 & 617.8 & - & - & - & - & - & & BA & BA & BA \\
\hline Plattsmouth Chute & Chute (off-channel) & 592.1 & 594.5 & - & - & - & - & - & & BA & BA & BA \\
\hline Tobacco Island Chute & Chute (off-channel) & 586.3 & 588.4 & - & - & - & - & - & & BA & BA & BA \\
\hline Upper Hamburg Chute & Chute (off-channel) & 552.2 & 555.9 & - & - & - & - & - & & BA & BA & BA \\
\hline Lower Hamburg Chute & Chute (off-channel) & 550.6 & 553.4 & - & - & - & - & - & & BA & BA & BA \\
\hline Kansas Bend Chute & Chute (off-channel) & 544.5 & 546.4 & - & - & - & - & - & & BA & BA & BA \\
\hline Nishnabotna Chute & Chute (off-channel) & 542.4 & 543.3 & - & - & - & - & - & & BA & BA & $\mathrm{B}$ \\
\hline Deroin Bend Chute & Chute (off-channel) & 516.4 & 520.5 & - & - & - & - & - & & BA & BA & BA \\
\hline Rush Bottoms Chute & Chute (off-channel) & 499 & 502 & - & - & - & - & - & & BA & BA & $\mathrm{B}$ \\
\hline Ponca State Park Backwater & Backwater & 753 & - & - & - & - & - & - & & $\mathrm{B}$ & B & $\mathrm{B}$ \\
\hline Glovers Pt Backwater & Backwater & 711.5 & - & - & - & - & - & - & & $\mathrm{B}$ & $\mathrm{B}$ & $\mathrm{B}$ \\
\hline Hole In the Rock Backwater & Backwater & 706 & - & - & - & - & - & - & & $\mathrm{B}$ & $\mathrm{B}$ & $\mathrm{B}$ \\
\hline Soldier Bend Backwater & Backwater & 660.4 & - & - & - & - & - & - & & B & B & B \\
\hline Tyson Backwater & Backwater & 653.2 & - & - & - & - & - & - & & B & $\mathrm{B}$ & B \\
\hline California Bend (IA) Backwater & Backwater & 649.5 & - & - & - & - & - & - & & $\mathrm{B}$ & $\mathrm{B}$ & $\mathrm{B}$ \\
\hline Boyer Backwater & Backwater & 634.2 & - & - & - & - & - & - & & $\mathrm{B}$ & $\mathrm{B}$ & $\mathrm{B}$ \\
\hline Plattsmouth Backwater & Backwater & 592.3 & - & - & - & - & - & - & & $\mathrm{B}$ & $\mathrm{B}$ & $\mathrm{B}$ \\
\hline Langdon Bend Backwater & Backwater & 529 & - & - & - & - & - & - & & $\mathrm{B}$ & $\mathrm{B}$ & $\mathrm{B}$ \\
\hline
\end{tabular}




\section{Comprehensive Sturgeon Research Project}

The Comprehensive Sturgeon Research Project (CSRP) is an interagency collaboration of the USGS, NGPC, MtFWP, USFWS, and the USACE Missouri River Recovery-Integrated Science Program. The goal of CSRP is to improve the fundamental understanding of the reproductive ecology of the pallid sturgeon to better inform management decisions about the Missouri River and its species. Specific objectives pursued 2005-14 are summarized below:

1. Determine movement, habitat use, and reproductive behavior of pallid sturgeon;

2. Understand reproductive physiology of pallid sturgeon and its relations to environmental conditions;

3. Determine origin, transport, and fate of drifting pallid sturgeon larvae and evaluate bottlenecks for recruitment of early-life stages;

4. Quantify availability and dynamics of aquatic habitats needed by pallid sturgeon for all life stages; and

5. Manage databases, integrate understanding, and publish relevant information into the public domain.

CSRP research is intended to provide managers with improved understanding of linkages among flow regime, reengineered channel morphology, and pallid sturgeon movement, habitat use, reproduction, and survival.

CSRP direction has been guided by results of sturgeon research workshops convened in 2004 (Quist and others, 2004) and 2007 (Bergman and others, 2008), by hypotheses that emerged about the role of a naturalized-flow regime in pallid sturgeon reproduction during a series of workshops in 2005 (Jacobson and Galat, 2008), by feedback from an independent science review (Sustainable Ecosystems Institute, 2008), and by a recent independent science panel review of spring pulses (Doyle and others, 2011). Research objectives have emphasized science information gaps related to priority management issues, including understanding of the role of pulsed flow releases from Gavins Point Dam and Fort Peck Dam (fig. 1), design of passage structures at Intake Dam, and understanding of the functions of constructed SWH in sturgeon spawning and recruitment.

The CSRP approach integrates field-based experiments and controlled laboratory studies. The field study plan is designed to explore the roles of flow regime, channel configuration, and environmental cues in sturgeon reproduction and recruitment. The project uses an upstream-downstream experimental design to compare sturgeon reproductive behavior among four hydrologic regimes in four sections of the Missouri River (fig. 6): (1) the Upper Missouri River downstream from Fort Peck Dam, including the downstream reaches of the Milk River; (2) the Lower Yellowstone River; (3) an upstream section of the Lower Missouri River with a highly altered flow regime; and (4) a downstream section of the Lower Missouri River that maintains much of its preregulation flow variability (Galat and Lipkin, 2000). Variations in channel morphology from near natural conditions in the Upper Missouri and Yellowstone Rivers to channelized and variably restored in the Lower Missouri River allow for evaluation of how channel form relates to spawning, dispersal, and rearing. 


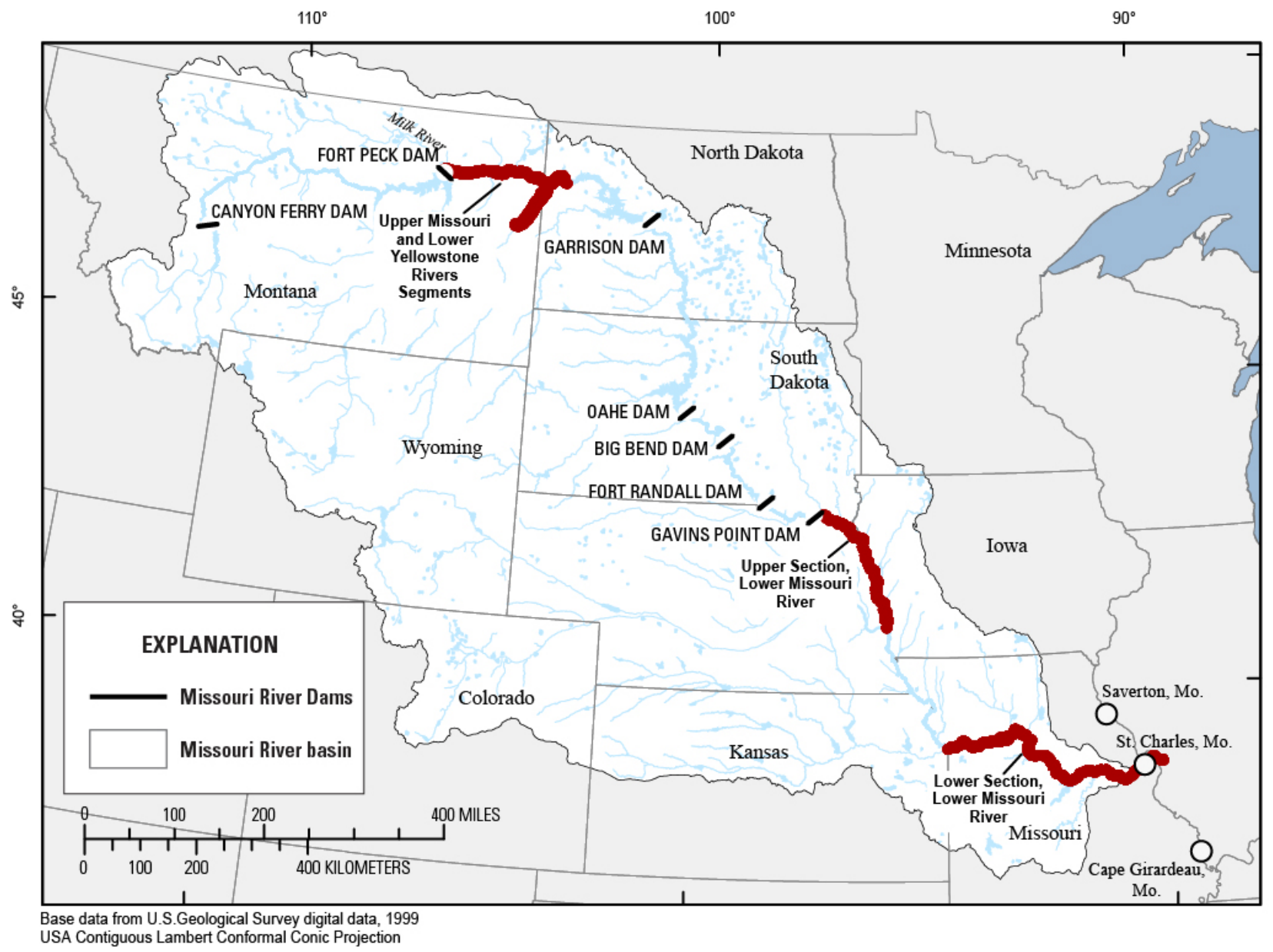

Figure 6. Map showing the four segments researched by the Comprehensive Sturgeon Research Project.

CSRP has emphasized understanding of reproductive ecology of adult and early-life-stage sturgeon. For understanding reproductive behaviors of adults, the CSRP approach has been to capture shovelnose and pallid sturgeon, evaluate the reproductive status of each individual (Korschgen and others, 2007), and instrument each with a uniquely coded acoustic or acoustic- and radio-combined telemetry transmitter. Archival data-storage tags (DST) are used to record temperature and depth (as pressure) at 15 to 30 minute intervals. Telemetry has been used to locate individual sturgeon over several years to collect information on movement, habitat use, behavior, and response to environmental cues, or to habitat manipulations. Sturgeon have been tracked extensively (targeted for monthly contact) during pre- and post-spawn periods to document seasonal patterns of movement and identify potentially limiting habitats. Pallid sturgeon in reproductive condition also have been tracked intensively (targeted for contact weekly, daily, or several times daily) with increasing frequency as spawning became imminent from April through June, or until re-collection indicated that spawning was complete. Attempts have been made to recover the sturgeon immediately after spawning in order to evaluate spawning success, as well as recover the DST device and recorded data. Effective use of telemetry presented the opportunity to recapture, reassess, and re-implant individual pallid sturgeon to monitor changes in growth, condition, and reproductive status over periods of several years (DeLonay and others, 2009; DeLonay and others, 2010; DeLonay and others, 2012).

Studies of pallid sturgeon adult movement and reproductive behavior in the Upper Missouri and Yellowstone Rivers were combined into CSRP in 2011. Efforts are similar, although sturgeon tracking on the Yellowstone River relies primarily on radio transmitters and DSTs are not currently (2015) used. Tracking is seasonally limited in the Upper Missouri and Yellowstone Rivers due to water temperatures 
and winter ice cover. The period of extensive tracking is shorter and the study of intensive migration and spawning period is focused in the month of June. As ongoing efforts from the Upper Missouri and Yellowstone section were recently (2013) incorporated into CSRP, the data are not completely assimilated in the database at the time of this report (October 2015).

CSRP has an extensive, coordinated, and detailed effort to quantify habitat use and availability (Reuter and others, 2008; DeLonay and others, 2009; Elliott and others, 2009; Jacobson and others, 2009; Reuter and others, 2009; Bonnot and others, 2011; DeLonay and others, 2012; McElroy and others, 2012; Erwin and Jacobson, 2014; DeLonay and others, 2015). Habitat assessments from 2010-15 have focused on migration of reproductive adults, spawning patch selection, and drift and fate of dispersing free embryos.

Since 2009, efforts to verify spawning have focused on capturing newly hatched and drifting free embryos at locations pallid sturgeon are believed to have spawned in the Lower Missouri River (DeLonay and others, 2012). Verification sampling is conducted immediately downstream of sites where telemetered sturgeon are believed to have completed spawning based upon habitat use, movement or behavior. Systematic sampling for free embryo sturgeon and paddlefish was initiated in 2012 and is conducted along transects perpendicular to the flow at intervals throughout the spawning and dispersal periods. Systematic sampling was performed in 2012 in the Lower Missouri River near St. Charles, Mo. from mid-April into mid-October to detect timing and extent of spawning by sturgeon and paddlefish, and species composition and abundance of Acipenseriformes free embryos drifting in the Lower Missouri River. Systematic sampling was moved upstream in 2013 to mitigate safety concerns associated with sampling the thalweg (where most Acipenseriformes free embryos drift), in a particularly deep, swift, and barge-congested part of the Missouri River. The upstream sample section is also thought to be more likely affected by management actions. Systematic sampling in 2013 and 2014 was performed at two sites from late-April through late-July, one site in the main stem Missouri River upstream of the confluence with the Platte River near RM 599.5 (fig. 1) and the second in the Platte River less than 1 mile from its confluence with the Missouri River. Paired 0.5-m diameter conical ichthyoplankton nets (750 $\mu \mathrm{m}$ mesh) equipped with General Oceanic ${ }^{\odot}$ velocity meters and attached to 100-lb (45.4 kg) Columbus-style sounding weights were deployed from an anchored 8-meter research vessel outfitted with paired booms and winches (port and starboard). Ichthyoplankton samples were sorted on board the research vessel shortly after collection. All Acipenseriformes free embryos identified as either sturgeon (Scaphirhynchus spp.) or Polydon spathula (paddlefish) were preserved in 70 percent ethanol for identification to genus in the laboratory. All specimens identified as potential Scaphirhynchus sturgeon free embryos were sent for species determination using genetic analyses at Southern Illinois University Carbondale.

Spawning verification, followed by systematic free embryo sampling in the Upper Missouri and Yellowstone Rivers, were added to CSRP in 2011 through 2014. As these efforts were recently added to CSRP, the data have not been fully assimilated into Sturgeon Information Management System (SIMS) at present. Methods employed are similar to those used in the Lower Missouri River, although heavy weights are not required and samples are only collected near the bottom of the channel.

CSRP datasets include categories related to locations, movements, physiological indicators, and genetics of individual monitored fish, as well as ancillary data related to water temperature, water quality, habitat availability, and habitat use. The bulk of the data reside in two datasets housed at the USGS, Columbia Environmental Research Center, Columbia, Mo.: The SIMS and the Missouri River Hydroacoustic Habitat Dynamics System (MRHHDS). Access to these datasets can be arranged through requests to the chief of the River Studies Branch, USGS-CERC, Columbia, Mo. 
Sturgeon Information Management System

The ongoing CSRP research generates a variety of data:

- Sturgeon capture efforts,

- Individual morphometric measures,

- Physiological measurements of spawning readiness,

- Device implantation records,

- Reproductive condition assessments,

- Telemetry observations,

- Free-embryo sampling efforts, and

- Environmental variables.

The CSRP SIMS is a central platform to collect, maintain, organize, integrate, and explore the diverse data collected by multiple agency partners. The CSRP SIMS platform accommodates disparate data types by using a suite of software to accommodate various data formats and the demand for near real-time updates (fig. 7). The SIMS mobile mapping application was developed to capture and incorporate data in SIMS using ArcPad® (Esri, Redlands, Calif.). SIMS has recently been expanded and utilized in the Upper Missouri and Yellowstone Rivers. The mobile mapping component allows researchers to collect real-time geospatial telemetry data, quality check the data, and upload the data to a relational database. Data tables for sampling efforts, telemetry device implantations, individual fish metrics, physiology, environmental variables, and others have been integrated so that the data are available and searchable (table 8). A functionally-driven SIMS user interface has been developed using Microsoft Access ${ }^{\circledR}$ (Microsoft Inc., Seattle, Wash.) to allow users to view data quickly, as well as to access near real-time reports that present synthesized information from both tabular and geospatial data (DeLonay and others, 2010).

The SIMS relational database consists of over 10.3 million data records in 11 essential tables and three geospatial datasets to support CSRP research (table 8). Eight tables and three geospatial datasets are utilized to quantify spawning movement, habitat use, and behavior of pallid sturgeon and shovelnose sturgeon in the Lower Missouri River. Since the CSRP was initiated, 175 pallid sturgeon and 376 shovelnose sturgeon have been implanted with telemetry tags or telemetry tags in combination with DST devices that record fish depths and ambient temperature in the Lower Missouri River. Of these, 172 (98.3 percent) pallid sturgeon and 352 (94.6 percent) shovelnose sturgeon were located at least once after release (tables 9 and 10). More than 80 pallid sturgeon have been in the CSRP study for multiple years and have had multiple telemetry and DST devices during that time. From pallid sturgeon implanted with DST devices, more than 3.3 million depth and temperature records have been archived. To provide a better environmental context for pallid and shovelnose sturgeon movement and habitat use, approximately 6.9 million temperature records have been collected from a network of 28 CSRP temperature loggers in the Lower Missouri River and its tributaries (table 8) since 2002.

SIMS includes recent, comparable information for pallid sturgeon in the Upper Missouri and Yellowstone Rivers. Since 2011, 1,374 telemetry locations have been recorded from 95 unique telemetry tags implanted in pallid sturgeon (table 11). Similarity of data structures across all CSRP study sections facilitates comparative assessments throughout a substantial portion of the species' range. 


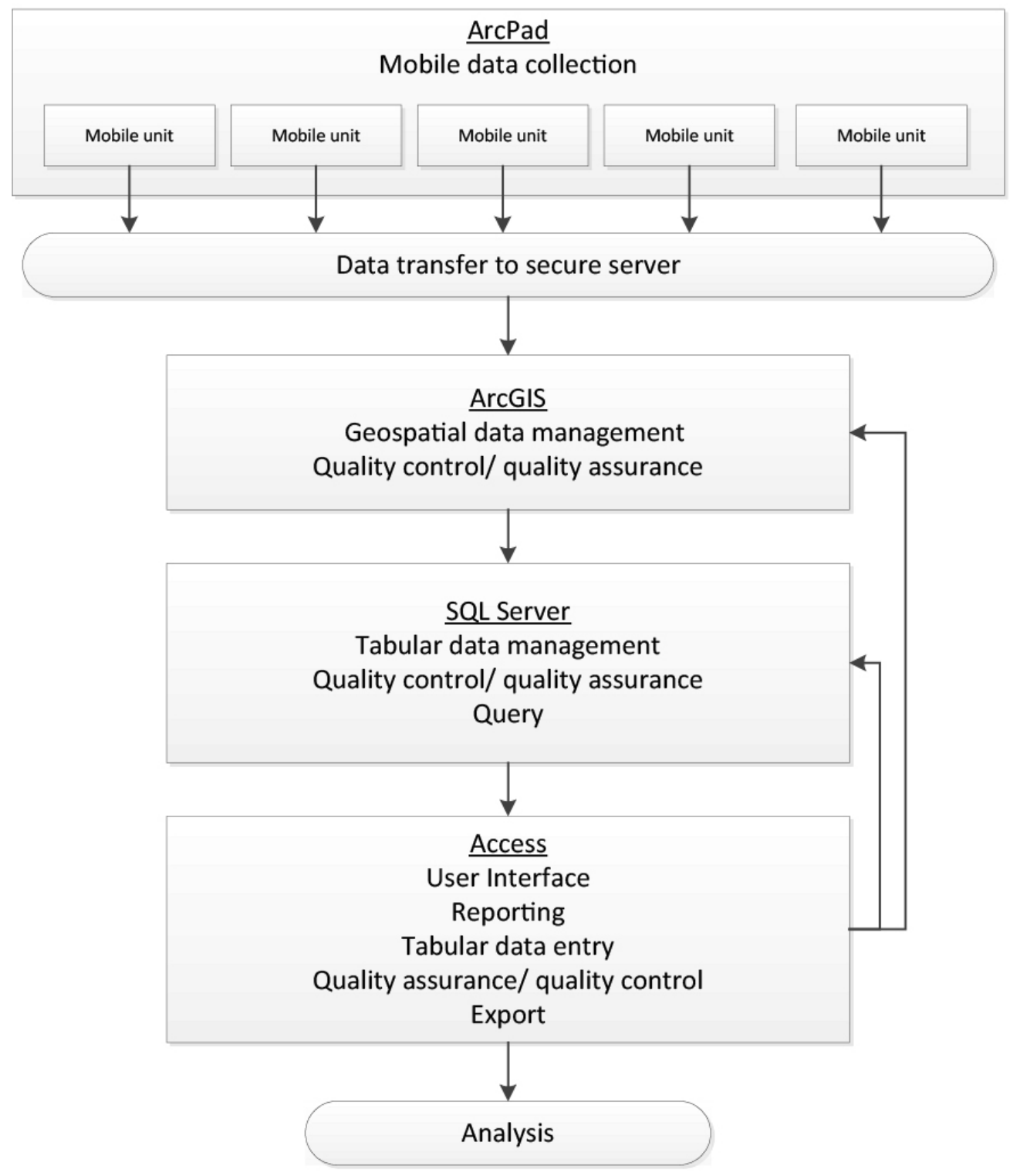

Figure 7. Diagram showing overview of Sturgeon Information Management System used to collect, manage, integrate, and explore data for the Comprehensive Sturgeon Research Project.

Three primary tables are used to support the spawning verification and systematic sampling efforts for free embryos (table 8). These data include a total of 339 spawning verification gear deployments to sample for sturgeon eggs and free embryos at the probable spawning sites of telemetered female pallid sturgeon from 2009 through 2014, during which 12 sturgeon free embryos were collected. Systematic sampling efforts during 2012 through 2014 resulted in a total of 3,196 gear deployments at 2 locations, collecting a total of 1,093 sturgeon and 807 paddlefish free embryos. 
Table 8. Description of primary datasets collected and maintained by the Sturgeon Information Management System for the Comprehensive Sturgeon Research Project

[Geospatial datasets are maintained in native ESRI shapefile format. CSRP refers to the Comprehensive Sturgeon Research Project]

\begin{tabular}{|c|c|c|c|}
\hline Table & Description & $\begin{array}{l}\text { Number } \\
\text { of records }\end{array}$ & Time period \\
\hline \multicolumn{4}{|c|}{ Geospatial datasets } \\
\hline Sturgeon & $\begin{array}{l}\text { Pallid and shovelnose sturgeon locations recorded for the CSRP research, } \\
\text { including telemetry locations, initial release locations, and recapture } \\
\text { locations in the Lower Missouri River. }\end{array}$ & 17,286 & $\begin{array}{c}\text { 2005- } \\
\text { present. }\end{array}$ \\
\hline SearchEfforts & $\begin{array}{l}\text { Details of tracking vessel search efforts recorded for the CSRP research in } \\
\text { the Lower Missouri River. }\end{array}$ & - & $\begin{array}{c}2005- \\
\text { present. }\end{array}$ \\
\hline Sturgeon_UB & $\begin{array}{l}\text { Pallid telemetry locations recorded for the CSRP research in the Upper } \\
\text { Missouri and Yellowstone Rivers. }\end{array}$ & 1,374 & $\begin{array}{c}2011- \\
\text { present. }\end{array}$ \\
\hline
\end{tabular}

Tabular datasets

\begin{tabular}{|c|c|c|c|}
\hline TBL_DST & $\begin{array}{l}\text { Stores temperature and depth (recorded as pressure) data recorded at 15-30 } \\
\text { minute interval by archival data storage tags (DST) retrieved from } \\
\text { individual pallid sturgeon. }\end{array}$ & $3,473,679$ & $\begin{array}{c}2006- \\
\text { present. }\end{array}$ \\
\hline TBL_Gear & $\begin{array}{l}\text { Details of each gear deployed in order to capture or recapture sturgeon for } \\
\text { CSRP research, including gear type, location, date, time, habitat type, } \\
\text { depth, substrate, and water quality descriptors. }\end{array}$ & 4,385 & $\begin{array}{l}2005- \\
\text { present. }\end{array}$ \\
\hline TBL_Genetics & $\begin{array}{l}\text { Details of each genetic sample taken, including vial number, PIT tag, } \\
\text { capture date, date sent, results from the geneticist, and date results were } \\
\text { received. }\end{array}$ & 216 & $\begin{array}{l}2007- \\
\text { present. }\end{array}$ \\
\hline TBL_LarvalGear & $\begin{array}{l}\text { Details of each gear deployed in order to sample for sturgeon eggs or } \\
\text { larvae for CSRP research, including location, date, temperature, and water } \\
\text { depth. }\end{array}$ & 2,382 & $\begin{array}{l}\text { 2009- } \\
\text { present. }\end{array}$ \\
\hline TBL_LarvalSamples & $\begin{array}{l}\text { Details of each larval sampling net, including sample duration, water } \\
\text { volume sampled, and relative depth (bottom or mid-column). }\end{array}$ & 4,705 & $\begin{array}{c}2009- \\
\text { present. }\end{array}$ \\
\hline TBL_LarvalResults & $\begin{array}{l}\text { Details of larval specimen collected for the CSRP, including species } \\
\text { determination, length, and age estimation. }\end{array}$ & 1,149 & $\begin{array}{l}2009- \\
\text { present. }\end{array}$ \\
\hline TBL_PallidData & $\begin{array}{l}\text { Details of every field identified pallid sturgeon captured for the CSRP, } \\
\text { including identifiers or marks, morphometrics and fate of each individual } \\
\text { fish, capture date, capture location, habitat, and water quality. }\end{array}$ & 949 & $\begin{array}{l}2005- \\
\text { present. }\end{array}$ \\
\hline TBL_Physiology & $\begin{array}{l}\text { Details of hormone values estimated form shovelnose and pallid sturgeon } \\
\text { blood or eggs. }\end{array}$ & 3,165 & 2001-2013. \\
\hline TBL_Procedure & $\begin{array}{l}\text { Details of each telemetry device implantation procedure including } \\
\text { telemetry tag identifiers (frequency, code, and serial number), sex, } \\
\text { reproductive condition, date, location, and procedure length. }\end{array}$ & 921 & $\begin{array}{l}2005- \\
\text { present. }\end{array}$ \\
\hline TBL_TransmitterTags & $\begin{array}{l}\text { Details of telemetry transmitters for CSRP research, including } \\
\text { manufacturer, model number, serial number, frequency, code, and } \\
\text { expected battery life. }\end{array}$ & 1,042 & $\begin{array}{l}2005- \\
\text { present. }\end{array}$ \\
\hline TBL_Temperature & $\begin{array}{l}\text { Temperature records at } 16 \text { locations on the Missouri River and } 12 \\
\text { tributaries (including the Big Sioux, Chariton, Gasconade, Grand, James, } \\
\text { Kansas, Lamine, Little Sioux, Nishnabotna, Nodaway, Osage, and } \\
\text { Vermillion Rivers). }\end{array}$ & $6,893,293$ & $\begin{array}{l}2002- \\
\text { present. }\end{array}$ \\
\hline
\end{tabular}


Table 9. Summary of the number of pallid sturgeon implanted with telemetry devices, number tracked, locations recorded, reimplanted with telemetry devices, and reproductive evaluations, per year in the Lower Missouri River; 2005-2013 [DST refers to data storage tags]

\begin{tabular}{|c|c|c|c|c|c|}
\hline Year & $\begin{array}{l}\text { Number } \\
\text { implanted }\end{array}$ & $\begin{array}{l}\text { Number } \\
\text { tracked }\end{array}$ & $\begin{array}{l}\text { Number of } \\
\text { telemetry } \\
\text { locations }\end{array}$ & $\begin{array}{l}\text { Number } \\
\text { reimplanted }\end{array}$ & $\begin{array}{l}\text { Number } \\
\text { DST } \\
\text { devices } \\
\text { retrieved }\end{array}$ \\
\hline 2005 & 10 & 9 & 56 & 0 & 0 \\
\hline 2006 & 16 & 18 & 310 & 0 & 0 \\
\hline 2007 & 20 & 35 & 981 & 4 & 1 \\
\hline 2008 & 55 & 82 & 2547 & 21 & 0 \\
\hline 2009 & 14 & 74 & 1210 & 14 & 12 \\
\hline 2010 & 32 & 75 & 2013 & 11 & 16 \\
\hline 2011 & 20 & 78 & 1280 & 12 & 17 \\
\hline 2012 & 2 & 67 & 1522 & 37 & 34 \\
\hline 2013 & 3 & 55 & 1747 & 12 & 16 \\
\hline
\end{tabular}

Table 10. Summary of the number of shovelnose sturgeon implanted with telemetry devices, tracked, intensively tracked, telemetry locations recorded, and number recaptured per year in the Lower Missouri River; 2005-2008.

\begin{tabular}{ccccc}
\hline Year & $\begin{array}{l}\text { Number } \\
\text { implanted }\end{array}$ & $\begin{array}{l}\text { Number } \\
\text { extensively } \\
\text { tracked }\end{array}$ & $\begin{array}{l}\text { Number of } \\
\text { telemetry } \\
\text { locations }\end{array}$ & $\begin{array}{l}\text { Number } \\
\text { recaptured }\end{array}$ \\
\hline 2005 & 100 & 100 & 702 & 19 \\
2006 & 100 & 101 & 825 & 23 \\
2007 & 176 & 197 & 4011 & 114 \\
2008 & -- & 25 & 82 & 5 \\
\hline
\end{tabular}

Table 11. Summary of the number of pallid sturgeon telemetry locations recorded, and number of unique telemetry codes recorded per year in the Upper Missouri River; 2011-2013.

\begin{tabular}{ccc} 
Year & Number of telemetry locations & Number unique telemetry codes \\
\hline 2011 & 289 & 39 \\
2012 & 607 & 56 \\
2013 & 478 & 67 \\
\hline
\end{tabular}




\section{Missouri River Hydroacoustic Habitat Dynamics System (MRHHDS)}

The CSRP has collected and analyzed hydroacoustic habitat data on the Lower Missouri River and its tributaries in South Dakota, Nebraska, Iowa, Kansas, and Missouri as well as on the Upper Missouri and Yellowstone Rivers in Montana and North Dakota. The objective of these studies has been to quantify habitat conditions used, and not used, by pallid sturgeon. Data collection efforts and equipment have varied by project over the period of collection and include single-beam and multibeam bathymetry, ADCP velocity measurements, substrate classifications, and side-scan sonar imagery; acoustic data were georeferenced with real-time kinematic global positioning system (RTK GPS) ground-survey data (table 12). Additional hydroacoustic data have been collected as part of specific research projects, but have not been compiled as map products (table 13).

Data are archived and housed at CERC in Columbia, Mo., and are organized in a file structure (MRHHDS) sorted both geographically and temporally by major river segment and survey date within river segments. Single-beam, multibeam, and ADCP data were collected using standardized hydroacoustic collection methods (Elliott and others, 2004; Gaeuman and Jacobson, 2005; Reuter and others, 2008; DeLonay and others, 2012). Map reaches vary from 0.1 to 8 river miles, total approximately 330 river miles (with some overlap), and are distributed over a wide geographic range on the Lower Missouri River and Yellowstone River (table 14).

CSRP-related hydroacoustic habitat dynamics data fall into eight general categories:

1. Targeted sturgeon habitat investigations: 2003-14. Datasets include various targeted mappings of pallid and shovelnose sturgeon habitats from telemetry data. Habitats mapped include suspected spawning locations, migratory locations and pathways, frequently used habitats, overwintering habitats, and habitats used by sturgeon aggregations.

2. Randomized shovelnose sturgeon habitat use: 2005-07. Reaches were generally comprised of a bend-crossover-bend sequence centered on a randomly selected telemetered shovelnose sturgeon location. A few pallid sturgeon locations are included with this dataset. All maps and detailed methods are published in Reuter and others (2008). Interpretative analyses of these datasets have also been published (Reuter and others, 2009; Bonnot and others, 2011).

3. Pallid sturgeon spawning sites: 2008-14. Pallid sturgeon spawning sites have been mapped in conjunction with telemetry and prespawing and postspawning assessments on the Missouri River and Yellowstone River. Some sites mapped on the Yellowstone River include sites where male sturgeon have aggregated during the spring spawning period. Lower Missouri River spawning sites were mapped using a multibeam echosounder and an ADCP.

4. Pallid sturgeon migration pathways: 2010-13. Pallid sturgeon habitats were mapped to assess migratory habitats used by reproductive pallid Sturgeon on the Lower Missouri River, the Upper Missouri River, and the Yellowstone River. Data were collected in four reciprocal ADCP transects perpendicular to current at fish telemetry locations (McElroy and others, 2012).

5. Larval pallid and shovelnose sturgeon sampling sites: 2012-14. Habitat mapping at larval sampling sites includes a patch of ADCP transects around the larval sampling sites upstream from the confluence of the Missouri River and Mississippi River near St. 
Table 12. Map product types and areas mapped by year and data category for Missouri River and tributary reaches

\begin{tabular}{|c|c|c|c|c|c|c|c|c|}
\hline \multirow[b]{2}{*}{ Data category } & \multirow[b]{2}{*}{ Year } & \multicolumn{5}{|c|}{ Mapped product type } & \multirow{2}{*}{$\begin{array}{c}\text { Area, in } \\
\text { square km }\end{array}$} & \multirow{2}{*}{$\begin{array}{c}\text { Approximate } \\
\text { total length } \\
\text { mapped, in } \\
\text { river miles }\end{array}$} \\
\hline & & Depth & Multibeam & Velocity & Substrate & Sidescan & & \\
\hline \multirow{9}{*}{$\begin{array}{l}\text { Targeted pallid and } \\
\text { snovelnose sturgeon } \\
\text { habitat use (not } \\
\text { randomized) }\end{array}$} & 2003 & 1 & 0 & 1 & 0 & 0 & 0.63 & 1 \\
\hline & 2004 & 3 & 0 & 3 & 0 & 0 & 1.49 & 2.72 \\
\hline & 2005 & 29 & 0 & 29 & 29 & 0 & 12.2 & 29.5 \\
\hline & 2006 & 19 & 0 & 19 & 19 & 8 & 10.67 & 23.9 \\
\hline & 2007 & 11 & 0 & 11 & 11 & 11 & 4.47 & 8.4 \\
\hline & 2009 & 8 & 6 & 7 & 0 & 0 & 1.51 & 3.6 \\
\hline & 2011 & 2 & 1 & 2 & 0 & 0 & 1.16 & 3.9 \\
\hline & 2012 & 1 & 0 & 1 & 0 & 0 & 0.67 & 1.4 \\
\hline & Total & 74 & 7 & 73 & 59 & 19 & 32.8 & 74.42 \\
\hline \multirow{4}{*}{$\begin{array}{l}\text { Randomly selected } \\
\text { sturgeon habitat } \\
\text { (primarily } \\
\text { shovelnose) (Reuter } \\
\text { and others, 2008, } \\
\text { Reuter and others, } \\
\text { 2009) } \\
\end{array}$} & 2005 & 70 & 0 & 69 & 70 & 0 & 47.98 & 104.4 \\
\hline & 2006 & 14 & 0 & 14 & 14 & 2 & 9.53 & 20.7 \\
\hline & 2007 & 20 & 0 & 20 & 20 & 0 & 10.71 & 29 \\
\hline & Total & 104 & 0 & 103 & 103 & 2 & 68.22 & 154.1 \\
\hline \multirow{3}{*}{$\begin{array}{c}\text { Pallid sturgeon } \\
\text { migratory habitat } \\
\text { (DeLonay and others, } \\
\text { 2009, DeLonay and } \\
\text { others, 2012 ; } \\
\text { McElroy and others, } \\
\text { 2012) } \\
\end{array}$} & 2010 & 2 & 2 & 2 & 0 & 0 & 0.84 & 1.3 \\
\hline & 2011 & 1 & 0 & 1 & 0 & 1 & 0.24 & 0.47 \\
\hline & Total & 3 & 2 & 3 & 0 & 1 & 1.08 & 1.77 \\
\hline \multirow{7}{*}{$\begin{array}{l}\text { Pallid sturgeon } \\
\text { spawning habitat } \\
\text { (DeLonay and others } \\
\text { 2009, DeLonay and } \\
\text { others, 2012) }\end{array}$} & 2008 & 3 & 3 & 3 & 0 & 3 & 0.64 & 1.8 \\
\hline & 2009 & 3 & 2 & 3 & 0 & 1 & 0.63 & 1.4 \\
\hline & 2010 & 2 & 2 & 2 & 0 & 1 & 0.41 & 1.2 \\
\hline & 2011 & 2 & 2 & 2 & 0 & 1 & 0.63 & 1.3 \\
\hline & 2012 & 2 & 2 & 2 & 0 & 1 & 0.58 & 1.4 \\
\hline & 2013 & 7 & 3 & 7 & 0 & 6 & 2.85 & 7.35 \\
\hline & Total & 19 & 14 & 19 & 0 & 13 & 5.74 & 14.45 \\
\hline \multirow{4}{*}{$\begin{array}{c}\text { Larval sturgeon } \\
\text { sampling habitat } \\
\text { characterization }\end{array}$} & 2011 & 1 & 1 & 1 & 0 & 0 & 0.88 & 1.3 \\
\hline & 2012 & 4 & 0 & 4 & 0 & 0 & 0.91 & 1.6 \\
\hline & 2013 & 1 & 0 & 1 & 0 & 1 & 0.16 & 0.4 \\
\hline & Total & 6 & 1 & 6 & 0 & 1 & 1.95 & 3.3 \\
\hline \multirow{3}{*}{$\begin{array}{l}\text { Shallow water habitat } \\
\text { mapping }\end{array}$} & 2011 & 7 & 2 & 7 & 0 & 0 & 3.11 & 5.5 \\
\hline & 2012 & 4 & 1 & 4 & 0 & 0 & 1.95 & 4.2 \\
\hline & Total & 11 & 3 & 11 & 0 & 0 & 5.06 & 9.7 \\
\hline \multirow{3}{*}{$\begin{array}{l}\text { Missouri River spring } \\
\text { rise channel } \\
\text { morphodynamics } \\
\text { (Elliott and others, } \\
\text { 2009) }\end{array}$} & 2006 & 4 & 0 & 4 & 0 & 0 & 6.15 & 15.6 \\
\hline & 2007 & 4 & 0 & 4 & 0 & 0 & 6.47 & 15.8 \\
\hline & Total & 8 & 0 & 8 & 0 & 0 & 12.62 & 31.4 \\
\hline \multirow{4}{*}{$\begin{array}{c}\text { Missouri River } \\
\text { general channel } \\
\text { dynamics }\end{array}$} & 2003 & 1 & 0 & 1 & 0 & 0 & 2.05 & 3.6 \\
\hline & 2008 & 7 & 7 & 0 & 0 & 0 & 0.86 & 4.61 \\
\hline & 2009 & 2 & 2 & 0 & 0 & 0 & 0.45 & 0.7 \\
\hline & Total & 10 & 9 & 1 & $\mathbf{0}$ & 0 & 3.35 & 8.91 \\
\hline \multirow{8}{*}{$\begin{array}{l}\text { Missouri River side- } \\
\text { channel chutes } \\
\text { (Lisbon, Jameson, } \\
\text { Overton, and Tate } \\
\text { Island) }\end{array}$} & 2004 & 2 & 0 & 2 & 0 & 0 & 6.38 & 10.6 \\
\hline & 2005 & 2 & 0 & 2 & 0 & 0 & 2.5 & 4.8 \\
\hline & 2007 & 1 & 0 & 1 & 0 & 0 & 0.09 & 1.9 \\
\hline & 2009 & 3 & 3 & 2 & 0 & 0 & 0.31 & 4.1 \\
\hline & 2010 & 1 & 1 & 1 & 0 & 0 & 0.19 & 3 \\
\hline & 2011 & 8 & 8 & 7 & 0 & 0 & 1.94 & 5.3 \\
\hline & Total & 17 & 12 & 15 & $\mathbf{0}$ & $\mathbf{0}$ & 11.41 & 29.7 \\
\hline & $\begin{array}{c}\text { Grand } \\
\text { Total }\end{array}$ & 252 & 47 & 239 & 162 & 36 & 142.22 & 327.74 \\
\hline
\end{tabular}


Table 13. Non-reach map hydroacoustic data collections for the Missouri River and tributaries

\begin{tabular}{llcl}
\multicolumn{1}{c}{ Category } & Year & Number of days of data collection \\
\hline $\begin{array}{l}\text { Characterization of Upper Missouri and Yellowstone } \\
\text { River velocities for dispersion calculations }\end{array}$ & 2013 & 5 \\
\hline & 2010 & 12 & 7 \\
Pallid sturgeon migratory habitat measurements on & 2011 & 21 \\
the Yellowstone and Lower Missouri Rivers & 2012 & 5 & 34 \\
(McElroy and others, 2012) & 2013 & 6 \\
\hline & 2005 & 11 \\
& 2006 & 4 \\
Missouri River side-channel chutes (Lisbon, & 2007 & 9 \\
Jameson, Overton, and Tate Island; Jacobson and & 2008 & 2 \\
others 2004, Jacobson and others, 2006) & 2009 & 9 \\
& 2011 & 9 \\
\hline
\end{tabular}

Table 14. Reach-scale hydroacoustic maps by geographic Missouri and Yellowstone River segment

\begin{tabular}{|c|c|c|c|c|}
\hline Segment name & River segment & $\begin{array}{l}\text { Upper } \\
\text { river mile }\end{array}$ & $\begin{array}{l}\text { Lower } \\
\text { river mile }\end{array}$ & $\begin{array}{c}\text { Number of } \\
\text { miles } \\
\text { mapped }\end{array}$ \\
\hline Missouri River Osage & $\begin{array}{l}\text { Missouri River Osage River to Mississippi } \\
\text { River }\end{array}$ & 130 & 0 & 21.52 \\
\hline Missouri River Grand & Missouri River Grand River to Osage River & 249.9 & 130 & 114.11 \\
\hline Missouri River Kansas & Missouri River Kansas River to Grand River & 367.4 & 249.9 & 33.00 \\
\hline Missouri River Platte & Missouri River Platte River to Kansas River & 594.7 & 367.4 & 10.40 \\
\hline Missouri River Sioux & $\begin{array}{l}\text { Missouri River Big Sioux River to Platte } \\
\text { River }\end{array}$ & 733.9 & 594.7 & 102.00 \\
\hline Missouri River Ponca & $\begin{array}{l}\text { Missouri River Ponca State Park to Big } \\
\text { Sioux River }\end{array}$ & 752.8 & 733.9 & 20.60 \\
\hline Missouri River Gavins & $\begin{array}{l}\text { Missouri River Gavins Point Dam to Ponca } \\
\text { State Park }\end{array}$ & 811.1 & 752.8 & 20.90 \\
\hline Lower Yellowstone River & $\begin{array}{l}\text { Yellowstone River Intake Dam to Missouri } \\
\text { River }\end{array}$ & 73 & 0 & 5.22 \\
\hline Total & & & & 327.74 \\
\hline
\end{tabular}


Charles, Mo., in 2012 and on the Missouri River a few miles upstream from the Platte River, as well as in the Platte River in 2013 and 2014. Habitats were mapped over a range of discharges representative of those during the period of larval sampling. Once during each season, a more extensive reach was mapped at a common seasonal discharge (approximately median navigation seasonal discharge) upstream and downstream from the sampling location.

6. Shallow water habitat: 2011-14. Habitat mapping at targeted locations to investigate regions with large amounts of recirculating flow and shallow water habitat. Some mapping has occurred in coordination with U.S. Fish and Wildlife Service's age-0 sturgeon sampling efforts on the Missouri River.

In addition, the following datasets were collected to assess various habitat dynamics concerns on the Missouri River:

1. Missouri River spring rise-These datasets included reach-scale bathymetric and velocity maps generated for hydrodynamic modeling, randomly selected repeat cross sections, longitudinal profiles measured to monitor channel dynamics over a range of flows including pulsed spring rise experimental flows from Gavins Point Dam, and hydrodynamic model results (Elliott and others, 2009; Jacobson and others, 2009).

2. Missouri River side-channel chute monitoring-These data were collected in or adjacent to constructed and natural chutes on the Missouri River. Data are composed of crosssectional surveys including surface topography and chute bathymetry, ADCP discharge transects at a range of flows, and longitudinal channel profiles (Jacobson and others, 2004; Jacobson and Galat, 2006).

Missouri River Hydroacoustic Habitat Dynamics System Holdings 2005-13

Single-beam depth soundings. - Depth data have been generated from a survey-grade Odom Hydrotrac ${ }^{\circledR}$ echosounder (Teledyne Odom Hydrographic Systems Inc., Baton Rouge, La.) using positioning from either RTK GPS to provide horizontal and vertical positioning for water-surface and bed elevations or a differential global-position system (DGPS) for horizontal positioning only for depth maps. Single-beam data have been collected from a transducer mounted off the side of a research vessel along planned transects generated using Hypack ${ }^{\circledR}$ software (Hypack Inc., Middletown, Conn.). Transects have been generally perpendicular to flow with variable (5 to $50 \mathrm{~m}$ ) spacing depending on project requirements. Longitudinal profiles were driven occasionally along lines parallel to flow. Echosounders were calibrated using standard bar-check procedures documented in Reuter and others (2008). Data collection rates of 5 hertz were usually used for cross-sectional transects. Raw single-beam files have been archived in Hypack ${ }^{\circledR}$, *.RAW data format and edited single-beam files are stored in Hypack ${ }^{\circledR}$, *.EDT format and exported from Hypack ${ }^{\circledR}$ as edited text files for import into software for map production and analysis.

Multibeam echosounder soundings. - Multibeam depth and elevation soundings have been collected using a RESON 7125 SeaBat ${ }^{\circledR}$ Echosounder and a POS MV Wavemaster ${ }^{\circledR}$ Motion Sensor. RTK GPS was usually used for positioning although some sites were geo-referenced using DGPS where it was not possible to install a base station. The multibeam echosounder was calibrated for pitch, heave, and roll relative to the mount by a patch test procedure conducted using Hypack ${ }^{\circledR}$ software each time the mounting system on the research vessel was modified. Multibeam swaths were usually collected in longitudinal transects driving in an upstream or downstream direction parallel to flow and data were 
logged in Hypack ${ }^{\circledR}$ and archived as unedited *.HSX files. Multibeam data have been manually cleaned to remove spurious soundings in Hypack ${ }^{\circledR}$ to generate edited ${ }^{*}$.HS2 files.

ADCP data.- -Velocity data have been collected using a Rio Grande ${ }^{\circledR}$ 1,200 or 600 kilohertz ADCP (Teledyne RD Instruments, Poway, Calif.) depending on discharge conditions. Data have been archived both as WinRiver ${ }^{\circledR}$ files and generic ASCII outputs from WinRiver ${ }^{\circledR}$. Older raw ADCP data are housed as WinRiver ${ }^{\circledR}$ *.000 files. Data collected after 2007 have been collected using WinRiver II® and are archived in WinRiver II ${ }^{\circledR} *$.mmt files with *.PD0 and *.GPS.TXT files. ADCP transects were driven perpendicular to flow using Hypack ${ }^{\circledR}$ navigation software. Discharge transects were driven as 4 reciprocal transects. Magnetic variation was calculated for each reach using geomagnetic software data or from the National Oceanic and Atmospheric Administration's National Geophysical Data Center Web site. A compass calibration procedure was performed in Hypack ${ }^{\circledR}$ at the beginning of each survey.

Substrate.-A RoxAnn ${ }^{\circledR}$ (Marine Microsystems and Sonavision Ltd., Aberdeen, United Kingdom) bed classification unit was used from 2002-08 to characterize roughness and hardness data from single-beam soundings. These data have been incorporated in Hypack files. More information about RoxAnn ${ }^{\circledR}$ substrate information can be found in Reuter and others (2008).

GPS data.- GPS data include RTK or DGPS survey data to establish temporary or semipermanent bench marks for surveying and for topographic ground surveys. DGPS instrumentation provides submeter or better horizontal positioning and used either Trimble ${ }^{\circledR}$ (Trimble Navigation Ltd, Sunnyvale, Calif.) AgGPS ${ }^{\circledR} 132$ or Trimble ${ }^{\circledR}$ DS-132 receivers and OmniSTAR ${ }^{\circledR}$ (OmniSTAR Inc., Houston, Tex.) or Fugro ${ }^{\circledR}$ (Fugro World Wide, Leidschendam, Netherlands) satellites for differential correction. Many surveys utilized a Trimble ${ }^{\circledR}$ 12-channel RTK GPS system to provide subdecimeter or better horizontal and vertical positioning.

Side-scan sonar. - Sides-scan sonar data are available for most reaches that are believed to include spawning sites. Side-scan datasets were collected using longitudinal transects using a 900kilohertz Marine Sonics ${ }^{\circledR}$ towfish (Marine Sonic Technology, Ltd., White Marsh, Va.). DGPS positioning was used for geo-referencing and is approximate because position of the towfish has not been accounted for.

Maps. - Geospatial maps have been generated from hydroacoustic data using automated scripts written in Perl ${ }^{\circledR}$ (Perl Foundation, Walnut, Calif.) from 2001-05. Scripts were written in Python ${ }^{\circledR}$ (Python Software Foundation, Hampton, N.H.) and utilized from 2005-15. Shapefiles of edited depth data or exported velocity bin and ensemble data were generated and data were gridded using a kriging algorithm in ArcMap ${ }^{\circledR}$ (see Reuter and others, 2008 for details). Gridded map products are stored in ArcGIS ${ }^{\circ}$ grid format:

1. Depth — Single-beam depth maps have been usually gridded to a 5-m cell size and may have been derived from either single-beam echosounder data or 4-beam ADCP solutions.

2. Elevation-Elevation maps have been generated using RTK GPS for water-surface and bed elevations in Hypack ${ }^{\circledR}$.

3. Velocity-Maps of depth-averaged velocity were usually gridded to a 5-m cell size and derived from ADCP data.

4. Multibeam bathymetry maps-Multibeam maps were usually gridded from edited multibeam data to a 1 or 0.5 meter cell size using the Combined Uncertainty and Bathymetric Estimator (CUBE) algorithm as implemented in Fledermaus ${ }^{\circledR}$ (QPS, Plymouth, N.H.).

5. Substrate Maps-Substrate maps were generated for some projects using RoxAnn ${ }^{\circledR}$ E1 and E2 roughness and hardness information and side-scan sonar maps (see Reuter and others, 2008 for details). 
6. Side-scan sonar maps - Side-scan sonar data have been archived both as high-resolution images and geo-referenced mosaics (see Reuter and others, 2008 for details).

\section{Evaluation and Contribution to Effects Analysis}

The CSRP data and analyses should be useful to address hypotheses related to reproductive cues and spawning habitats. CSRP evaluations of free-embryo distributions and larval habitat selection directly address how habitat management may relate to increased survival of early-life stages. In addition to published results, the EA may benefit from additional analysis that integrates CSRP biological and physical data with PSPAP and HAMP data. CSRP assessments of habitat dynamics and habitat selection provide understanding of linkages between flow management, channel engineering, and biotic responses for reproductive adult fish.

\section{Range-Wide Pallid Sturgeon Genetic Sampling}

Development of genetics methods, decreased analysis costs, and concerted genetic sampling efforts have resulted in broadened understanding of genetic structuring of the pallid sturgeon over the past 5 years. Documentation of genetic structure is central to population augmentation strategies. Moreover, understanding how genetically defined subpopulations formerly and presently relate to the template of physical habitat is critical to understanding where and what types of habitats need to be restored in the Missouri River. Genetic studies have suggested that a genetic structuring of pallid sturgeon populations exists that predates migratory barriers (Campton and others, 2000; Tranah and others, 2001; Schrey, 2007; Schrey and Heist, 2007). Recognition of genetic structure suggests that reproductive isolation mechanisms were established prior to construction of the dams on the Missouri River. The contemporary genetic structure has likely been altered by early population augmentation practices which resulted in considerable transfer of genetic stocks from the Middle Mississippi and Upper Missouri Rivers into the Lower Missouri River (Schrey and Heist, 2007).

Genetic introgression (hybridization) between pallid and shovelnose sturgeon is occurring and likely has been occurring for several generations (Carlson and others, 1985; Tranah and others, 2004; Schrey and others, 2011). Evidence of genetic introgression has been found in all management units but appears to be highest in the southern extreme of the range in the Lower Mississippi River (Schrey and others, 2011).

\section{Sampling Protocol}

Field Collection: Field-identified pallid sturgeon, without detectable hatchery marks, collected under an Endangered Species Act of 1973 (16 U.S.C. ch. $35 \S 1531$ ) permit range wide must be sampled for genetics. All individuals and institutions sampling pallid sturgeon must follow the approved, "Biological Procedures and Protocols for Researchers and Managers Handling Pallid Sturgeon," (U.S. Fish and Wildlife Service, 2012) as prepared by the Pallid Sturgeon Recovery Team and approved by Region 6 of the USFWS. Annual capture data are reported to the Missouri River Fish and Wildlife Conservation Office, USFWS, Bismarck, N. Dak., for incorporation into the National Pallid Sturgeon Database. At a minimum, a subset or portion of each genetic sample must be sent to the Conservation Genetics Lab at the USFWS Northeast Fishery Center (Missouri River) or the Conservation Genetics Lab at the USFWS Warm Springs Regional Fisheries Center (Mississippi and Atchafalaya Rivers) following protocols in U.S. Fish and Wildlife (2012) for inclusion in the pallid sturgeon genetic material repository (archive). A copy of the completed data sheet included in appendix of the Handling Protocols or the equivalent must be included with the sample. The sample along with the data reported in the 
appendix is maintained by the respective tissue repository (table 15). In addition to the required samples from field-identified pallid sturgeon, some individuals and institutions may submit samples from suspected pallid x shovelnose sturgeon hybrids and known hatchery progeny (marked) for inclusion in the tissue repositories. These samples are not routinely or systematically collected or submitted.

Potential Broodstock: Tissue samples from pallid sturgeon from the Great Plains Management Unit (GPMU) identified as potential broodstock in the Pallid Sturgeon Conservation Augmentation Program (PSCAP) are submitted to USFWS Northeast Fishery Center. Although their analysis is prioritized, the samples are submitted in the same manner as the required repository samples. In the Central Lowland (CLMU) and Interior Highlands Management Units (IHMU), a subset or subsample of the required tissue sampled from pallid sturgeon identified as potential broodstock in the PSCAP are submitted to Southern Illinois University Carbondale (table 15). No propagation currently occurs in the Coastal Plains Management Unit (U.S. Fish and Wildlife Service, 2008).

Eggs, Free embryos and Larvae: Sturgeon sampled as eggs, free embryos, and larvae for genetics analysis are not sent to the national tissue repositories. If genetics analyses are requested, the samples are sent by the collecting individual or agency to the contracting laboratory or collaborating research partner for analyses. In the Lower Missouri River, PSPAP and HAMP age-0 Scaphirhynchus samples are sent to Southern Illinois University Carbondale for genetic identification, whereas Upper Missouri River age-0 and egg samples typically are sent to the USFWS Northeast Fishery Center. There is currently no provision for archiving the tissue or centralized reporting of the collection information for these life stages.

Table 15. Summary of pallid sturgeon genetic sample processing, as of September 2014

\begin{tabular}{|c|c|c|c|c|}
\hline Facility & $\begin{array}{c}\text { Geographic } \\
\text { Provider }\end{array}$ & Primary Purpose & $\begin{array}{c}\begin{array}{c}\text { Number Samples } \\
\text { Processed }\end{array} \\
\end{array}$ & $\begin{array}{c}\text { Number of Samples } \\
\text { Archived }\end{array}$ \\
\hline USFWS Northeast & Missouri Rivers & $\begin{array}{c}\text { Species Verification } \\
\text { and Origin }\end{array}$ & \multirow{2}{*}{ 1160/annually } & \multirow{2}{*}{ Over 5000} \\
\hline Fishery Center & $\begin{array}{c}\text { Great Plains } \\
\text { Management Unit }\end{array}$ & Propagation Suitability & & \\
\hline $\begin{array}{c}\text { Warm Springs } \\
\text { Conservation Genetics } \\
\text { Laboratory }\end{array}$ & $\begin{array}{c}\text { Mississippi and } \\
\text { Atchafalaya Rivers }\end{array}$ & $\begin{array}{l}\text { Species Verification } \\
\text { and Origin }\end{array}$ & $\begin{array}{l}\text { Approximately } 430 \\
\text { since } 2006\end{array}$ & $\begin{array}{l}\text { Approximately } 978 \\
\text { since } 2006\end{array}$ \\
\hline \multirow{2}{*}{$\begin{array}{l}\text { Southern Illinois } \\
\text { University -Center for } \\
\text { Fisheries, Aquaculture, } \\
\text { \& Aquatic Sciences }\end{array}$} & $\begin{array}{l}\text { Central Lowlands } \\
\text { Management Unit }\end{array}$ & Propagation Suitability & ? & ? \\
\hline & $\begin{array}{l}\text { Interior Highlands } \\
\text { Management Unit }\end{array}$ & Propagation Suitability & ? & ? \\
\hline
\end{tabular}

\section{Analyses and Data Reporting}

Genetic samples analyzed for species identification and parentage analysis (to identify hatcheryorigin pallid sturgeon without detected hatchery marks), at a minimum, must be analyzed for Microsatellite deoxyribonucleic acid (DNA) at the 17 standard loci listed in Appendix II (U.S. Fish and Wildlife Service, 2012). Among-laboratory standardization has been completed at these 17 loci with the participation of laboratories at the tissue repositories and in the PSCAP broodstock programs. Genetic baselines used for species determination are developed in concurrence among standardized laboratories.

Unfortunately, genotypes are not available from all broodstock fish used in past propagation efforts. The presence of related, unmarked progeny from genetically undocumented PSCAP broodstock alters the genetic baseline and obscures natural population structure (Schrey and Heist, 2007; DeHaan 
and others, 2008; U.S. Fish and Wildlife Service, 2014). Recent efforts reconstructing the parental genotypes of undocumented PSCAP broodstock has remediated this uncertainty. At this time, only seven parental genotypes, representing several thousand progeny, are missing from the genetic baseline for range-wide captive breeding efforts from three year classes (1992, 1997, and 2001) (K. Chojnacki, USGS, written commun., 2015). Parental reconstruction combined with recent work to develop a more robust range-wide morphological and genetic baseline shows strong evidence of increasing genetic introgression with shovelnose sturgeon downstream in the Lower Missouri and Mississippi Rivers (E. Heist, Southern Illinois University Carbondale, written commun., 2015). Current genetic analyses are inadequate to identify and characterize genetic introgression between the species, thus the nature of hybridization and the threat to pallid sturgeon viability and recovery is uncertain (Schrey and others, 2011).

Samples submitted to the Tissue Repositories are analyzed dependent upon available funding and approved requests. Currently, samples submitted from potentially wild (that is, fish without detectable hatchery marks), field-collected pallid sturgeon from the Missouri River are routinely analyzed for species and parentage by the USFWS Northeast Fishery Center. Results of the analyses (species and parentage) are reported to the individual or institution that submitted the sample and to the project leader for the National Pallid Sturgeon Database. Genotypes are not reported. Samples submitted to the Mississippi and Atchafalaya River repository are not routinely analyzed. Tissue samples from the national repositories are available upon written request. All requests for genetic material must be approved by the Pallid Sturgeon Recovery Team. Once approved, subsections of the tissues are sent to the requesting researcher. Results of analyses may be, but are not necessarily required to be, reported to either the tissue repositories or the National Pallid Sturgeon Database.

All pallid sturgeon used for broodstock in the PSCAP must currently be genotyped and breeding matrices screened for relatedness prior to the generation of hatchery crosses. Tissues from males used for milt cryopreservation in the PSCAP are submitted to the Tissue Repository and genotyped either at the time of collection or as needed. Existing parental genotypes for PSCAP broodstock are held by the USFWS Northeast Fishery Center (GPMU, CLMU, and IHMU).

Data or analytical results from eggs, free embryos or larvae are not currently reported to the project leader of the National Pallid Sturgeon Database. The remainder of whole organisms or tissues from eggs, embryos or larvae determined to be pallid sturgeon are not currently required to be submitted to the tissue repositories upon completion of the analyses.

Contact information for the tissue, genotype, and national databases are summarized:

\section{National Pallid Sturgeon Database}

Missouri River FWCO

Steve Krentz, Project Leader

U.S. Fish and Wildlife Service

3425 Miriam Avenue., Bismarck, ND 58501

Phone: (701)-355-8547

e-mail: Steven_Krentz@fws.gov 


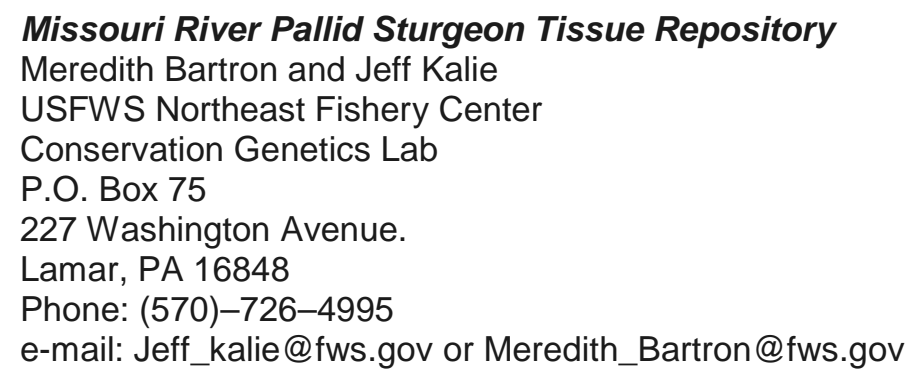

Mississippi and Atchafalaya River Pallid Sturgeon Tissue Repository

The landscape-scale distribution of genotypes has been critical information for the PSCAP as it illustrates the genetic structure of the pallid sturgeon population. The data are important for management agencies to inform decisions about boundaries on distinct population segments, fundamental genetic definition of the species, and extent of genetic diversity achieved through the population augmentation program. Of particular importance is the role of genetics to determine if fish present in the system are of wild or hatchery origin, to evaluate hybridization, to use as a tracer for evaluating dispersal of individuals stocked in the system, and to determine if recruitment is occurring. The information is especially useful to the EA in indicating the extent to which breeding populations mix in the Lower Missouri and Mississippi Rivers. It is a concern that not all genotype, location, and stocking data are archived in a single, centralized and accessible database and are not linked to the National Pallid Sturgeon Database. The fragmented distribution of pallid sturgeon genetic information may impede efforts to compile relevant models of population dynamics. 


\section{Related Datasets, Analyses, and Species}

Although the focus on the Missouri River pallid sturgeon EA is on populations supported by processes in the Missouri River and which can be affected by Missouri River management actions, our understanding of the species is affected by understanding from datasets and analyses on neighboring rivers and potentially from comparative species. Movements of pallid sturgeon between the main stem and tributaries like the Yellowstone and Platte Rivers (Fuller and others, 2008; DeLonay and others, 2015) and movements from the Lower Missouri River to the Mississippi River indicate the potential connections between conditions and processes beyond the Missouri River to pallid sturgeon found in the Missouri River (DeLonay and others, 2009). Studies on pallid sturgeon in the Platte River (Peters and Parham, 2007; Hamel and Pegg, 2010) and in the Mississippi River (Garvey and others, 2009; Phelps and others, 2010; Koch and others, 2012; Phelps and others, 2012; Sechler and others, 2012) are particularly important for establishing where factors unrelated to Missouri River management influence pallid sturgeon reproduction and growth.

Because of its close ancestry and similar life cycle, the sympatric shovelnose sturgeon has been used as a comparative species for some purposes (DeLonay and others, 2009). Given that pallid and shovelnose sturgeon are known to hybridize, it is clear that the two species share some life-stage traits as reproductive adults, and it is probable that useful information on reproductive ecology can be gleaned from shovelnose sturgeon studies (Bajer and Wildhaber, 2007; Wildhaber and others, 2011c). Direct comparison between the two species in early-life stages is less established, and the species are known to diverge during the juvenile stage when pallid sturgeon progress from a macroinvertebrate-dominated diet to a fish-dominated diet (Gerrity and others, 2006). Life histories of other sturgeon species such as white sturgeon, Acipenser fulvescens (lake sturgeon), gulf sturgeon, Atlantic sturgeon, and Acipenser brevirostrum (shortnose sturgeon) may also provide insights into factors that are difficult to establish for the pallid sturgeon; however, reasoning from comparative species and (or) other rivers always introduces elements of uncertainty.

\section{Conclusions}

Scientific information on pallid sturgeon and its environment has grown substantially over the last decade but challenges remain for the Missouri River Effects Analysis Team to develop useful, quantitative models linking management actions to population processes. Despite documented spawning, natural recruitment, if not equal to zero, is so small as to be insufficient to maintain the population. Lack of recruitment confounds attempts to link recruitment to environmental conditions through correlative approaches. Emerging laboratory studies of early-life stage processes promise to provide insight into early-life stage survival, but extrapolation of laboratory conditions to the field is challenging. Substantial quantities of information exist and are under development for characterizing and quantifying habitat dynamics for pallid sturgeon, but the functional definitions of habitat classes, and how quality and quantity are linked to demographic parameters, remain speculative. Critical demographic parameters for population models are uncertain, especially for survival of early-life stages. The functional linkages from management actions to changes in physical, chemical, and biotic habitat, to growth, condition, mortality, and reproductive behaviors, while depicted in conceptual models, will be challenging or impossible to quantify with existing data. In addition, there is an overarching uncertainty about how physical management actions interact with propagation management actions in view of evolving understanding of genetic structuring of the pallid sturgeon population. 


\section{References Cited}

Bajer, P.G., and Wildhaber, M.L., 2007, Population viability analysis of Lower Missouri River shovelnose sturgeon with initial application to the pallid sturgeon: Journal of Applied Ichthyology, v. 23, no. 4, p. 457-464, [Also available at http://dx.doi.org/10.1111/j.14390426.2007.00879.x].

Barton, B.A., Bollig, H., Hauskins, B.L., and Jansen, C.R., 2000, Juvenile pallid (Scaphirhynchus albus) and hybrid pallid x shovelnose (S. albus x platorynchus) sturgeons exhibit low physiological responses to acute handling and severe confinement: Comparative Biochemistry and Physiology, v. 126, no. Part A, p. 125-134, [Also available at http://dx.doi.org/10.1016/S10956433(00)00192-6].

Bergman, H.L., Boelter, A.M., Parady, K., Fleming, C., Keevin, T., Latka, D.C., Korschgen, C.E., Galat, D.L., Hill, T., Jordan, G., Krentz, S., Nelson-Stastny, W., Olson, M., Mestl, G., K., R., and Berkley, J., 2008, Research needs and management strategies for pallid sturgeon recovery.: in Second Pallid Sturgeon Workshop, University of Wyoming, Laramie, William D. Ruckelshaus Institute of Environment and Natural Resources, 36 p.

Bevelhimer, M.S., 2002, A bioenergetics model for white sturgeon (Acipenser transmontanus): Assessing differences in growth and reproduction among Snake River reaches: Journal of Applied Ichthyology, v. 18, no. 4-6, p. 550-556, [Also available at http://dx.doi.org/10.1046/j.1439-0426.2002.00392.x].

Blevins, D.W., 2011, Water quality requirements, tolerances, and preferences of pallid sturgeon (Scaphirhychus albus) in the Lower Missouri River: U.S. Geological Survey Scientific Investigations Report 2011-5186, 20 p.

Bonnot, T.W., Wildhaber, M.L., Millspaugh, J.J., DeLonay, A.J., Jacobson, R.B., and Bryan, J.L., 2011, Discrete choice modeling of shovelnose sturgeon habitat selection in the Lower Missouri River: Journal of Applied Ichthyology, v. 27, no. 2, p. 291-300, [Also available at http://dx.doi.org/10.1111/j.1439-0426.2010.01637.x].

Boucher, M.A., McAdam, S.O., and Shrimpton, J.M., 2014, The effect of temperature and substrate on the growth, development, and survival of larval white sturgeon: Aquaculture, v. 430, p. 139148, [Also available at $h t t p: / / d x . d o i . o r g / 10.1016 / j . a q u a c u l t u r e .2014 .03 .011]$.

Bowen, Z.H., Bovee, K.D., and Waddle, T.J., 2003, Effects of channel modification on fish habitat in the Upper Yellowstone River: U.S. Geological Survey Open-File Report 03-476, 30 p.

Braaten, P.J., Fuller, D.B., Holte, L.D., Lott, R.D., Viste, W., Brandt, T.F., and Legare, R.G., 2008, Drift dynamics of larval pallid sturgeon and shovelnose sturgeon in a natural side channel of the Upper Missouri River, Montana: North American Journal of Fisheries Management, v. 28, no. 3, p. 808-826, [Also available at $h t t p: / / d x . d o i . o r g / 10.1577 / m 06-285.1]$.

Braaten, P.J., Fuller, D.B., Lott, R.D., Haddix, T.M., Holte, L.D., Wilson, R.H., Bartron, M.L., Kalie, J.A., DeHaan, P.W., Ardren, W.R., Holm, R.J., and Jaeger, M.E., 2012, Natural growth and diet of known-age pallid sturgeon (Scaphirhynchus albus) early life stages in the Upper Missouri River basin, Montana and North Dakota: Journal of Applied Ichthyology, v. 28, no. 4, p. 496504, [Also available at $h t t p: / / d x . d o i . o r g / 10.1111 / j .1439-0426.2012 .01964 . x]$.

Braaten, P.J., Fuller, D.B., Lott, R.D., and Jordan, G.R., 2009, An estimate of the historic population size of adult pallid sturgeon in the Upper Missouri River Basin, Montana and North Dakota: Journal of Applied Ichthyology, v. 25, p. 2-7, [Also available at http://dx.doi.org/10.1111/j.1439-0426.2009.01195.x]. 
Braaten, P.J., Fuller, D.B., Lott, R.D., Ruggles, M.P., and Holm, R.J., 2010, Spatial distribution of drifting pallid sturgeon larvae in the Missouri River inferred from two net designs and multiple sampling locations: North American Journal of Fisheries Management, v. 30, no. 4, p. 10621074, [Also available at $h t t p: / / d x . d o i . o r g / 10.1577 / M 09-149.1]$.

Bramblett, R.G., and White, R.G., 2001, Habitat use and movements of pallid and shovelnose sturgeon in the Yellowstone and Missouri Rivers in Montana and North Dakota: Transactions of the American Fisheries Society, v. 130, no. 6, p. 1006-1025, [Also available at http://dx.doi.org/10.1577/1548-8659(2001)130<1006:Huamop>2.0.Co;2].

Bryan, J.L., Wildhaber, M.L., Gladish, D.W., Holan, S.H., and Ellerseick, M., 2010, The power to detect trends in Missouri River Fish populations within the Pallid Sturgeon Population Assessment Program: U.S. Geological Survey Open-File Report 2010-1020, 414 p.

Bryan, J.L., Wildhaber, M.L., Papoulias, D.M., DeLonay, A.J., Tillitt, D.E., and Annis, M.L., 2007, Estimation of gonad volume, fecundity, and reproductive stage of shovelnose sturgeon using sonography and endoscopy with application to the endangered pallid sturgeon: Journal of Applied Ichthyology, v. 23, no. 4, p. 411-419, [Also available at http://dx.doi.org/10.1111/j.1439-0426.2007.00889.x].

Campton, D.E., Bass, A.L., Chapman, F.A., and Bowen, B.W., 2000, Genetic distinction of pallid, shovelnose, and Alabama sturgeon: Emerging species and the U.S. Endangered Species Act: Conservation Genetics, v. 1, p. 17-32, [Also available at http://link.springer.com/article/10.1023\%2FA\%3A1010121417487].

Carlson, D.M., Pflieger, W.L., Trial, L., and Haverland, P.S., 1985, Distribution, biology and hybridization of Scaphirhynchus albus and S. platorynchus in the Missouri and Mississippi Rivers: Environmental Biology of Fishes, v. 14, no. 1, p. 51-59, [Also available at http://dx.doi.org/10.1007/Bf00001576].

Chipps, S.R., Klumb, R.A., and Wright, E.B., 2008, Development and application of juvenile pallid sturgeon bioenergetics model: South Dakota Game, Fish and Parks, 40 p.

Colombo, R.E., Garvey, J.E., Jackson, N.D., Brooks, R., Herzog, D.P., Hrabik, R.A., and Spier, T.W., 2007, Harvest of Mississippi River sturgeon drives abundance and reproductive success: A harbinger of collapse?: Journal of Applied Ichthyology, v. 23, no. 4, p. 444-451, [Also available at $h t t p: / / d x . d o i . o r g / 10.1111 / j .1439-0426.2007 .00899 . x]$.

Constant, G.C., Kelso, W.E., Rutherford, D.A., and Bryan, C.F., 1997, Habitat, movement and reproductive status of pallid sturgeon (Scaphirhynchus albus) in the Mississippi and Atchafalaya Rivers: Louisiana State University, 87 p.

Crossman, J.A., and Hildebrand, L.R., 2014, Evaluation of spawning substrate enhancement for white sturgeon in a regulated river: Effects on larval retention and dispersal: River Research and Applications, v. 30, no. 1, p. 1-10, [Also available at http://dx.doi.org/10.1002/rra.2620].

DeHaan, P.W., Jordan, G.R., and Ardren, W.R., 2008, Use of genetic tags to identify captive-bred pallid sturgeon (Scaphirhynchus albus) in the wild: Improving abundance estimates for an endangered species: Conservation Genetics, v. 9, no. 3, p. 691-697, [Also available at http://dx.doi.org/10.1007/s10592-007-9374-3].

DeLonay, A.J., Jacobson, R.B., Chojnacki, K.A., Annis, M.L., Braaten, P.J., Elliott, C.M., Fuller, D.B., Haas, J.D., Haddix, T., Ladd, H.L.A., McElroy, B.J., Mestl, G.E., Papoulias, D.M., Rhoten, J.C., and Wildhaber, M.L., 2014, Ecological requirements for pallid sturgeon reproduction and recruitment in the Missouri River: Annual report 2013: U.S. Geological Survey Open-File Report 2014-1106, 96 p. 
DeLonay, A.J., Jacobson, R.B., Chojnacki, K.A., Braaten, P.J., Bulliner, E.A., Elliott, C.M., Erwin, S.O., Fuller, D.B., Haas, J.D., Ladd, H.L.A., Mestl, G.E., Papoulias, D.M., and Wildhaber, M.L., 2015, Ecological requirements for pallid sturgeon reproduction and recruitment in the Missouri River: A synthesis of science, 2005-2012: U.S. Geological Survey Scientific Investigations Report 2015-5145, 162 p.

DeLonay, A.J., Jacobson, R.B., Papoulias, D.M., Simpkins, D.G., Wildhaber, M.L., Reuter, J.M., Bonnot, T.W., Chojnacki, K.A., Korschgen, C.E., Mestl, G., and Mac, M.J., 2009, Ecological requirements for pallid sturgeon reproduction and recruitment in the Lower Missouri River: A research synthesis 2005-08: U.S. Geological Survey Scientific Investigations Report 2009-5201, $59 \mathrm{p}$.

DeLonay, A.J., Jacobson, R.B., Papoulias, D.M., Wildhaber, M.L., Chojnacki, K.A., Pherigo, E.K., Bergthold, C.L., and Mestl, G.E., 2010, Ecological requirements for pallid sturgeon reproduction and recruitment in the Lower Missouri River: Annual report 2009: U.S. Geological Survey Open-File Report 2010-1215, 76 p.

DeLonay, A.J., Jacobson, R.B., Papoulias, D.M., Wildhaber, M.L., Chojnacki, K.A., Pherigo, E.K., Haas, J.D., and Mestl, G.E., 2012, Ecological requirements for pallid sturgeon reproduction and recruitment in the Lower Missouri River: Annual report 2010: U.S. Geological Survey OpenFile Report 2012-1009, 51 p.

DeLonay, A.J., Papoulias, D.M., Wildhaber, M.L., Annis, M.L., Bryan, J.L., Griffith, S.A., Holan, S.H., and Tillitt, D.E., 2007, Use of behavioral and physiological indicators to evaluate Scaphirhynchus sturgeon spawning success: Journal of Applied Ichthyology, v. 23, no. 4, p. 428-435, [Also available at http://dx.doi.org/10.1111/j.1439-0426.2007.00894.x].

Doyle, M., Murphy, D., Bartell, S., Farmer, A., Guy, C.S., Palmer, M., and Turner, R., 2011, Final report on spring pulses and adaptive management: Missouri River Recovery Program Independent Science Advisory Panel: U.S. Institute for Environmental Conflict Resolution, 58 p., [Also available at http://projects.ecr.gov/moriversciencepanel/pdfs/MRISAPFinalReportSpringPulseAdaptMgt113011.pdf].

Drobish, M.R., 2008, Pallid Sturgeon Population Assessment Project vol. 1.3: U.S. Army Corps of Engineers 1.3, 56 p.

Dryer, M.P., and Sandvol, A.J., 1993, Recovery Plan for the Pallid Sturgeon (Scaphirhynchus albus): U.S. Fish and Wildlife Service, 63 p.

Dzialowski, A.R., Bonneau, J.L., and Gemeinhardt, T.R., 2012, Comparisons of zooplankton and phytoplankton in created shallow water habitats of the Lower Missouri River: Implications for native fish: Aquatic Ecology, v. 47, no. 1, p. 13-24, [Also available at http://dx.doi.org/10.1007/s10452-012-9421-0].

Elliott, C.M., Jacobson, R.B., and DeLonay, A.J., 2004, Physical aquatic habitat assessment, Fort Randall segment of the Missouri River, Nebraska and South Dakota: U.S. Geological Survey Open-File Report 2004-1060, 40 p.

Elliott, C.M., Reuter, J.M., and Jacobson, R.B., 2009, Channel morphodynamics in four reaches of the Lower Missouri River, 2006-07: U.S. Geological Survey Scientific Investigations Report 20095074, $270 \mathrm{p}$.

Erwin, S.O., and Jacobson, R.B., 2014, Influence of channel morphology and flow regime on larval drift of pallid sturgeon on the Lower Missouri River: River Research and Applications, [Also available at http://dx.doi.org/10.1002/rra.2752]. 
French, W.E., 2010, Predation vulnerability and trophic interactions of pallid sturgeon (Scaphirhynchus albus): Brookings, S. Dak., South Dakota State University, M.S. thesis, 59 p.

French, W.E., Graeb, B.D.S., Bertrand, K.N., Chipps, S.R., and Klumb, R.A., 2013a, Size-dependent trophic patterns of pallid sturgeon and shovelnose sturgeon in a large river system: Journal of Fish and Wildlife Management, v. 4, no. 1, p. 41-52, [Also available at http://dx.doi.org/10.3996/022012-jfwm-013].

French, W.E., Graeb, B.D.S., Chipps, S.R., Bertrand, K.N., Selch, T.M., and Klumb, R.A., 2010, Vulnerability of age-0 pallid sturgeon Scaphirhynchus albus to fish predation: Journal of Applied Ichthyology, v. 26, no. 1, p. 6-10, [Also available at http://dx.doi.org/10.1111/j.14390426.2009.01356.x].

French, W.E., Graeb, B.D.S., Chipps, S.R., and Klumb, R.A., 2013b, Vulnerability of age-0 pallid sturgeon Scaphirhynchus albus to predation; effects of predator type, turbidity, body size, and prey density: Environmental Biology of Fishes, v. 97, no. 6, p. 635-646, [Also available at http://dx.doi.org/10.1007/s10641-013-0166-y].

Fuller, D.B., Jaeger, M.E., and Webb, M., 2008, Spawning and associated movement patterns of pallid sturgeon in the lower Yellowstone River. Report submitted to the Western Area Power Administration, upper basin pallid sturgeon work group.: Montana Fish, Wildlife and Parks, 22 p., [Also available at http://moriverrecovery.usace.army.mil/mrrp/MRRP_PUB_DEV.download_documentation?p_fil $e=7094]$.

Gaeuman, D., and Jacobson, R.B., 2005, Aquatic habitat mapping with an acoustic Doppler current profiler: Considerations for data quality: U.S. Geological Survey Open-File Report 2005-1163, $24 \mathrm{p}$.

Gaeuman, D., and Jacobson, R.B., 2007, Quantifying fluid and bed dynamics for characterizing benthic physical habitat in large rivers: Journal of Applied Ichthyology, v. 23, no. 4, p. 359-364, [Also available at $h t t p: / / d x . d o i . o r g / 10.1111 / j .1439-0426.2007 .00888 . x]$.

Galat, D.L., and Lipkin, R., 2000, Restoring ecological integrity of great rivers: Historical hydrographs aid in defining reference conditions for the Missouri River: Hydrobiologia, v. 422, p. 29-48, [Also available at $h t t p: / / d x . d o i . o r g / 10.1023 / A: 1017052319056]$.

Gardner, W.M., 2005, Population abundance and size characteristics of shovelnose sturgeon (Scaphirhynchus platorynchus) in the upper Missouri river, Montana, Scaphirhynchus Conference-Alabama, pallid, and shovelnose sturgeon: St. Louis, 2005,p.

Garvey, J.E., Heist, E.J., Brooks, R.C., Herzog, D.P., Hrabik, R.A., Kilgore, K.J., Hoover, J.J., and Murphy, C.E., 2009, Current status of the pallid sturgeon (Scaphirhynchus albus) in the middle Mississippi River: Habitat, movement, and demographics: U.S. Army Corps of Engineers, 353 p.

Gemeinhardt, T.R., Gosch, N.J.C., Morris, D.M., Miller, M.L., Welker, T.L., and Bonneau, J.L., 2015, Is Shallow Water a Suitable Surrogate for Assessing Efforts to Address Pallid Sturgeon Population Declines?: River Research and Applications, [Also available at http://dx.doi.org/10.1002/rra.2889].

George, S.G., Slack, W.T., and Hoover, J.J., 2012, A note on the fecundity of pallid sturgeon: Journal of Applied Ichthyology, v. 28, no. 4, p. 512-515, [Also available at http://dx.doi.org/10.1111/j.1439-0426.2011.01931.x].

Gerrity, P.C., 2005, Habitat use, diet, and growth of hatchery-reared juvenile pallid sturgeon and indigenous shovelnose sturgeon in the Missouri River above Fort Peck Reservoir: Bozeman, Mont., Montana State University, M.S. thesis, 74 p. 
Gerrity, P.C., Guy, C.S., and Gardner, W.M., 2006, Juvenile pallid sturgeon are piscivorous: A call for conserving native cyprinids: Transactions of the American Fisheries Society, v. 135, no. 3, p. 604-609, [Also available at http://dx.doi.org/10.1577/t05-122.1].

Gerrity, P.C., Guy, C.S., and Gardner, W.M., 2008, Habitat use of juvenile pallid sturgeon and shovelnose sturgeon with implications for water-level management in a downstream reservoir: North American Journal of Fisheries Management, v. 28, no. 3, p. 832-843, [Also available at http://dx.doi.org/10.1577/m07-061.1].

Gosch, N.J.C., Miller, M.L., Dzialowski, A.R., Morris, D.M., Gemeinhardt, T.R., and Bonneau, J.L., 2014, Assessment of Missouri River floodplain invertebrates during historic inundation: Implications for river restoration: Knowledge and Management of Aquatic Ecosystems, no. 412, [Also available at $h t t p: / / d x . d o i . o r g / 10.1051 / K m a e / 2013087]$.

Gosch, N.J.C., Miller, M.L., Gemeinhardt, T.R., Sampson, S.J., and Bonneau, J.L., 2015, Age-0 Sturgeon Accessibility to Constructed and Modified Chutes in the Lower Missouri River: North American Journal of Fisheries Management, v. 35, no. 1, p. 75-85, [Also available at http://dx.doi.org/10.1080/02755947.2014.975300].

Grohs, K.L., 2008, Macroinvertebrate composition and patterns of prey use by juvenile pallid sturgeon (Schaphirhynchus albus) in the Missouri River, South Dakota and Nebraska: Brookings, S. Dak., South Dakota State University, M.S. thesis, 206 p.

Grohs, K.L., Klumb, R.A., Chipps, S.R., and Wanner, G.A., 2009, Ontogenetic patterns in prey use by pallid sturgeon in the Missouri River, South Dakota and Nebraska: Journal of Applied Ichthyology, v. 25, p. 48-53, [Also available at http://dx.doi.org/10.1111/j.14390426.2009.01279.x].

Guy, C.S., Treanor, H.B., Kappenman, K.M., Scholl, E.A., Ilgen, J.E., and Webb, M.A.H., 2015, Broadening the regulated-river management paradigm: A case study of the forgotten dead zone hindering pallid sturgeon recovery: Fisheries, v. 40, no. 1, p. 6-14, [Also available at http://dx.doi.org/10.1080/03632415.2014.987236].

Hadley, G.L., and Rotella, J., 2009, Upper basin pallid sturgeon survival estimation project, 34 p.

Hamel, M.J., and Pegg, M.A., 2010, Sturgeon management in the Platte River, Nebraska: University of Nebraska, Lincoln, 33 p.

Herrala, J.R., Kroboth, P.T., Kuntz, N.M., and Schramm, H.L., 2014, Habitat use and selection by adult pallid sturgeon in the Lower Mississippi River: Transactions of the American Fisheries Society, v. 143, no. 1, p. 153-163, [Also available at http://dx.doi.org/10.1080/00028487.2013.830987].

Herzog, D.P., Hrabik, R., Brooks, R., Spier, T.W., Ostendorf, D.E., Ridings, J.W., Crites, J.W., Beachum, C., and Colombo, R., 2005, Assessment of Scaphirhynchus spp. spawning and rearing locations in the middle Mississippi River: Insights from collection of larval and young-of-theyear fishes, Scaphirhynchus Conference: Alabama, pallid, and shovelnose sturgeon: St. Louis, 2005,p.

Hoover, J.J., George, S.G., and Killgore, K.J., 2007, Diet of shovelnose sturgeon and pallid sturgeon in the free-flowing Mississippi River: Journal of Applied Ichthyology, v. 23, no. 4, p. 494-499, [Also available at $h t t p: / / d x . d o i . o r g / 10.1111 / j .1439-0426.2007 .00893 . x]$.

Hurley, K.L., 1999, Habitat use, selection, and movements of Middle Mississippi River pallid sturgeon and validity of pallid sturgeon age estimates from pectoral fin rays: Carbondale, Ill., Southern Illinois University at Carbondale, M.S. thesis, 81 p.

Jacobson, R.B., and Galat, D.L., 2006, Flow and form in rehabilitation of large-river ecosystems: An example from the Lower Missouri River: Geomorphology, v. 77, no. 3-4, p. 249-269, [Also available at http://dx.doi.org/10.1016/j.geomorph.2006.01.014]. 
Jacobson, R.B., and Galat, D.L., 2008, Design of a naturalized flow regime-an example from the Lower Missouri River, U.S.A.: Ecohydrology, v. 1, no. 2, p. 81-104, [Also available at http://dx.doi.org/10.1002/eco.9].

Jacobson, R.B., Johnson, H.E., Laustrup, M.S., D'Urso, G.J., and Reuter, J.M., 2004, Physical habitats dynamics in four side-channel chutes, Lower Missouri River: U.S. Geological Survey Open-File Report 2004-1071, 66 p.

Jacobson, R.B., Johnson, H.E.I., and Deitrich, B.J., 2009, Hydrodynamic simulations of physical aquatic habitat availabity for pallid sturgeon in the Lower Missouri River at Yankton, S. Dak., Kenslers Bend, Nebr., Little Sioux, Iowa, and Miami, Mo.: U.S. Geological Survey Scientific Investigations Report 2009-5058, 67 p.

Jacobson, R.B., Parsley, M.J., Annis, M.L., Colvin, M.E., Welker, T.L., and James, D., 2015, Development of conceptual ecological models linking management of the Missouri River to pallid sturgeon population dynamics: U.S. Geological Survey Open-File Report 2015-1038, 47 p., [Also available at $h t t p: / / d x . d o i . o r g / 10.3133 / o f r 20151038]$.

Jager, H.I., 2005, Genetic and demographic implications of aquaculture in white sturgeon (Acipenser transmontanus) conservation: Canadian Journal of Fisheries and Aquatic Sciences, v. 62, no. 8, p. 1733-1745, [Also available at $h t t p: / / d x . d o i . o r g / 10.1139 / f 05-106]$.

Jamieson, E.C., Rennie, C.D., and Jacobson, R.B., 2009, Evaluation of flow structure and bed load velocity in the vicinity of a submerged wing dike in a large sand bed river: Water Engineering for a Sustainable Environment, Vancouver, BC, 2009, 33rd International Association for HydroEnvironment Engineering and Research (IAHR) Congress, p. 8.

Jamieson, E.C., Rennie, C.D., Jacobson, R.B., and Townsend, R.D., 2011, 3-D flow and scour near a submerged wing dike: ADCP measurements on the Missouri River: Water Resources Research, v. 47, no. 7, [Also available at $h t t p: / / d x . d o i . o r g / 10.1029 / 2010 w r 010043]$.

Johnson, H., Jacobson, R., and DeLonay, A., 2006, Hydroecological modeling of the Lower Missouri River: Third Federal Interagency Hydrologic Modeling Conference, Reno, Nev., 2006, Subcomittee on Hydrology of the Interagency Advisory Committee on Water Information.

Jordan, G.R., 2013, Draft revised recovery plan for the pallid sturgeon (Scaphirhynchus albus): U.S. Fish and Wildlife Service, Northern Rockies Fish and Wildlife Conservation Office, 96 p.

Jordan, G.R., Klumb, R.A., Wanner, G.A., and Stancill, W.J., 2006, Poststocking movements and habitat use of hatchery-reared juvenile pallid sturgeon in the Missouri River below Fort Randall Dam, South Dakota and Nebraska: Transactions of the American Fisheries Society, v. 135, no. 6, p. 1499-1511, [Also available at $h t t p: / / d x . d o i . o r g / 10.1577 / T 05-201.1]$.

Kappenman, K.M., Toner, M., Illgen, J., and Barrows, F.T., 2011, The effect of diet on growth and survival of first feeding pallid sturgeon Scaphirhynchus albus: Journal of Applied Ichthyology, v. 27, no. 2, p. 755-760, [Also available at http://dx.doi.org/10.1111/j.1439-0426.2011.01699.x] .

Keenlyne, K.D., Grossman, E.M., and Jenkins, L.G., 1992, Fecundity of the pallid sturgeon: Transactions of the American Fisheries Society, v. 121, no. 1, p. 139-140, [Also available at http://dx.doi.org/10.1577/1548-8659(1992)121<0139:fotps>2.3.co;2].

Kennedy, A.J., Sutton, T.M., Stefanavage, T., Fisher, B.E., and Frankland, L.D., 2005, Population characteristics of shovelnose sturgeon from an exploited and unexploited reach of the Wabash River, Indiana, Scaphirhynchus Conference: Alabama, pallid, and shovelnose sturgeon: St. Louis, 2005,p.

Killgore, K.J., Hoover, J.J., George, S.G., Lewis, B.R., and Murphy, C.E., 2005, Habitat and Population attributes of pallid sturgeon in the Lower Mississippi River: in Scaphirhynchus Conference: Alabama, pallid, and shovelnose sturgeon, St. Louis, 2005,p. 
Killgore, K.J., Hoover, J.J., Kirk, J.P., George, S.G., Lewis, B.R., and Murphy, C.E., 2007, Age and growth of pallid sturgeon in the free-flowing Mississippi River: Journal of Applied Ichthyology, v. 23, no. 4, p. 452-456, [Also available at http://dx.doi.org/10.1111/j.1439-0426.2007.00892.x].

Koch, B.T., R.C., B., Oliver, A., Herzog, D., Garvey, J.E., Hrabik, R., Colombo, R., Phelps, Q., and Spier, T., 2012, Habitat selection and movement of naturally occurring pallid sturgeon in the Mississippi River: Transactions of the American Fisheries Society, v. 141, no. 1, p. 112-120, [Also available at $h t t p: / / d x . d o i . o r g / 10.1080 / 00028487.2011 .652008]$.

Koch, J.D., Quist, M.C., Pierce, C.L., Hansen, K.A., and Steuck, M.J., 2009, Effects of commercial harvest on shovelnose sturgeon populations in the Upper Mississippi River: North American Journal of Fisheries Management, v. 29, no. 1, p. 84-100, [Also available at http://dx.doi.org/10.1577/M08-115.1].

Korschgen, C.E., Delonay, A.J., Papoulias, D.M., Jacobson, R.B., Wildhaber, M.L., Simpkins, D.G., Mestl, G.E., Everitt, D.W., Chojnacki, K.A., Annis, M.L., Tillitt, D.E., LaBay, S.R., Blevins, D.W., Bartholomay, R., Neitzert, K., Rus, D., Wilson, R., Anderson, M., Kopish, R., and Haschemeyer, R., 2007, Factors affecting the reproduction, recruitment, habitat, and population dynamics of pallid sturgeon and shovelnose sturgeon in the Missouri River: U.S. Geological Survey Open-File Report 2007-1262, 290 p.

Kynard, B., Henyey, E., and Horgan, M., 2002, Ontogenetic behavior, migration, and social behavior of pallid sturgeon (Scaphirhynchus albus) and shovelnose sturgeon (S. platorynchus) with notes on the adaptive significance of body color: Environmental Biology of Fishes, v. 63, no. 4, p. 389403, [Also available at $h t t p: / / d x . d o i . o r g / 10.1023 / A: 1014950202783]$.

Kynard, B., Parker, E., Pugh, D., and Parker, T., 2007, Use of laboratory studies to develop a dispersal model for Missouri River pallid sturgeon early life intervals: Journal of Applied Ichthyology, v. 23, no. 4, p. 365-374, [Also available at http://dx.doi.org/10.1111/j.1439-0426.2007.00908.x].

MacConnell, E., Hedrick, R.P., Beck, L., and Hudson, C., 2007, Effects of pallid sturgeon iridovirus on fish growth and epidermal sensory cells: 13th International Conference of Fish and Shellfish Diseases, Grado, Italy, 2007.

McAdam, S.O., 2011, Effects of substrate condition on habitat use and survival by white sturgeon (Acipenser transmontanus) larvae and potential implications for recruitment: Canadian Journal of Fisheries and Aquatic Sciences, v. 68, no. 5, p. 812-822, [Also available at http://dx.doi.org/10.1139/f2011-021].

McAdam, S.O., 2012, Diagnosing causes of white sturgeon (Acipenser transmontanus) recruitment failure and the importance of substrate condition to yolksac larvae survival: Vancouver, B.C., Canada, University of British Columbia, Ph.D. dissertation, 175 p.

McElroy, B., DeLonay, A., and Jacobson, R., 2012, Optimum swimming pathways of fish spawning migration in rivers: Ecology, v. 93, no. 1, p. 29-34, [Also available at http://dx.doi.org/10.1890/11-1082.1].

Morris, D.M., Gemeinhardt, T.R., Gosch, N.J.C., and Jensen, D.E., 2013, Water quality during two high-flow years on the Lower Missouri River: The effects of reservoir and tributary contributions: River Research and Applications, v. 30, no. 8, p. 1024-1033, [Also available at http://dx.doi.org/10.1002/Rra.2693].

Morrow, J.V., Kirk, J.P., Killgore, K.J., and George, S.G., 1998, Age, Growth, and Mortality of Shovelnose Sturgeon in the Lower Mississippi River: North American Journal of Fisheries Management, v. 18, no. 3, p. 725-730, [Also available at http://www.tandfonline.com/doi/abs/10.1577/15488675\%281998\%29018\%3C0725\%3AAGAMOS\%3E2.0.CO\%3B2]. 
Murphy, D.D., and Weiland, P.S., 2011, The route to best science in implementation of the Endangered Species Act's consultation mandate: The benefits of structured effects analysis: Environmental Management, v. 47, no. 2, p. 161-172, [Also available at http://www.ncbi.nlm.nih.gov/pubmed/21161526].

Nelson, L.R., and Small, B.C., 2014, Stress response in pallid sturgeon following three stimulated hatchery stressors: North American Journal of Aquaculture, v. 76, no. 2, p. 170-177, [Also available at http://dx.doi.org/10.1080/15222055.2014.886651].

Oldenburg, E.W., 2008, Effects of acclimation on poststocking dispersal of age-1 pallid sturgeon: Bozeman, Mont., Montana State University, M.S. thesis, 54 p.

Oldenburg, E.W., Guy, C.S., Cureton, E.S., Webb, M.A.H., and Gardner, W.M., 2011, Effects of acclimation on poststocking dispersal and physiological condition of age-1 pallid sturgeon: Journal of Applied Ichthyology, v. 27, no. 2, p. 436-443, [Also available at http://dx.doi.org/10.1111/j.1439-0426.2010.01651.x].

Papanicolaou, A.N.T., Elhakeem, M., Dermisis, D., and Young, N., 2011, Evaluation of the Missouri River shallow water habitat using a 2D-hydrodynamic model: River Research and Applications, v. 27, no. 2, p. 157-167, [Also available at http://dx.doi.org/10.1002/rra.1344].

Papoulias, D.M., DeLonay, A.J., Annis, M.L., Wildhaber, M.L., and Tillitt, D.E., 2011, Characterization of environmental cues for initiation of reproductive cycling and spawning in shovelnose sturgeon (Scaphirhynchus platorynchus) in the Lower Missouri River, U.S.A.: Journal of Applied Ichthyology, v. 27, no. 2, p. 335-342, [Also available at http://dx.doi.org/10.1111/j.1439-0426.2010.01657.x].

Papoulias, D.M., M.L., A., DeLonay, A.J., and Tillitt, D.E., 2007, Reproductive physiology of Missouri River gravid pallid sturgeon and shovelnose sturgeon during the 2005 and 2006 spawning seasons, chap. of Korschgen, C.E., Factors affecting the reproduction, recruitment, habitat, and population dynamics of Pallid Sturgeon and Shovelnose Sturgeon in the Missouri River, U.S. Geological Survey Open-File Report 2007-1262, p. 107-136.

Parsley, M.J., Anders, P.J., Miller, A.I., Beckman, L.G., and McCabie, G.T., Jr., 2002, Recovery of white sturgeon populations through natural production: Understanding the influence of abiotic and biotic factors on spawning and subsequent recruitment: American Fisheries Society Symposium, v. 28, p. 55-66.

Peters, E.J., and Parham, J.E., 2007, Ecology and management of sturgeon in the Lower Platte River: Nebraska Game and Parks Commission, 208 p.

Phelps, Q.E., Tripp, S.J., Hintz, W.D., Garvey, J.E., Herzog, D.P., Ostendorf, D.E., Ridings, J.W., Crites, J.W., and Hrabik, R.A., 2010, Water temperature and river stage influence mortality and abundance of naturally occurring Mississippi River Scaphirhynchus sturgeon: North American Journal of Fisheries Management, v. 30, no. 3, p. 767-775, [Also available at http://dx.doi.org/10.1577/m09-176.1].

Phelps, Quinton E., Whitledge, Gregory W., Tripp, Sara J., Smith, Kurt T., Garvey, James E., Herzog, David P., Ostendorf, David E., Ridings, Joseph W., Crites, Jason W., Hrabik, Robert A., Doyle, Wyatt J., Hill, Tracy D., and Trudel, M., 2012, Identifying river of origin for age-0 Scaphirhynchus sturgeons in the Missouri and Mississippi Rivers using fin ray microchemistry: Canadian Journal of Fisheries and Aquatic Sciences, v. 69, no. 5, p. 930-941, [Also available at http://dx.doi.org/10.1139/f2012-038]. 
Quist, M.C., Boelter, A.M., Lovato, J.M., Korfanta, N.M., Bergman, H.L., Latka, D.C., Korschgen, C.E., Galat, D.L., Krentz, S., Oetker, M., Olson, M., Scott, C.M., and Berkley, J., 2004, Research and assessment needs for pallid sturgeon recovery in the Missouri River: Laramine, Wyo., 2004, U.S. Geological Survey, U.S. Army Corps of Engineers, U.S. Fish and Wildlife Service, U.S. Environmental Protection Agency, William D. Ruckelshaus Institute of Environment and Natural Resources, 96 p.

Quist, M.C., Guy, C.S., Pegg, M.A., Braaten, P.J., Pierce, C.L., and Travnichek, V.H., 2002, Potential influence of harvest on shovelnose sturgeon populations in the Missouri River system: North American Journal of Fisheries Management, v. 22, no. 2, p. 537-549, [Also available at http://dx.doi.org/10.1577/1548-8675(2002)022<0537:Piohos>2.0.Co;2].

Reed, B.C., and Dean, J.C., 2005, Population abundance and size characteristics of pallid sturgeon from the Old River Control Complex, Louisiana: Scaphirhynchus Conference: Alabama, pallid, and shovelnose sturgeon, St. Louis, 2005.

Reuter, J.M., Jacobson, R.B., Elliott, C.M., and DeLonay, A., 2009, Assessment of Lower Missouri River physical aquatic habitat and its use by adult sturgeon (Genus Scaphirhynchus), 2005-07: U.S. Geological Survey Scientific Investigations Report 2009-5121, 81 p.

Reuter, J.M., Jacobson, R.B., Elliott, C.M., Johnson, H.E., and Delonay, A.J., 2008, Hydraulic and substrate maps of reaches used by sturgeon (Genus Scaphirhynchus) in the Lower Missouri River, 2005-07: U.S. Geological Survey Data Series 386, 442 p.

Reynolds, S., and Tyre, A.J., 2011a, A life history model for pallid sturgeon: University of Nebraska.

Reynolds, S., and Tyre, A.J., 2011b, A life history model for pallid sturgeon: University of NebraskaLincoln.

Ridenour, C.J., Doyle, W.J., and Hill, T.D., 2011a, Habitat assessment and monitoring program 2010 pilot study: A comparison of HAMP bends to "end state" habitats: Columbia, Mo., U.S. Fish and Wildlife Service, 17 p.

Ridenour, C.J., Doyle, W.J., and Hill, T.D., 2011b, Habitats of age-0 sturgeon in the Lower Missouri River: Transactions of the American Fisheries Society, v. 140, no. 5, p. 1351-1358, [Also available at $h t t p: / / d x . d o i . o r g / 10.1080 / 00028487.2011 .620493]$.

Ridenour, C.J., Starostka, A.B., Doyle, W.J., and Hill, T.D., 2009, Habitat used by Macrhybopsis chubs associated with channel modifying structures in a large regulated river: Implications for river modification: River Research and Applications, v. 25, no. 4, p. 472-485, [Also available at http://dx.doi.org/10.1002/Rra.1175].

Rotella, J., 2012, Upper basin pallid sturgeon survival estimation project: Upper basin pallid sturgeon work group 2010 update, 46 p.

Sampson, S.J., and Hall, J.R., 2011, Habitat assessment and monitoring program: Macroinvertebrate community assessment of constructed backwaters and side channels of the channelized Missouri River: Nebraska Game and Parks Commission, 26 p.

Schapaugh, A., Hiller, T.L., and Tyre, A.J., 2010, The pallid sturgeon habitat assessment and monitoring program 2007-2009: University of Nebraska, Lincoln, 29 p.

Schapaugh, A.W., and Tyre, A.J., 2011, Power analysis for the Pallid Sturgeon Population Assessment Program: University of Nebraska - Lincoln, 42 p.

Schloesser, J.T., Paukert, C.P., Doyle, W.J., Hill, T.D., Steffensen, K.D., and Travnichek, V.H., 2012, Fish assemblages at engineered and natural channel structures in the Lower Missouri River: Implications for modified dike structures: River Research and Applications, v. 28, no. 10, p. 1695-1707, [Also available at http://dx.doi.org/10.1002/Rra.1578]. 
Schrey, A.W., 2007, Discriminating pallid sturgeon (Scaphirhynchus albus) and shovelnose sturgeon (S. platorhynchus) and intraspecific geographic variation based on genetic and morphological characters: Carbondale, Ill., Southern Illinois University, Ph.D. dissertation, 222 p.

Schrey, A.W., Boley, R., and Heist, E.J., 2011, Hybridization between pallid sturgeon (Scaphirhynchus albus) and shovelnose sturgeon (Scaphirhynchus platorynchus): Journal of Fish Biology, v. 79, no. 7, p. 1828-1850, [Also available at http://www.ncbi.nlm.nih.gov/pubmed/22141890].

Schrey, A.W., and Heist, E.J., 2007, Stock structure of pallid sturgeon analyzed with microsatellite loci: Journal of Applied Ichthyology, v. 23, no. 4, p. 297-303, [Also available at http://dx.doi.org/10.1111/j.1439-0426.2007.00881.x].

Sechler, D.R., 2010, Effect of abiotic and biotic factors on diet composition of age-0 sturgeon (Scaphirhychus spp.) in the middle Mississippi River: Carbondale, Ill., Southern Illinois University, M.S. thesis, 79 p., [Also available at http://fishdata.siu.edu/sechler.pdf].

Sechler, D.R., Phelps, Q.E., Tripp, S.J., Garvey, J.E., Herzog, D.P., Ostendorf, D.E., Ridings, J.W., Crites, J.W., and Hrabik, R.A., 2012, Habitat for age-0 shovelnose sturgeon and pallid sturgeon in a large river: Interactions among abiotic factors, food, and energy intake: North American Journal of Fisheries Management, v. 32, no. 1, p. 24-31, [Also available at http://dx.doi.org/10.1080/02755947.2012.655848].

Sechler, D.R., Phelps, Q.E., Tripp, S.J., Garvey, J.E., Herzog, D.P., Ostendorf, D.E., Ridings, J.W., Crites, J.W., and Hrabik, R.A., 2013, Effects of river stage height and water temperature on diet composition of year-0 sturgeon (Scaphirhynchus spp.) —a multi-year study: Journal of Applied Ichthyology, v. 29, no. 1, p. 44-50, [Also available at http://dx.doi.org/10.1111/Jai.12047].

Shuman, D.A., Klumb, R.A., Wilson, R.H., Jaeger, M.E., Haddix, T., Gardner, W.M., Doyle, W.J., Horner, P.T., Ruggles, M., Steffensen, K.D., Stukel, S., and Wanner, G.A., 2011, Pallid sturgeon size structure, condition, and growth in the Missouri River Basin: Journal of Applied Ichthyology, v. 27, no. 2, p. 269-281, [Also available at http://dx.doi.org/10.1111/j.14390426.2010.01645.x].

Shuman, D.A., Willis, D.W., and Krentz, S.C., 2006, Application of a length-categorization system for pallid sturgeon (Scaphirhynchus albus): Journal of Freshwater Ecology, v. 21, no. 1, p. 71-76, [Also available at $h t t p: / / d x . d o i . o r g / 10.1080 / 02705060.2006 .9664098]$.

Snook, V.A., Peters, E.J., and Young, L., 2002, Movements and habitat use by hatchery reared pallid sturgeon in the Lower Platte River, Nebraska, chap. of van Winkle, W., Anders, P.J., Secor, D.H., and Dixon, D.A., Biology, management, and protection of North American sturgeon: Bethesda, Md., American Fisheries Society, p. 161-174.

Steffensen, K.D., Pegg, M.A., and Mestl, G., 2013a, Population prediction and viability model for pallid sturgeon (Scaphirhynchus albus (Forbes and Richardson)) in the Lower Missouri River: Journal of Applied Ichthyology, v. 29, no. 5, p. 984-989, [Also available at http://dx.doi.org/10.1111/jai.12277].

Steffensen, K.D., Pegg, M.A., and Mestl, G., 2013b, Population prediction and viability model for pallid sturgeon (Scaphirhynchus albus, Forbes and Richardson, 1905) in the lower Missouri River: Journal of Applied Ichthyology, v. 29, no. 5, p. 984-989.

Steffensen, K.D., Pegg, M.A., and Mestl, G.E., 2013c, Population characteristics of pallid sturgeon (Scaphirhynchus albus (Forbes \& Richardson)) in the Lower Missouri River: Journal of Applied Ichthyology, v. 29, no. 4, p. 687-695, [Also available at http://dx.doi.org/10.1111/jai.12196].

Steffensen, K.D., Powell, L.A., and Pegg, M.A., 2012, Population size of hatchery-reared and wild pallid sturgeon in the Lower Missouri River: North American Journal of Fisheries Management, v. 32, no. 1, p. 159-166, [Also available at http://dx.doi.org/10.1080/02755947.2012.661388]. 
Sustainable Ecosystems Institute, 2004, Independent science review of the pallid sturgeon assessment program: Final report: Sustainable Ecosystems Institute, 76 p.

Sustainable Ecosystems Institute, 2005, Independent science review of the habitat assessment and monitoring program study plan for the Missouri River: Sustainable Ecosystems Institute, 39 p.

Sustainable Ecosystems Institute, 2007, Independent science review of the models and linkages for hydrological and biological processes of the Missouri River: Sustainable Ecosystems Institute, $23 \mathrm{p}$.

Sustainable Ecosystems Institute, 2008, Review of comprehensive sturgeon research program: Sustainable Ecosystems Institute, 49 p.

Swigle, B.D., 2003, Movements and habitat use by shovelnose and pallid sturgeon in the Lower Platte River, Nebraska: Lincoln, Nebr., University of Nebraska, M.S. thesis, 137 p.

Tranah, G., Campton, D.E., and May, B., 2004, Genetic evidence for hybridization of pallid and shovelnose sturgeon: Journal of Heredity, v. 95, no. 6, p. 474-480, [Also available at http://www.ncbi.nlm.nih.gov/pubmed/15475392].

Tranah, G.J., Kincaid, H.L., Krueger, C.C., Campton, D.E., and May, B., 2001, Reproductive isolation in sympatric populations of pallid and shovelnose sturgeon: North American Journal of Fisheries Management, v. 21, no. 2, p. 367-373, [Also available at $h t t p: / / d x . d o i . o r g / 10.1577 / 1548$ 8675(2001)021<0367:Riispo>2.0.Co;2].

U.S. Army Corps of Engineers, 2004, Summary Missouri River final environmental impact statement: Master water control manual review and update: U.S. Army Corps of Engineers, Northwestern Division, 28 p.

U.S. Army Corps of Engineers, 2006, Missouri River Mainstem Reservoir System: Master Water Control Manual, Missouri River Basin: U.S. Army Corps of Engineers, Northwest Division, 431 p.

U.S. Environmental Protection Agency, 2011, STORET, Available at: http://www.epa.gov/storet/ Date accessed: 2011.

U.S. Fish and Wildlife Service, 2000, Biological opinion on the operation of the Missouri River main stem reservoir system, operation and maintenance of the Missouri River bank stabilization and navigation project, and operation of the Kansas River reservoir system: U.S. Fish and Wildlife Service, $296 \mathrm{p}$.

U.S. Fish and Wildlife Service, 2003, Amendment to the 2000 biological opinion on the operation of the Missouri River main stem reservoir system, operation and maintenance of the Missouri River bank stabilization and navigation project, and operation of the Kansas River reservoir system: U.S. Army Corps of Engineers, 12 p.

U.S. Fish and Wildlife Service, 2008, Pallid sturgeon (Scaphirhynchus albus) range-wide stocking and augmentation plan: U.S. Fish and Wildlife Service, 55 p.

U.S. Fish and Wildlife Service, 2011, Environmental Contaminants Data Management System (ECDMS), http://www.fws.gov/chemistry/acf_ecdms.html Date accessed: 2011.

U.S. Fish and Wildlife Service, 2012, Biological procedures and protocols for researchers and managers handling pallid sturgeon: U.S. Fish and Wildlife Service, 40 p.

U.S. Fish and Wildlife Service, 2014, Revised recovery plan for the pallid sturgeon (Scaphirhynchus albus): U.S. Fish and Wildlife Service, 115 p.

U.S. Geological Survey, 1995, Biomonitoring of Environmental Status and Trends (BEST), Available at: http://www.cerc.usgs.gov/data/best/search/ Date accessed: 2011.

U.S. Geological Survey, 2011a, National Water Information System, Available at: htt://waterdata.usgs.gov/nwis Date accessed: 2011. 
U.S. Geological Survey, 2011b, Sediment-Contaminant Database for the Upper Mississippi River System and Selected Tributaries, Available at:

http://www.umesc.usgs.gov/data_library/sediment_contaminants/sediment_contaminant_page.ht ml Date accessed: 2011.

Walters, C.J., and Collie, J.S., 1988, Is research on environmental factors useful to fisheries management?: Canadian Journal of Fisheries and Aquatic Sciences, v. 45, no. 10, p. 1848-1854, [Also available at $h t t p: / / d x . d o i . o r g / 10.1139 / F 88-217]$.

Wanner, G.A., 2006, Sampling techniques for juvenile pallid sturgeon and the condition and food habits of sturgeon in the Missouri River below Fort Randall Dam, South Dakota: Brookings, S. Dak., South Dakota State University, Master of Science, 175 p., [Also available at http://pubstorage.sdstate.edu/wfs/thesis/Wanner-Greg-A-MS-2006.pdf].

Wanner, G.A., Shuman, D.A., and Willis, D.W., 2007, Food habits of juvenile pallid sturgeon and adult shovelnose sturgeon in the Missouri River downstream of Fort Randall Dam, South Dakota: Journal of Freshwater Ecology, v. 22, no. 1, p. 81-92, [Also available at http://dx.doi.org/10.1080/02705060.2007.9664148].

Welker, T.L., and Drobish, M.R., 2012a, Missouri River standard operating procedures for fish sampling and data collection: U.S. Army Corps of Engineers, 214 p.

Welker, T.L., and Drobish, M.R., 2012b, Pallid sturgeon population assessment project, guiding document: U.S. Army Corps of Engineers, 24 p.

Wildhaber, M.L., Wikle, C.K., Moran, E.H., Anderson, C.J., Franz, K.J., and Dey, R., 2015a, Hierarchical stochastic modelling of large river ecosystems and fish growth across spatiotemporal scales and climate models: the Missouri River endangered pallid sturgeon example: Geological Society, London, Special Publications, v. 408. [Also available at http://dx.doi.org/10.1144/sp408.11].

Wildhaber, M.L., Albers, J.L., Green, N.S., and Moran, E.H., 2015b, A fully-stochasticized, agestructured population model for population viability analysis of fish: Lower Missouri River endangered pallid sturgeon example: Ecological Modelling, [Also available at http://dx.doi.org/10.1016/j.ecolmodel.2015.07.019].

Wildhaber, M.L., DeLonay, A.J., Papoulias, D.M., Galat, D.L., Jacobson, R.B., Simpkins, D.G., Braaten, P.J., Korschgen, C.E., and Mac, M.J., 2011a, Identifying structural elements needed for development of a predictive life-history model for pallid and shovelnose sturgeons: Journal of Applied Ichthyology, v. 27, no. 2, p. 462-469, [Also available at http://dx.doi.org/10.1111/j.1439-0426.2011.01731.x].

Wildhaber, M.L., Holan, S.H., Bryan, J.L., Gladish, D.W., and Ellersieck, M., 2011b, Assessing power of large river fish monitoring programs to detect population changes: The Missouri River sturgeon example: Journal of Applied Ichthyology, v. 27, no. 2, p. 282-290, [Also available at http://dx.doi.org/10.1111/j.1439-0426.2010.01635.x].

Wildhaber, M.L., Holan, S.H., Davis, G.M., Gladish, D.W., DeLonay, A.J., Papoulias, D.M., and Sommerhauser, D.K., 2011c, Evaluating spawning migration patterns and predicting spawning success of shovelnose sturgeon in the Lower Missouri River: Journal of Applied Ichthyology, v. 27, no. 2, p. 301-308, [Also available at http://dx.doi.org/10.1111/j.1439-0426.2010.01663.x] .

Wildhaber, M.L., Yang, W.H., and Arab, A., 2015b, Population trends, bend use relative to available habitat and within-river-bend habitat use of eight indicator species of missouri and lower Kansas river benthic fishes: 15 years after baseline assessment: River Research and Applications, [Also available at http://dx.doi.org/10.1002/rra.2846]. 
Winders, K.R., and Steffensen, K.D., 2014, Population size of pallid sturgeon, Scaphirhynchus albus (Forbes \& Richardson, 1905), in the Lower Missouri River near Kansas City, Missouri, U.S.A.: Journal of Applied Ichthyology, v. 30, no. 6, p. 1356-1361, [Also available at http://dx.doi.org/10.1111/jai.12558]. 


\section{Appendix A. The Effects of Missouri River Basin Contaminants on Scaphirhynchus Sturgeon-A Summary of Current Research and Future Research Needs.}

\section{Introduction}

As long lived piscivores, pallid sturgeon face the potential that contaminants are bioaccumulating in their tissues and thereby contributing to their documented lack of recruitment. This concern has led to the general hypothesis that contaminants are an important factor in their decline within the Missouri River Basin. Unfortunately, data supporting or refuting this hypothesis are limited. Few wild pallid sturgeon specimens have been available for chemical or biochemical analyses and only recently have hatchery or captive individuals been available for experimental exposures. Moreover, adverse effects in individual Scaphirhynchus albus (pallid sturgeon) populations are not well understood because of the lack of data. This appendix summarizes what is known about contaminant effects in pallid sturgeon; this appendix is based on a more comprehensive report in preparation by the U.S. Fish and Wildlife Service (M. Webb, written, commun., 2014).

A variety of contaminants have been measured in Missouri River sturgeon tissues. Among them are both naturally occurring elements and mining by-products (copper, iron, selenium, cadmium and mercury); polybrominated diphenyl ethers (PBDEs) (flame retardants); persistent organochlorine pollutants (POPs) that are currently banned in the United States, which include polychlorinated biphenyls (PCBs, formerly used in industry), chlordane and dichlorodiphenyltrichloroethane (DDT, pesticides) (Ruelle and Keenlyne, 1993; Coffey and others, 2000; Schwarz and others, 2006; Buckler, 2011). These contaminants as well as unregulated chemicals associated with municipal wastewater (endocrine disruptors, pharmaceuticals, and surfactants) are known to adversely affect fish health and reproduction (Jarvinen and Ankley, 1999; Giesy and others, 2000; Hemmer and others, 2001; Metcalfe and others, 2001; Kidd and others, 2007; Tillitt and others, 2010; Papoulias and others, 2014). Effects of these types of contaminants on Scaphirhynchus sturgeon are largely unknown.

\section{Historical Information}

In 1993, Keenlyne and Ruelle published the only known study in which contaminant concentrations were analyzed in wild pallid sturgeon. Three individual pallid sturgeon in this study were from the Missouri River. Several contaminants were reported above Food and Drug Administration (FDA) concentrations for human consumption including PCBs [1.18-28.52 mg/kg wet weight (ww)], and mercury (maximum $16.00 \mathrm{mg} / \mathrm{kg} \mathrm{ww}$ ). Additional contaminants of concern including DDT metabolites (0.06-3.78 mg/kg ww), and selenium (maximum $7.66 \mathrm{mg} / \mathrm{kg} \mathrm{ww}$ ) were also measured. Reductions have been seen in some potentially harmful contaminants in recent decades. Levels of some banned POPs including PCBs, chlordanes, and DDTs have been reduced (Schmitt and others, 1990; Schwarz and others, 2006) and tighter regulations on mining and industry by-products have helped reduce levels of heavy metals (Schmitt and Brumbaugh, 1990). Such reductions are positive, but questions about current contaminant levels and their effects on fish remain. Research on effects on sturgeon from endocrine-disrupting chemicals, such as pharmaceuticals (ethyl estradiol, and surfactants), agricultural products (fertilizers, pest controls such as atrazine), and PBDEs (flame retardants), which are believed to be in the Missouri River, are lacking. 


\section{Persistent Organocholorine Pollutants Exposure and Effects}

The persistent POPs, as well as 2,3,7,8-tetrachlorodibenzo-p-dioxins (TCDDs), chlordane, and mercury are regularly detected in the sampling of shovelnose sturgeon tissues as part of the state departments of health monitoring of contaminant levels in edible fishes in the Missouri River Basin (U.S. Environmental Protection Agency, 2014). These chemicals including PCBs, TCDD, and organochlorine pesticides, notably chlordane and DDT, although no longer in used in the United States, are found in the environment (Jones and de Voogt, 1999). Nevertheless, data show that tissue contaminant concentrations have continued to decline. These trends are consistent with trends nationwide, not only for fish tissue concentrations, but also for riverine sediments (Schmitt and others, 1990; Schwarz and others, 2006).

The early-life stage in fish is among the most sensitive to contaminant exposure (Walker and Peterson, 1991; Di Giulio and Tillitt, 1999). Environmentally persistent contaminants including PCBs, TCDD, PBDE and chlordane are often found to bioaccumulate in gonadal tissues such that they can be transferred from parent to offspring and thereby expose early-life stages (Miller, 1993; Ungerer and Thomas, 1996; Russell and others, 1999; Serrano and others, 2008). Limited information exists from laboratory studies about the effects of contaminants on early Scaphirhynchus spp. life stages; however, and even less is known about exposure levels in offspring of wild-caught parents. Dioxin (for example, TCDD) (Safe, 1994; Van den Berg and others, 1998) and dioxin-like chemicals (for example, 3,3',4,4',5-pentachlorobiphenyl or PCB-126) (Bhavsar and others, 2007) are some of the most potent of the POPs in the Missouri River and elsewhere.

Tillitt and others (2004) and Buckler (2011) evaluated the sensitivity of early-life stage Scaphirhynchus sturgeon to chlordane, PCB-126, and TCDD by exposing newly-spawned eggs to variable concentrations of these chemicals in a water bath to determine the lethal dose at which 50 percent of the fish would die $\left(\mathrm{LD}_{50}\right)$. Increased pathologies (craniofacial/spinal deformities, edemas, tubular hearts, delayed development, and hemorrhaging) and mortality was observed with increasing contaminant levels in these studies. Hatch rates were consistently high across doses for PCB- 126 and TCDD but in chlordane studies, egg quality was generally poor. Shovelnose sturgeon $\mathrm{LD}_{50}$ was calculated to be $92.1 \mu \mathrm{g}$ chlordane per gram of egg (chlordane/g egg). Pallid sturgeon $\mathrm{LD}_{50}$ was found to be similar to shovelnose with PCB-126 having an LD Lo $_{50} 159$ nanograms per gram (ng/g) and TCDD an $\mathrm{LD}_{50} 12 \mathrm{ng} / \mathrm{g}$. The study authors concluded that Scaphirhynchus spp. are relatively insensitive to these potent compounds with the LD50 for pallid sturgeon 5 times higher for PCB-126 and 100 times higher for TCDD than the most sensitive of fish species (Buckler, 2011). Moreover, the $\mathrm{LD}_{50 \mathrm{~s}}$ for TCDD and PCB-126 in these studies are much greater than have been or are likely to be found in the Missouri River. The greatest total PCBs reported are 6,000 ng/g egg (Buchanan and others, 2000). Total PCB measurements include the less potent PCB congeners, and, therefore, an estimated 500,000 total PCB ng/g egg would be required to result in the mortality and effects similar to the PCB-126 and TCDD effects reported by Buckler (2011).

In addition to determining the $\mathrm{LD}_{50}$ of these chemicals for Scaphirhynchus, Buckler (2011) evaluated some characteristics of wild-caught Scaphirhynchus reproduction and offspring success. Buckler collected reproductive shovelnose from a reference site on the Mississippi River (Saverton, Mo.) and an area of historically high POPs contamination and tissue concentrations (Cape Girardeau, Mo.). These fish were artificially spawned following general hatchery techniques and the resulting eggs and free embryos were analyzed for fitness relative to the corresponding maternal contaminant loads. Fertilization rates were similar for both sites and unaffected by the contaminant levels of the parent. A decrease in hatch and mortality between 2 and 5 days post fertilization was associated with increased POPs concentrations. Embryos from Cape Girardeau spawns had significantly greater mortality (10-28 
percent prior to hatch) than those of Saverton beginning soon after fertilization. However, considerable mortality was observed in offspring from both the reference and contaminated sites suggesting culture conditions may have been a factor in the elevated mortality, and, therefore, may have affected results. These results are inconsistent with other portions of Buckler's (2011) research in which water-bath exposures of the most potent PCB congeners and TCDD did not affect hatch and mortalities did not occur until after hatch. This may suggest that the mixture of contaminants associated with the Cape Girardeau site contributed to the mortality either directly or in combination with poor culture conditions and caused greater mortalities before hatching. In older post-hatch free embryos, mortality was not substantially different between sites and did not increase with contaminant levels; these results are also contrary to Buckler's research (2011) with PCB-126 and TCDD that showed an increase in mortality after hatch with increasing doses.

Buckler (2011) showed that shovelnose sturgeon from Saverton had a different chemical fingerprint than those from Cape Girardeau. These sites likely had different types and degrees of contamination resulting in the tissue analyses showing different POP congeners at the two sites. Cape Girardeau fish tissues had greater total PCB and other POPs than Saverton fish, and the mixtures were distinct. These findings are similar to Coffey and others (2000) in which shovelnose sturgeon from two Mississippi River sites were found to have distinctly different contaminant profiles. A combination of composition and concentration of contaminants may have contributed to the greater mortality of the Cape Girardeau embryos seen in Buckler's studies. Other chemicals that were not targeted for analysis in Buckler's study, including chemicals associated with municipal wastes (pharmaceuticals and surfactants) and agriculture (atrazine), may also have affected embryo fitness and mortality. These chemicals are largely unregulated and have been shown to cause reproductive impairments in other fish species (Tillitt and others, 2010; Papoulias and others, 2014). Additional research is needed to clarify the effects seen in both portions of this study and to validate the effects concentrations and contaminant mixtures have on Scaphirhynchus.

\section{Atrazine and Selenium Effects}

Studies of the effects of atrazine and selenium (Se) are the only other Scaphirhynchus early-life stage chemical exposure experiments known. Elevated levels of atrazine (in blood) and selenium (in muscle) have been found in shovelnose sturgeon from the Platte River (3.2-9.3 $\mu \mathrm{g} / \mathrm{g}$ dry weight [dw]) (Schwarz and others, 2006). Atrazine is the second most heavily used agricultural herbicide in the United States and concentrations shown to cause effects in fish are commonly documented in the Missouri watershed (Kiely and others, 2004). Nevertheless, in experiments at USGS Columbia Environmental Research Center, pallid and shovelnose sturgeon early-life stage mortality or gross deformities were not affected by water bath exposure to atrazine at levels up to $50 \mu \mathrm{g} / \mathrm{L}$ (D. Papoulias oral commun., 2014)

Selenium is an important elemental micronutrient but can cause harm to fish at elevated levels (Besser and others, 2012). To evaluate if environmental levels of selenium are diminishing recruitment of Scaphirhynchus in the Platte River, Papoulias and others (2010) mimicked maternal loading of selenium in eggs by microinjecting clean fertilized Scaphirhynchus eggs with the biologically active form of selenium. Similar $\mathrm{LD}_{50} \mathrm{~s}$ were determined for shovelnose and pallid sturgeon - $17.5 \mu \mathrm{g}$ of selenium per gram per egg and $16.5 \mu$ g selenium per gram per egg, respectfully. Increased mortality and gross pathologies (craniofacial/spinal deformities, erythrocyte abnormalities, and edemas) were found with increasing concentrations of selenium. However, both the $\mathrm{LD}_{50}$ and the concentration of selenium at which anomalies were notable are above levels found in the Platte River. 
The early-life stage studies suggest Scaphirhynchus larvae may well tolerate current basin-wide levels of dioxin (PCBs and TCDD), chlordane, atrazine, and selenium (Tillitt and others, 2004; Papoulias and others, 2010; Buckler, 2011). The effects and tolerance of early-life stages of sturgeon to other contaminants and mixtures of contaminants found in the Missouri River are unknown. Current research has not addressed the effects that multiple types of stressors (chemical and physical) may have on Scaphirhynchus young. Additionally, no research has been performed to evaluate the sublethal effects that contaminants may have on the overall fitness of the individual and subsequently the population as a whole.

\section{Reproductive Anomalies}

A small number of studies have investigated the relationship between contaminant exposures and observed reproductive anomalies on shovelnose sturgeon. Intersex is a common gonadal anomaly reported for Missouri River sturgeon. Intersex is the condition in which both male and female gametes are found in the same individual. Intersexed individuals are often primarily male with testicular tissue that contains ova, ranging in size from a few microscopic early-stage ova to large clusters of macroscopic late-stage black ova. The condition can be found throughout the reproductive cycle. This condition is not usually common or normal as sturgeon are gonochronistic and intersex is rare (Van Eenenaam and Dorsohov, 1998). The cause and effects of intersex is unknown. Contaminants including POPs have been suggested as possible causes of the intersex condition. Coffey and others (2000) collected shovelnose sturgeon from a Mississippi River site known to be contaminated with POPs. These authors found two intersexed fish (4.9 percent, 2 of 41), one of which had among the highest concentrations of combined PCBs and chlordanes reported for that survey. Even so, the concentrations were below FDA consumption advisories of $2.0 \mathrm{mg} / \mathrm{kg} \mathrm{ww}$ and $0.3 \mathrm{mg} / \mathrm{kg}$ ww for PCBs and chlordanes, respectively. A male from the Mississippi River site with the highest level of combined total PCBs and chlordanes $(1.683 \mu \mathrm{g} / \mathrm{g} \mathrm{ww})$ did not manifest any abnormalities. In a follow-up study, Harshbarger and others (2000) characterized the intersexed fish and suggested the condition was associated with urbanrunoff contaminants including POPs. Later, Koch and others (2006) found 10.4 percent (5 of 48) of shovelnose sturgeon from the Mississippi River were intersexed. This study showed a correlation between POPs and intersex with increased levels of organochlorides (OCs) in brains of intersex fish. Papoulias and others (2009) performed a similar analysis on shovelnose sturgeon from the Missouri River analyzing the brains and testes of both intersexed and normal males. The findings from their study did not show a correlation of increased POPs and intersex; however, there was a correlation with reduced gonad size. Concentrations of POPs were similar in tissues of both normal and abnormal fish.

Limited data indicate that there may be an increase in reproductive anomalies in sturgeon sampled near municipalities (Coffey and others, 2000). In an unpublished study, male shovelnose sturgeon were collected from the Missouri and Mississippi River (D. Papoulias, oral commun., 2014). Of the 334 fish collected, 12 Missouri River fish (5.7 percent) and one Mississippi River (0.1 percent) fish were macroscopically classified as intersexed. Higher numbers of intersex individuals were found at or just downstream of Kansas City and Columbia, Mo. This trend of increased intersex near municipalities may be due to endocrine disruptors, pharmaceuticals, and other chemicals associated with municipal wastewater-treatment facilities (D. Papoulias, oral commun., 2014). Additional research is needed to validate these trends and their causes.

Reproductive biomarkers indicative of exposure to, or effects of, chemical environmental stressors, especially endocrine disruptors, that have been measured in Scaphirhynchus blood plasma include 17 beta-estradiol (E) testosterone (T), 11-ketotestosterone (KT), and vitellogenin (Vtg). Generally, male E:T ratios are less than 1. Ratios greater than 1 are more similar to female profiles and, 
in males, may indicate exposure to estrogen-mimicking chemicals. Similarly, female E:T ratios less than 1 are generally more like males and may suggest androgenic chemical exposure; however, such ratios must be interpreted carefully because estrogen and androgen levels normally cycle up and down throughout the reproductive life of a fish (Schmitt and others, 2000; Craig and others, 2009). Vitellogenin, a precursor to yolk protein, is generally absent in male and juvenile fish, but has been found to be elevated in fish blood plasma in areas with endocrine disrupting chemicals (Goodbred and others, 1997). Normal Scaphirhynchus sturgeon hormone and Vtg baseline data have been reported for some populations; however, there may be regional differences among populations (Stahl, 2004; Wildhaber and others, 2005).

Coffey and others (2000) collected two males without gonadal abnormalities from Chester, Ill.; these fish had elevated E:T ratios and Vtg concentrations, and also had elevated total PCBs and chlordane concentrations. Of the intersex individuals they collected from the Mississippi River, one had elevated E:T ratios but neither had detectable amounts of Vtg. Three males from the reference site had detectible, but low, vitellogenin. All male Vtg levels reported in this study were much lower (fiftyfold to one hundredfold) than those reported for females. It is not unusual for males of some fish species to produce some Vtg without any exposure to contaminants (Goodwin and others, 1992).

Schwarz and others (2006) also reported unusual E:T ratios and Vtg in male shovelnose sturgeon from the Platte River. In this study, nearly half the males and females had unusual E:T ratios with male ratios greater than one and female ratios less than one. Additionally, 23 of 33 male shovelnose sturgeon had concentrations of Vtg greater than $0.1 \mathrm{mg} / \mathrm{ml}(0.007-2.152 \mathrm{mg} / \mathrm{ml})$. These levels were only slightly less than those reported for females. Schwarz and others (2006) suggest these elevated levels of shovelnose sturgeon male Vtg may, in part, be due to the Vtg analysis, which was not optimized for shovelnose sturgeon. Craig and others (2009) were similarly uncertain of their Vtg results when they attempted to quantify Vtg levels in lake sturgeon using assays established for white and shovelnose sturgeon. Shovelnose sturgeon in this study had lower levels of POPs than reported elsewhere except atrazine, a known endocrine disruptor in some fish (Tillitt and others, 2010; Papoulias and others, 2014), was found in all blood samples ranging from 0.24 to $28 \mu \mathrm{g} / \mathrm{L}$. Additional anomalies included one intersexed individual (2 percent, 1 out of 51) and a high incidence of atresia. Atresia is the degeneration and resorption of ova within the ovary. Atresia in fish is attributed to a variety of stressors including age, water temperature, nutrition, hormone fluctuations, and environmental contaminants including atrazine (Guraya, 1986; Webb and others, 1999; Spanò and others, 2004). Schwarz and others (2006) noted above-normal water temperatures that may have contributed to the elevated levels of atresia reported. Among 337 shovelnose sturgeon in the Missouri River, 7 percent of which were intersexed, the Vtg and hormone biomarkers did not differ between intersexed and non-intersexed fish (Papoulias and others, 2009).

In sum, current research does not clearly establish a link between sturgeon intersex or reproductive biomarkers and contaminant exposure. Additional research is needed to establish cause and reproductive effects. Multiple stressors, both chemical and physical, likely contribute to reproductive anomalies. Numerous explanations for the increased incidence of intersex have been suggested for other fish species, including senescence, genetic abnormalities, radiation, diet, temperature changes, and hybridization (Atz, 1964; Lam, 1983). As a result, the effect that intersex has on the reproduction of an individual and, ultimately, on a population is subject to substantial uncertainty.

\section{Summary}

Contaminants research on Scaphirhynchus sturgeons is limited. Many questions regarding the effects of contaminants on pallid sturgeon and the recruitment of young sturgeon remain. Additional 
research is needed to better evaluate the type of contaminants and contaminant combinations currently in the Missouri River and the effects these contaminants have on Scaphirhynchus. Currently, no direct link has been made between contaminants and the lack of recruitment in pallid sturgeon from the Missouri River. Moreover, although interactions between chemical and physical stressors are likely, there has been no research to evaluate the results of multiple stressors on fitness, reproduction, and recruitment of pallid sturgeon. Ultimately, an understanding of the role contaminants play in sturgeon health, reproduction, and survival may inform specific management practices by identifying sources of stress or by indicating areas to avoid during broodstock sampling or supplemental stocking releases. 


\section{References Cited}

Atz, J.W., 1964, Intersexuality in fishes, chap. of Armstrong, C.N., and Marshall, A.J., Intersexuality in Vertebrates Including Man: London, Academic Press, p. 145-232.

Besser, J.M., Brumbaugh, W.G., Papoulias, D.M., Ivey, C.D., Kunz, J.L., Annis, M.L., and Ingersoll, C.G., 2012, Bioaccumulations and toxicity of selenium during a life-cycle exposure with desert pupfish (Cyprinodon macularius): U.S. Geological Survey Scientific Investigations Report 20125033, 30 p., [Also available at http://pubs.usgs.gov/sir/2012/5033/].

Bhavsar, S.P., Fletcher, R., Hayton, A., Reiner, E.J., and Jackson, D.A., 2007, Composition of dioxinlike PCBs in fish: An application for risk assessment: Environmental Science \& Technology, v. 41, no. 9, p. 3096-3102, [Also available at http://www.ncbi.nlm.nih.gov/pubmed/17539510].

Buchanan, D.L., Sato, T., Peterson, R.E., and Cooke, P.S., 2000, Antiestrogenic effects of 2,3,7,8Tetrachlorodibenzo-p-dioxin in mouse uterus: Critical role of the aryl hydrocarbon receptor in stromal tissue: Toxicological Sciences, v. 57, no. 2, p. 302-311, [Also available at http://dx.doi.org/10.1093/toxsci/57.2.302].

Buckler, J., 2011, Persistent organic pollutant effect on middle Mississippi River Scaphirhynchus sturgeon reproduction and early life stages: Columbia, Mo., University of Missouri, M.S. thesis, 154 p., [Also available at https://mospace.umsystem.edu/xmlui/bitstream/handle/10355/14530/research.pdf?sequence=2].

Coffey, M.J., Phillips, K., Berg, C., Harshbarger, J.C., and Gross, T., 2000, Middle Mississippi River sturgeon health assessment, Illinois, Iowa, and Missouri: U.S. Fish and Wildlife Service Draft Report, 23 p.

Craig, J.M., Papoulias, D.M., Thomas, M.V., Annis, M.L., and Boase, J., 2009, Sex assignment of lake sturgeon (Acipenser fluvescens) based on plasma sex hormone and vitellogenin levels: Journal of Applied Ichthyology, v. 25, p. 60-67, [Also available at http://dx.doi.org/10.1111/j.14390426.2009.01289.x].

Di Giulio, R.T., and Tillitt, D.E., 1999, Reproductive and developmental effects of contaminants in oviparous vertebrates: in Workshop on reproductive and developmental effects of contaminants in oviparous vertebrates, Anaconda, Mont., 1997, Society of Environmental Toxicology and Chemistry, $447 \mathrm{p}$.

Giesy, J.P., Pierens, S.L., Snyder, E.M., Miles-Richardson, S., Kramer, V.J., Snyder, S.A., Nichols, K.M., and Villeneuve, D.A., 2000, Effects of 4-nonylphenol on fecundity and biomarkers of estrogenicity in fathead minnows (Pimephales promelas): Environmental Toxicology and Chemistry, v. 19, no. 5, p. 1368-1377, [Also available at http://dx.doi.org/10.1897/15515028(2000)019<1368:Eonofa>2.3.Co;2].

Goodbred, S.L., Gilliom, R.J., T.S., G., Denslow, N.P., Bryant, W.L., and Schoeb, T.R., 1997, Reconnaissance of 17B estradiol, 11-ketotestosterone, vitellogenin, and gonad histopathology in common carp of United States streams: Potential for contaminant-induced endocrine disruption: U.S. Geological Survey Open -File Report 96-627, 47 p., [Also available at http://water.usgs.gov/nawqa/pnsp/pubs/ofr96-627/].

Goodwin, A.E., Grizzle, J.M., Bradley, J.T., and Estridge, B.H., 1992, Monoclonal antibody-based immunoassay of vitellogenin in the blood of male channel catfish (Ictalurus punctatus): Comparative Biochemistry and Physiology B-Biochemistry \& Molecular Biology, v. 101, no. 3, p. 441-446, [Also available at http://dx.doi.org/10.1016/0305-0491(92)90025-M].

Guraya, S.S., 1986, Monographs in developmental biology: The cell and molecular biology of fish oogenesis: Basel, Switzerland, Karger, 223 p. 
Harshbarger, J.C., Coffey, M.J., and Young, M.Y., 2000, Intersexes in Mississippi River shovelnose sturgeon sampled below Saint Louis, Missouri, U.S.A.: Marine Environmental Research, v. 50, no. 1-5, p. 247-250, [Also available at http://www.ncbi.nlm.nih.gov/pubmed/11460698].

Hemmer, M.J., Hemmer, B.L., Bowman, C.J., Kroll, K.J., Folmar, L.C., Marcovich, D., Hoglund, M.D., and Denslow, N.D., 2001, Effects of p-nonylphenol, methoxychlor, and endosulfan on vitellogenin induction and expression in sheepshead minnow (Cyprinodon variegatus): Environmental Toxicology and Chemistry, v. 20, no. 2, p. 336-343, [Also available at http://dx.doi.org/10.1002/etc.5620200214].

Jarvinen, A.W., and Ankley, G.T., 1999, Linkages to effects to tissue residues: Development of a comprehensive database for aquatic organisms exposed to inorganic and organic chemicals: Society of Environmental Toxicology and Chemistry.

Jones, K.C., and de Voogt, P., 1999, Persistent organic pollutants (POPs): State of the science: Environmental Pollution, v. 100, no. 1-3, p. 209-221, [Also available at http://www.ncbi.nlm.nih.gov/pubmed/15093119].

Kidd, K.A., Blanchfield, P.J., Mills, K.H., Palace, V.P., Evans, R.E., Lazorchak, J.M., and Flick, R.W., 2007, Collapse of a fish population after exposure to a synthetic estrogen: Proceedings of the National Academy of Sciences of the United States of America, v. 104, no. 21, p. 8897-8901, [Also available at http://www.ncbi.nlm.nih.gov/pubmed/17517636].

Kiely, T., Donald, D., and Grube, A., 2004, Pesticides industry sales and usage: 2000 and 2001 Market Estimates: U.S. Environmental Protection Agency Office of Prevention, Pesticides and Toxic Substances, $33 \mathrm{p}$.

Koch, B.T., Garvey, J.E., You, J., and Lydy, M.J., 2006, Elevated organochlorines in the brainhypothalamic-pituitary complex of intersexual shovelnose sturgeon: Environmental Toxicology and Chemistry, v. 25, no. 7, p. 1689-1697, [Also available at http://dx.doi.org/10.1897/05474r.1].

Lam, T.J., 1983, Environmental influences on gonadal activity in fish, chap. of Hoar, W.S., Randall, D.J., and Donaldson, E.M., Fish physiology, Vol 9B: Elsevier, p. 65-116.

Metcalfe, C.D., Metcalfe, T.L., Kiparissis, Y., Koenig, B.G., Khan, C., Hughes, R.J., Croley, T.R., March, R.E., and Potter, T., 2001, Estrogenic potency of chemicals detected in sewage treatment plant effluents as determined by in vivo assays with Japanese medaka (Oryzias latipes): Environmental Toxicology and Chemistry, v. 20, no. 2, p. 297-308, [Also available at http://www.ncbi.nlm.nih.gov/pubmed/11351429].

Miller, M.A., 1993, Maternal transfer of organochlorine compounds in salmonines to their eggs: Canadian Journal of Fisheries and Aquatic Sciences, v. 50, no. 7, p. 1405-1413, [Also available at $h t t p: / / d x . d o i . o r g / 10.1139 / f 93-161]$.

Papoulias, D.M., DeLonay, A., Annis, M.L., Gale, R.W., Wildhaber, M.L., and Tillitt, D.E., 2009, Intersex and other gonadal abnormalities in sturgeon from the Missouri River, USA: in 4th International Workshop on Gonadal Histology, Cadiz, Spain, 2009,p.

Papoulias, D.M., Tillitt, D.E., Annis, M.L., Nicks, D., and Schwarz, M.S., 2010, Laboratory evaluation of effects of early life-stage exposure to selenium on pallid and shovelnose sturgeon: in American Fisheries Society Larval Fish Conference, Pittsburg, 2010,p.

Papoulias, D.M., Tillitt, D.E., Talykina, M.G., Whyte, J.J., and Richter, C.A., 2014, Atrazine reduces reproduction in Japanese medaka (Oryzias latipes): Aquatic Toxicology, v. 154, p. 230-239, [Also available at http://www.ncbi.nlm.nih.gov/pubmed/24929351]. 
Ruelle, R., and Keenlyne, K.D., 1993, Contaminants in Missouri River pallid sturgeon: Bulletin of Environmental Contamination and Toxicology, v. 50, no. 6, p. 898-906, [Also available at http://www.ncbi.nlm.nih.gov/pubmed/8495068].

Russell, R.W., Gobas, F.A.C.P., and Haffner, D.G., 1999, Maternal transfer and in ovo exposure of organochlorines in oviparous organisms: A model and field verification: Environmental Science \& Technology, v. 33, no. 3, p. 416-420, [Also available at http://dx.doi.org/10.1021/Es9800737].

Safe, S.H., 1994, Polychlorinated-biphenyls (PCBs): Environmental-impact, biochemical and toxic responses, and implications for risk assessment: Critical Reviews in Toxicology, v. 24, no. 2, p. 87-149, [Also available at http://dx.doi.org/10.3109/10408449409049308].

Schmitt, C.J., and Brumbaugh, W.G., 1990, National contaminant biomonitoring program: Concentration of arsenic, cadmium, copper, lead, mercury, selenium, and zinc in U.S. freshwater fish, 1976-1984: Archives of Environmental Contamination and Toxicology, v. 19, p. 731-747.

Schmitt, C.J., Dethloff, G.M., Blazer, V.S., Denslow, N.D., Gross, T.S., McDonald, K.K., Tillitt, D.E., and Whyte, J.J., 2000, Biomonitoring of Environmental Status and Trends (BEST) Program: Selected methods for monitoring chemical contaminants and their effects in aquatic ecosystems: U.S. Geological Survey Information Technology Report 2000-0005, 96 p., [Also available at http://www.cerc.usgs.gov/pubs/BEST/methods.pdf].

Schmitt, C.J., Zajicek, J.L., and Peterman, P.H., 1990, National contaminant biomonitoring program: Residues of organochlorine chemicals in U.S. freshwater fish, 1976-1984: Archives of Environmental Contamination and Toxicology, v. 19, no. 5, p. 748-781, [Also available at http://www.ncbi.nlm.nih.gov/pubmed/21318506].

Schwarz, M.S., Lydick, C.D., Tillitt, D.E., Papoulias, D.M., and Gross, T., 2006, A health risk evaluation for pallid sturgeon (Scaphirhychus albus) in the Lower Platte River using shovelnose sturgeon (Scaphirhynchus platorynchus) as a surrogate: U.S. Fish and Wildlife Service, 105 p.

Serrano, R., Blanes, M.A., and Lopez, F.J., 2008, Maternal transfer of organochlorine compounds to oocytes in wild and farmed gilthead sea bream (Sparus aurata): Chemosphere, v. 70, no. 4, p. 561-566, [Also available at http://www.ncbi.nlm.nih.gov/pubmed/17720218].

Spanò, L., Tyler, C.R., van Aerle, R., Devos, P., Mandiki, S.N.M., Silvestre, F., Thomé, J.P., and Kestemont, P., 2004, Effects of atrazine on sex steroid dynamics, plasma vitellogenin concentration and gonad development in adult goldfish (Carassius auratus): Aquatic Toxicology, v. 66, no. 4, p. 369-379, [Also available at http://www.ncbi.nlm.nih.gov/pubmed/15168945].

Stahl, M.T., 2004, Reproductive physiology of shovelnose sturgeon from the middle Mississippi River in relation to seasonal variation in plasma sex steroids, vitellogenin, calcium, and oocyte diameters: Carbondale, Ill., Southern Illinois University, M.S. thesis, 72 p.

Tillitt, D.E., Nicks, D.K., Candrl, J.S., Annis M.L., and Papoulias, D.M., 2004, Determination of the relationship between concentrations of TCDD or chlordane in sturgeon eggs and early life stage development and survival: U.S. Geological Survey FY 2004-30-07, 47 p.

Tillitt, D.E., Papoulias, D.M., Whyte, J.J., and Richter, C.A., 2010, Atrazine reduces reproduction in fathead minnow (Pimephales promelas): Aquatic Toxicology, v. 99, no. 2, p. 149-159, [Also available at http://www.ncbi.nlm.nih.gov/pubmed/20471700].

U.S. Environmental Protection Agency, 2014, Fish Advisory Online: http:// fishadvisoryonline.epa.gov/General.aspx, Date accessed: August 5. 
Ungerer, J.R., and Thomas, P., 1996, Transport and accumulation of organochlorines in the ovaries of Atlantic croaker (Micropogonias undulatus): Marine Environmental Research, v. 42, no. 1-4, p. 167-171, [Also available at $h t t p: / / d x . d o i . o r g / 10.1016 / 0141-1136(95) 00050-X]$.

Van den Berg, M., Birnbaum, L., Bosveld, A.T.C., Brunstrom, B., Cook, P., Feeley, M., Giesy, J.P., Hanberg, A., Hasegawa, R., Kennedy, S.W., Kubiak, T., Larsen, J.C., van Leeuwen, F.X.R., Liem, A.K.D., Nolt, C., Peterson, R.E., Poelinger, L., Safe, S., Schrenk, D., Tillitt, D.E., Tysklind, M., Younes, M., Waern, F., and Zacharewski, T., 1998, Toxic equivalency factors (TEFs) for PCBs, PCDDs, PCDFs for humans and wildlife: Environmental Health Perspectives, v. 106, no. 12, p. 775-792, [Also available at http://www.ncbi.nlm.nih.gov/pubmed/9831538].

Van Eenenaam, J.P., and Dorsohov, S.I., 1998, Effects of age and body size on gonadal development of Atlantic sturgeon: Journal of Fish Biology, v. 53, p. 624-637.

Walker, M.K., and Peterson, R.E., 1991, Potencies of polychlorinated dibenzo-para-dioxin, dibenzofuran, and biphenyl congeners, relative to 2,3,7,8-tetrachlorodibenzo-para-dioxin, for producing early-life stage mortality in rainbow-trout (Oncorhynchus-mykiss): Aquatic Toxicology, v. 21, no. 3-4, p. 219-238, [Also available at http://dx.doi.org/10.1016/0166445x(91)90074-J].

Webb, M.A., Van Eenenaam, J.P., Doroshov, S.I., and Moberg, G.P., 1999, Preliminary observation on the effects of holding temperature on reproductive performance of female white sturgeon (Acipenser transmontanus, Richardson): Aquaculture, v. 176, p. 315-329.

Wildhaber, M.L., Papoulias, D.M., DeLonay, A.J., Tillitt, D.E., Bryan, J.L., Annis, M.L., and Allert, J.A., 2005, Gender identification of shovelnose sturgeon using ultrasonic and endoscopic imagery and the application of the method to the pallid sturgeon: Journal of Fish Biology, v. 67, no. 1, p. 114-132, [Also available at $h t t p: / / d x . d o i . o r g / 10.1111 /$ j.0022-1112.2005.00719.x] . 


\section{Appendix B. Database Fields and Descriptions for the Pallid Sturgeon Population Assessment Project}

Table B.1 Datasheets for Missouri River (habitat), fish, and supplemental information.

\begin{tabular}{|c|c|}
\hline \multicolumn{2}{|r|}{ Missouri River Datasheet } \\
\hline Database Field & Brief Description \\
\hline Year & Current sampling year \\
\hline FieldOffice & Collecting office \\
\hline Project & $\begin{array}{l}\text { 1(Population Assessment); 2(HAMP); 3(Chute); 4(Spring Rise); 5(Dalbey Bottoms); } \\
\text { 6(Catchability) }\end{array}$ \\
\hline Segment & River segment \\
\hline Season & ST (sturgeon); FC (fish community); HW (high-water) \\
\hline Bend & river bend number \\
\hline BendR/N & random or nonrandom \\
\hline BendRiverMile & top river mile of bend \\
\hline NetRiverMile & river mile where subsample collected \\
\hline Subsample & subsample number \\
\hline SubsampleR/N & random or nonrandom \\
\hline Pass & original or repeated pass (integer) \\
\hline UniqueID & unique number identifying subsample \\
\hline SetDate & date subsample was set \\
\hline GearType & standard gear or wild or experimental \\
\hline GearCode & gear used to collect fish \\
\hline Macro & Macrohabitat \\
\hline Meso & Mesohabitat \\
\hline Recorder & initials of biologist \\
\hline CheckedBy & initials of biologist \\
\hline Temp(c) & water temperature \\
\hline Turbidity & water turbidity \\
\hline Conductivity & water conductivity \\
\hline DO & water dissolved oxygen \\
\hline Distance & distance active gear was used (effort) or length of a MF lead \\
\hline Width & not typically used, but width of a gear \\
\hline StructureNumber & USACE number for training structure \\
\hline USGSGaugeCode & USGS number assigned to nearest gauge \\
\hline RiverStage & river stage from USGS gauge \\
\hline Discharge & river discharge from USGS gauge \\
\hline $\mathrm{U} 1$ & utility box \\
\hline $\mathrm{U} 2$ & utility box \\
\hline U3 & utility box \\
\hline $\mathrm{U} 4$ & utility box \\
\hline U6 & utility box \\
\hline U5 & utility box \\
\hline U7 & utility box \\
\hline Micro & microhabitat code \\
\hline MicroStructure & 1st digit in micro \\
\hline StructureFlow & 2nd digit in micro \\
\hline StructureMod & 3rd digit in micro \\
\hline SetSite1 & 4th digit in micro \\
\hline SetSite2 & 5th digit in micro \\
\hline SetSite3 & 6th digit in micro \\
\hline
\end{tabular}


Table B.1 Datasheets for Missouri River (habitat), fish, and supplemental information. - Continued

\begin{tabular}{|c|c|}
\hline \multicolumn{2}{|r|}{$\begin{array}{l}\text { Missouri River Datasheet (Continued) } \\
\end{array}$} \\
\hline Database Field & Brief Description \\
\hline StartTime & time gear deployed \\
\hline StartLatitude & latitude of start location \\
\hline StartLongitude & longitude of start location \\
\hline StopTime & time gear retrieved \\
\hline StopLatitude & latitude of stop location \\
\hline StopLongitude & longitude of stop location \\
\hline HabitatR/N & random or nonrandom \\
\hline 1_Depth & depth at start location \\
\hline 1_Velocity(bot) & bottom velocity at start location \\
\hline 1_Velocity(08) & velocity $80 \%$ depth at start location \\
\hline 1_Velocity(02or06) & velocity at 20 or $60 \%$ depth at start location (dependent on gear) \\
\hline 2_Depth & depth at midpoint of distance \\
\hline 2_Velocity(bot) & bottom velocity at midpoint \\
\hline 2_Velocity(08) & velocity $80 \%$ depth at midpoint \\
\hline 2_Velocity(02or06) & velocity at 20 or $60 \%$ depth at midpoint (dependent on gear) \\
\hline 3_Depth & depth at stop location \\
\hline 3_Velocity(bot) & bottom velocity at stop location \\
\hline 3_Velocity(08) & velocity at $80 \%$ depth at stop location \\
\hline 3_Velocity(02or06) & velocity at 20 or $60 \%$ depth at stop location (dependent on gear) \\
\hline Cobble & rating of cobble abundance \\
\hline Silt & percent substrate that is silt \\
\hline Sand & percent substrate that is sand \\
\hline Gravel & percent substrate that is gravel \\
\hline Organic & rating of organic abundance \\
\hline Comments & additional comments \\
\hline \multicolumn{2}{|r|}{ Fish Datasheet } \\
\hline Database Field & Brief Description \\
\hline Year & Current sampling year \\
\hline FieldOffice & Collecting office \\
\hline Project & $\begin{array}{l}\text { 1(Population Assessment); 2(HAMP); 3(Chute); 4(Spring Rise); 5(Dalbey Bottoms); } \\
\text { 6(Catchability) }\end{array}$ \\
\hline Segment & River segment \\
\hline Season & ST (sturgeon); FC (fish community); HW (high-water) \\
\hline Bend & river bend number \\
\hline BendR/N & random or nonrandom \\
\hline BendRiverMile & top river mile of bend \\
\hline UniqueID & unique number identifying subsample \\
\hline FishID & unique number identifying fish \\
\hline Panel/Hook & number of net panel or hook size \\
\hline Bait & letter code for fishing bait used \\
\hline Species & four digit alpha code \\
\hline Length(mm) & fish length \\
\hline Weight & fish weight \\
\hline Count & fish count per line \\
\hline Otolith & was otolith collected \\
\hline RaySpine & was ray or spine collected \\
\hline
\end{tabular}


Table B.1 Datasheets for Missouri River (habitat), fish, and supplemental information. - Continued

\begin{tabular}{|c|c|}
\hline \multicolumn{2}{|r|}{ Fish Datasheet (Continued) } \\
\hline Database Field & Brief Description \\
\hline Scale & was fish scale collected \\
\hline FloyTagprefix & letter code indicating what project a floy tag corresponds with \\
\hline FloyTagnumber & number of the tag \\
\hline FloyTagM/R & indicates whether tag was initial marking, recapture, double marked, etc \\
\hline Status & fish origin (that is hatchery, possibly wild, or unknown) \\
\hline YearClass & year class of a hatchery produced fish \\
\hline SFL & length at time of stocking of a hatchery reared fish \\
\hline SWt & weight at time of stocking \\
\hline StockingDate & date hatchery reared fish was stocked \\
\hline StockingYear & year hatchery reared fish was stocked \\
\hline Site & stocking site \\
\hline Source & name of the hatchery where stocked fish was reared \\
\hline \multicolumn{2}{|r|}{ Supplemental Datasheet } \\
\hline Database Field & Brief Description \\
\hline Year & Current sampling year \\
\hline FieldOffice & Collecting office \\
\hline Project & $\begin{array}{l}\text { 1(Population Assessment); 2(HAMP); 3(Chute); 4(Spring Rise); 5(Dalbey Bottoms); } \\
\text { 6(Catchability) }\end{array}$ \\
\hline Segment & River segment \\
\hline Season & ST (sturgeon); FC (fish community); HW (high-water) \\
\hline Bend & river bend number \\
\hline BendR/N & random or nonrandom \\
\hline BendRiverMile & top river mile of bend \\
\hline UniqueID & unique number identifying subsample \\
\hline Subsample & subsample number \\
\hline SubsampleR/N & random or nonrandom \\
\hline Pass & original or repeated pass (integer) \\
\hline FishID & unique number identifying fish \\
\hline SetDate & date subsample was set \\
\hline Gear & gear used to collect \\
\hline GearS/W & standard gear or wild or experimental \\
\hline Recorder & initials of biologist \\
\hline CheckedBy & initials of biologist \\
\hline TagNumber & number of a PIT tag \\
\hline $\mathrm{PitR} / \mathrm{N} / \mathrm{Z}$ & indicates whether PIT tag was initial marking, recapture, or malfunctioning tag detected \\
\hline $\mathrm{CWTY} / \mathrm{N}$ & coded wire tag present or not \\
\hline DanglerY/N & dangler tag present or not \\
\hline ScuteLocation/N & scute removed on left, right, dorsal, or no scute removed \\
\hline Scute\# & scute number removed from the anterior \\
\hline $\mathrm{ELH} / \mathrm{V} / \mathrm{X}$ & elastomer left orientation (horizontal, vertical, undetermined) \\
\hline
\end{tabular}


Table B.1 Datasheets for Missouri River (habitat), fish, and supplemental information. - Continued

\begin{tabular}{|c|c|}
\hline \multicolumn{2}{|r|}{ Supplemental Datasheet (Continued) } \\
\hline Database Field & Brief Description \\
\hline ELColorN/X & elastomer left color code, tag not present, or undetermined \\
\hline $\mathrm{ERH} / \mathrm{V} / \mathrm{X}$ & elastomer right orientation (horizontal, vertical, undetermined) \\
\hline ERColorN/X & elastomer right color code, tag not present, or undetermined \\
\hline GeneticY/N & genetic sample taken or not \\
\hline GeneticsVial\# & vial number of genetics sample if taken \\
\hline Head & tip of the rostrum to the posterior margin of the operculum \\
\hline SnouttoMouth & tip of the rostrum to the anterior midline of the mouth \\
\hline Inter & tip of the rostrum to the anterior point of insertion of the ROB \\
\hline MouthWidth & widest measurement on the outer edge of the lips \\
\hline M_IB & $\begin{array}{l}\text { (mouth to inner barbel) anterior point of insertion of the RIB to the anterior } \\
\text { midline of the mouth }\end{array}$ \\
\hline L_OB & (left outer barbel) anterior point of insertion to the lip \\
\hline L_IB & (left inner barbel) anterior point of insertion to the lip \\
\hline R_IB & (right inner barbel) anterior point of insertion to the lip \\
\hline R_OB & (right outer barbel) anterior point of insertion to the lip \\
\hline Anal & number of rays at base of the anal fin \\
\hline Dorsal & number of rays at base of the dorsal fin \\
\hline OthertagInformation & additional tag information \\
\hline Sex & sex of fish if known \\
\hline Stage & reproductive stage of fish if known \\
\hline PallidLocation & current location of pallid (released, taken to hatchery, etc) \\
\hline PictureY/N & voucher pictures taken or not \\
\hline Recapture & was fish a recapture or not \\
\hline Characterindex & calculated CI score \\
\hline MorphometricCharacterIndex & calculated MCI score \\
\hline
\end{tabular}

ISSN 2331-1258 (online)

http://dx.doi.org/10.3133/of20151226 

